


\section{Índice}

Sociologia do trabalho, serviços e avaliação do desempenho no trabalho: notas de reflexão

Paulo Pereira de Almeida

Quando Tudo se Desmorona: Um Contributo Literário à

(Inter)Historicidade

Fernanda Santos Benedito

Norbert Elias e a configuração: um conceito interdisciplinar

Pedro Candeias

Ecos de um futuro passado: pos-memórias da nanotecnologia no cinema e nos videojogos

Rui Vieira Cruz

Metamorfoses na política, valores empresariais e exercício profissional em saúde em Portugal

Ana Paula Marques e Iallê Falleiros

O passado por dentro do presente: Guerra Colonial portuguesa e as reescritas da memória cultural

Doris Wieser e Luciana Moreira

\section{Recensões}

SILVA, Manuel Carlos, LIMA, Maria Luísa, SOBRAL, José Manuel, ARAÚJO, Helena, RIBEIRO, Fernando Bessa (orgs.) (2016) Ana Maria Brandão

Fernando Matos Rodrigues, António J. Cerejeira Fontes, Manuel Carlos Silva e André Cerejeira Fontes (coord.) (2016). A Cidade da Participação: Projeto de arquitetura básica participada na Ilha da Bela Vista 105 Fernando Bessa Ribeiro 
Almeida, Paulo Pereira de - Sociologia do trabalho, serviços e avaliação do desempenho no trabalho: notas de reflexão. Configurações, vol. 19, 2017, pp. 3-18

\title{
Sociologia do trabalho, serviços e avaliação do desempenho no trabalho: notas de reflexão
}

\author{
PAULO PEREIRA DE ALMEIDA*
}

Instituto Universitário de Lisboa

\begin{abstract}
Resumo
Este artigo lida com as problemáticas do trabalho e do emprego e com a necessidade de introduzir uma avaliação baseada em critérios múltiplos para o desempenho dos trabalhadores. É uma constatação importante o facto de grande parte do trabalho nos serviços se desenvolver numa antinomia em relação aos modelos industriais, podendo argumentar-se que a terciarização das atividades económicas modifica o tipo de qualificações e de competências exigidas aos trabalhadores no quadro das dinâmicas do trabalho e do emprego das últimas quatro décadas nas sociedades capitalistas avançadas. No presente artigo, discutem-se, em estilo de ensaio, as dinâmicas e paradigmas de análise do trabalho e da avaliação dos trabalhadores em organizações complexas, propondo-se esquemas de análise e ilustrando-se estes fenómenos com estatísticas recentes.
\end{abstract}

Palavras-chave: trabalho, serviço, competências, organizações complexas, avaliação do desempenho.

\footnotetext{
Abstract

Sociology of work, services and performance appraisal: some reflections and remarks This article deals with the problems of work and employment and the need to introduce a multi-criteria-based assessment for the performance of workers. It is an important finding that much of the work in services is developed in contradiction to industrial models, and one can argue that the service growth of economic activities modifies the type of qualifications and skills required of workers in labour and employment dynamics over the past four decades in advanced capitalist societies. In this article, we discuss the dynamics and analysis of the work paradigms and worker assessment in

* ISCTE-IUL, Departamento de Sociologia, Investigador e Sociólogo do Trabalho; E-mail: paulo.pereira. almeida@iscte.pt
} 
complex organisations, proposing analytic schemes and illustrating these phenomena with recent statistics.

Keywords: work, services, skills, complex organisations, performance appraisal.

\section{Résumé \\ La sociologie du travail, les services et la performance au travail : quelques réflexions et remarques}

Cet article porte sur les questions du travail et de l'emploi et sur la nécessité d'introduire une évaluation fondée sur des critères multiples en matière de performance des employés. Il s'agit d'un constat majeur le fait que plupart du travail dans les services est développé dans une antinomie par rapport aux modèles industriels, de sorte qu'il est possible d'affirmer que la tertiarisation des activités économiques modifie le type de qualifications et de compétences requises des travailleurs, dans le cadre des dynamiques du travail et de l'emploi des quatre dernières décennies dans les sociétés capitalistes avancées. Dans cet article, nous discutons les dynamiques et les paradigmes d'analyse du travail et de l'évaluation des travailleurs dans des organisations complexes, en proposant des schémas d'analyse et en illustrant ces phénomènes avec des statistiques récentes.

Mots-clés : travail, services, compétences, organisations complexes, évaluation de la performance.

\section{Introdução}

O presente artigo foca-se num "estado de arte" sobre conceitos relevantes no domínio dos serviços e da avaliação do desempenho no trabalho. Recorremos a técnicas de pesquisa estatística de alguns indicadores e fazemos uso de alguns dos recentes (e clássicos) argumentos no debate acerca da "terciarização" das economias e do trabalho e de alguns "revivalismos" na análise do carácter industrial das atividades humanas produtivas. É, pois, uma constatação importante o facto de grande parte do trabalho nos serviços se desenvolver numa antinomia em relação aos modelos industriais (Almeida, 2005, 2011, 2012a). Muito embora se verifiquem elementos de constância relativamente ao paradigma industrial, a rapidez das operações que legitimava a exploração das qualidades dos sistemas e das máquinas no período industrial tornou-se desfasada relativamente às exigências de iniciativa, de inteligência prática, de comunicação com os colegas e de diálogo com os clientes que, atualmente, consubstanciam grande parte das atividades de trabalho humano (Macdonald, 1995; Sennett, 2009).

Pode, assim, argumentar-se que a "terciarização" das atividades económicas modifica o tipo de competências exigidas aos trabalhadores, sendo comum associar esta "lógica de serviço" a uma centralidade particular do "modelo da competência" (Almeida, 2012b; Gadrey e Zarifian, 2002). Na ótica de Gadrey e Zarifian (2002), o que a noção de competência designa é 
uma nova unidade entre o trabalho e o trabalhador, unidade na qual o trabalho reincorpora o indivíduo e em que se procura mobilizar e prolongar os saberes e a inteligência imaginativa possuídos ou coconstruídos por esse indivíduo. Trata-se, no seu raciocínio, de recrear as etapas do trabalho nas empresas de serviço, que se iniciam com uma fase de (re)conhecimento e de interpretação das necessidades do cliente para terminarem com a produção efetiva de um serviço (idem, ibidem).

Não negamos, contudo, que é uma ideia comummente aceite que vivemos numa economia dos serviços (e, não propriamente, do serviço): as economias são descritas a partir de uma acrescida importância das atividades terciárias (medidas pelo seu peso no emprego, no produto, ou no valor acrescentado). É a este crescimento que vulgarmente se refere o termo "terciarização", fenómeno associado a um movimento lento e profundo de aumento da importância do lugar ocupado pelas atividades terciárias no conjunto do sistema produtivo, sendo que este último segue, por vezes, em paralelo com a evolução de profissões e de empregos de natureza terciária nas empresas industriais. Mas, e na verdade, as preocupações dos autores contemporâneos têm-se deslocado para a análise das lógicas de serviço (i.e., dos tipos de produtores e de destinatários em interação com as formas de organização do trabalho), designadamente nas suas dimensões relacional e simbólica (Almeida, 2005, 2012a). Além disso, esta mudança de paradigma é também marcada por uma reflexão acerca dos diferentes "produtos-serviço" terciários nos aspetos atinentes à sua (i)materialidade e aos saberes intelectuais e às capacidades humanas aplicadas aos atos de trabalho (idem, ibidem).

Adotando a segunda alternativa, observamos que, na sua essência, a medida sobre o efeito direto de um serviço não releva somente do momento exato em que este é "consumido". Esta observação é particularmente importante para os "serviços puros" dada a forte componente de trabalho cujos efeitos não podem fazer sentir-se senão a longo prazo (ensino, investigação, saúde...). Neste caso, os conceitos de produto e de produtividade perdem a sua pertinência na medida em que o resultado final é, na maior parte, "desligado" do trabalho imediato efetuado. Esta evidência é hoje igualmente válida para os serviços consumidos pelas empresas industriais, colocando-se, por exemplo, questões relevantes, tais como: de que forma se pode medir plenamente o acréscimo de eficácia trazido por uma consultora de ergonomia ou como é que se pode avaliar os impactos de uma intervenção de consultoria na eficácia de uma empresa?

\section{Dinâmicas do trabalho e do emprego em sociedades modernasDu-}

rante a segunda metade do século XX, a estrutura da produção e do emprego transformou-se na generalidade dos países do mundo, tendo sido este um movimento coincidente com a disseminação das atividades de trabalho relacionadas 
com os serviços. Todavia, esta constatação acerca da diferenciação sectorial das empresas tem dado lugar a críticas acerca da utilidade da definição de limites ou de fronteiras inter e intrassectoriais. São, justamente, as explicações estatísticas convencionais acerca da "terciarização" das sociedades que nos reconduzem à consideração das suas limitações explicativas (Almeida, 2011, 2012a). Em termos puramente estatísticos, é de salientar a importância do "sector terciário", com a crescente importância do número de trabalhadores ativos neste sector de atividade, com valores próximos dos 70\%, na União Europeia, e superiores a 80\%, nos Estados Unidos da América, em 2010 (quadro 1)

\section{Quadro 1}

Percentagem da população ativa nos serviços em relação ao total

\begin{tabular}{|l|c|c|c|c|}
\hline & 1980 & 1990 & 2000 & 2010 \\
\hline União Europeia & 52,9 & 60,90 & $\begin{array}{c}\text { Não } \\
\text { disponível }\end{array}$ & 69,6 \\
\hline $\begin{array}{l}\text { Estados Unidos } \\
\text { da América }\end{array}$ & $\begin{array}{c}65,9 \\
\text { Não } \\
\text { disponível }\end{array}$ & $\begin{array}{c}\text { Não } \\
\text { disponível }\end{array}$ & 61,9 & 67,20 \\
\hline
\end{tabular}

Fonte: OCDE (2011). Cálculos do autor.

$\mathrm{Na}$ verdade, o desenvolvimento do terciário resulta de fenómenos económicos e sociais heterogéneos e desdobra-se em atividades extremamente diversas. No geral, e perante uma análise da "terciarização" e do "desenvolvimento do terciário", existe a necessidade de uma explicitação mais precisa do termo, no sentido de dar conta da sua segmentação e diferenciação interna. É assim que o "sector terciário" se transforma numa realidade difícil de delimitar e de apreender (Almeida, 2011, 2012a).

Acresce, como já vimos, que o emprego seletivo da sociedade pós-industrial substitui agora o trabalho integrador da sociedade industrial: por um lado, as grandes unidades de produção taylorizadas que empregavam trabalhadores pouco qualificados do início do século XX - e em que a velocidade de criação de novos empregos superava a destruição dos empregos antigos, em paralelo com um aumento da população ativa - cedem lugar a novos tipos de empregos, criados em serviços públicos e em pequenas ou médias empresas dos serviços, apresentando um carácter volátil acrescido; por outro lado, o aumento da importância económica e social das atividades terciárias faz-se, em muitos casos, pela industrialização de sectores de atividade já existentes - como são os 
casos da banca, dos seguros e da grande distribuição-comercialização - e pelas concentrações destinadas a mobilizar capitais para atividades em forte expansão - como são os casos dos circuitos de grande distribuição e das centrais de compras (Iribarne, 1993).

Depois do início da década de 1980, a abordagem do "dualismo das qualificações" no terciário é substituída por uma conceção dualista mais subtil que diz respeito ao estatuto dos empregos e às formas de gestão da mão-de-obra: estima-se que uma fração maioritária dos empregos dos serviços faça parte de um "segmento secundário" do mercado de trabalho, constituído por empregos de estatuto precário, cuja existência e manutenção dependem da conjuntura económica $^{1}$. É, precisamente, neste enquadramento que as preocupações dos autores contemporâneos se têm deslocado para a análise das lógicas de serviço (i.e., dos tipos de produtores e de destinatários em interação com as formas de organização do trabalho), designadamente nas suas dimensões relacional e simbólica.

Esta mudança de paradigma é também marcada por uma reflexão acerca dos diferentes "produtos-serviço" terciários nos aspetos atinentes à sua (i)materialidade e aos saberes intelectuais e às capacidades humanas aplicadas aos atos de trabalho (Almeida, 2009, 2011, 2012a). Aliás, e perante estas constatações acerca do esgotamento das explicações mais clássicas para o crescimento do terciário, existem, atualmente, e a nosso ver, duas opções alternativas: aceitar a lógica do débito industrial e da sua contabilidade ou, a contrario, interrogar a pertinência e a validade das medidas da produtividade. Reconhecemos, naturalmente, que esta questão não é nova, mas acreditamos que se coloca com maior acuidade no sector dos serviços (Almeida, 2005, 2012a). Adotando a segunda alternativa, observamos que, na sua essência, a medida sobre o efeito direto de um serviço não releva somente do momento exato em que este é "consumido". Esta observação é particularmente importante para os "serviços puros" dada a forte componente de trabalho cujos efeitos não podem fazer sentir-se senão a longo prazo (ensino, investigação, saúde...). Neste caso em concreto, os conceitos de produto e de produtividade perdem a sua pertinência na medida em que o resultado final está, na sua maior parte, "desligado" do trabalho imediato efetuado (Almeida, 2011, 2012a).

Semanticamente, o conceito de "emprego" corresponde ao resultado da celebração de um contrato entre duas partes: um empregado e um empregador. $\mathrm{Na}$ legislação portuguesa referente ao trabalho e à gestão dos recursos humanos

1 Esta heterogeneidade numérica é ainda complementada, segundo Gadrey (1999), pelo carácter de especificidade dos sistemas de emprego terciários, baseada em duas hipóteses complementares: primeiro, é nos serviços que proliferam as formas de gestão de mão-de-obra "flexíveis" que se tornarão relativamente dominantes na organização do trabalho do final do século XX; segundo, o movimento de terciarização do mercado de trabalho industrial é mais importante do que o movimento de "industrialização" dos sistemas de emprego terciários. 
das empresas e das organizações (concretamente, no seu Código do Trabalho), a noção de emprego surge associada à celebração de um contrato de trabalho: um contrato pelo qual um trabalhador se obriga, mediante retribuição, a prestar a sua atividade a outra ou outras pessoas, sob a autoridade e direção destas. O emprego está, pois, associado a uma transação comercial com dois intervenientes: (1) por um lado, o empregador, que concebe uma atividade produtiva, podendo esta ser encarada em sentido lato e incluir objetivos de gerar lucros, criar emprego e contribuir para a sustentabilidade do planeta, atentas as formas éticas de organizar e de gerir o trabalho, bem como a Responsabilidade Social das Empresas (RSE); e, (2) por outro lado, o trabalhador que deve contribuir com o seu trabalho, tendo como contrapartida o pagamento de um salário (Almeida, 2005).

Para além de o “emprego" ter como contrapartida o pagamento de um salário, no século XXI, tem vindo a ganhar uma considerável importância a noção de “emprego digno”. Para a Organização Internacional do Trabalho (2001), um emprego digno corresponde: (1) a um emprego produtivo e seguro; (2) que assegura o respeito pelos direitos laborais; (3) que fornece um rendimento adequado; (4) que assegura a proteção social; e (5) que inclui diálogo social, liberdade sindical, negociação coletiva e participação.

A atenção dada à qualidade do emprego tem, pois, implicações na gestão de recursos humanos e na relação dos trabalhadores com as organizações, em geral, e com as empresas, em particular. Parte-se do princípio de que existe uma relação entre o salário de eficiência e os custos de rotação da mão-de-obra: o facto de as empresas terem interesse em "reter" os seus trabalhadores torna-se numa importante característica do emprego (Almeida, 2005, 2012a). Esta faz-se, então, de acordo com duas alternativas: (1) a empresa pode deixar sair os seus empregados propondo-lhes um salário baixo em relação ao salário do mercado, o que eleva os custos com a rotação da mão-de-obra, embora diminua os custos diretos do trabalho; ou (2) a empresa pode reter os seus empregados oferecendo-lhes um salário superior ao do mercado, dissuadindo-os, desta forma, da procura de um emprego noutras empresas, anulando os custos de rotação da mão-de-obra, muito embora elevando, dessa forma, os custos diretos do trabalho ${ }^{2}$.

Ao conceito de emprego também se encontra associado o conceito de "qualificação", sendo de reter que, com a nova divisão do trabalho nas sociedades

2 A legislação portuguesa (Código do Trabalho) consagra explicitamente o direito à igualdade no acesso ao emprego e no trabalho, salientando que: (1) todos os trabalhadores têm direito à igualdade de oportunidades e de tratamento no que se refere ao acesso ao emprego, à formação e promoção profissionais e às condições de trabalho; e (2) nenhum trabalhador ou candidato a emprego pode ser privilegiado, beneficiado, prejudicado, privado de qualquer direito ou isento de qualquer dever em razão, nomeadamente, de ascendência, idade, sexo, orientação sexual, estado civil, situação familiar, património genético, capacidade de trabalho reduzida, deficiência, doença crónica, nacionalidade, origem étnica, religião, convicções políticas ou ideológicas e filiação sindical. 
contemporâneas, a rápida evolução da técnica relega para plano secundário a antiga experiência do "ofício" e a aprendizagem de tipo "artesanal”. As teorias do salário de eficiência, de meados da década de 1980, alargam as dimensões até aí consideradas para o fator trabalho: anteriormente medido apenas no seu volume, o trabalho humano é agora caracterizado pela sua intensidade e pela sua qualidade. Associadas às formas de classificação que tornam o trabalho e o trabalhador "utilizáveis", as escalas de qualificação e as classificações dos empregos permitem especificar - a partir do exterior das empresas - a relação de subordinação e dotar a força de trabalho de mobilidade (idem, ibidem) ${ }^{3}$.

Durante a década de 1980 e seguintes, será, justamente, num sistema de produção mais instável, forçado a adaptar-se às flutuações da procura (tanto em termos de quantidade, como em termos de renovação da gama de produtos e de serviço oferecidos) que a noção de "polivalência" ganha uma utilidade considerável nas políticas de gestão de recursos humanos (idem, ibid.). Nesta conjuntura, toma-se como verdadeiro que o desenvolvimento da polivalência constitui uma vantagem real para as empresas através da redução de efetivos, da flexibilidade do coletivo de trabalho e de uma maior homogeneidade das qualificações. E, apesar da natural resistência dos trabalhadores à polivalência, esta melhorou as suas condições de trabalho e alargou as suas capacidades qualificantes contribuindo para que, no princípio da década de 1990, começasse a ganhar forma o entendimento de que a qualificação se encontra relacionada com a capacidade de gerir o imprevisto, tornando a adaptabilidade num fator essencial para a caracterização do emprego nas últimas décadas (Almeida, 2012b).

Frequentemente associa-se as "habilitações literárias" às qualificações, designadamente para o momento de entrada no mercado de trabalho, pelo que às dinâmicas do emprego nas sociedades capitalistas avançadas também podemos associar as dinâmicas da qualificação da mão-de-obra presentes nas atuais políticas públicas de qualificação. No caso de Portugal, esta dinâmica é evidente se analisarmos e compararmos os dados referentes às habilitações literárias dos trabalhadores portugueses nos anos de 2000 e de 2010, sendo clara a tendência para o aumento da percentagem de trabalhadores com curso superior e ensino secundário em percentagem dos empregos totais disponíveis no mercado de trabalho (quadro 2).

\footnotetext{
3 Nesta perspetiva, o movimento de cada trabalhador no chamado "espaço" da qualificação já não é regulado pelo conjunto dos próprios trabalhadores, que anteriormente se organizavam de modo a controlar a sua própria sucessão e concorrência recíprocas: a qualificação do trabalho visa um conjunto de competências que são reconhecidas ao trabalhador, as quais são remuneradas de acordo com os diferentes empregos em que este se encontra (Almeida, 2011).
} 


\section{Quadro 2}

Habilitações literárias dos trabalhadores portugueses (2000 e 2010)

\begin{tabular}{l|c|c|} 
& 2000 & 2010 \\
\hline $\begin{array}{l}\text { Trabalhadores com curso superior e ensino se- } \\
\text { cundário em \% dos empregos }\end{array}$ & $20,8 \%$ & $35,95 \%$ \\
\hline $\begin{array}{l}\text { trabalhadores com habilitações ao nível do en- } \\
\text { sino básico até ao } 3^{\circ} \text { ciclo em \% dos empregos }\end{array}$ & $79,2 \%$ & $61,1 \%$ \\
\hline
\end{tabular}

Fonte: Instituto Nacional de Estatística (2000-2010). Dados referentes ao $4{ }^{\circ}$ trimestre. Cálculos do autor.

Associado aos conceitos de "emprego" e "qualificação” encontra-se também o de conceito de “empregabilidade”. Por norma, a empregabilidade é descrita na literatura especializada como estando relacionada com: (1) a capacidade dos trabalhadores de encontrarem um emprego; (2) a capacidade de se manterem nesse emprego; e (3) a capacidade de os trabalhadores tornarem as suas competências e qualificações úteis aos atuais e potenciais empregadores. A questão da oferta de emprego pelo lado das empresas e da procura de emprego pelo lado dos trabalhadores coloca o problema do potencial desajustamento entre essa oferta e procura de emprego. Se a caracterização do sistema educativo como ineficaz é, para alguns, o corolário lógico da constatação de falta de qualificações disponíveis no mercado de trabalho, para as empresas e as organizações, a falta de mão-de-obra pode também ser uma consequência das suas políticas de gestão interna. Na verdade, estas nem sempre possuem a capacidade ou os meios para pôr em prática um sistema de formação, o que se torna especialmente pertinente se pensarmos nas empresas de pequena ou de média dimensão, dada a amplitude limitada dos seus meios financeiros ou das necessidades de mão-de-obra (Almeida, 2005, 2012a).

Se considerarmos as dinâmicas hodiernas do emprego nas sociedades contemporâneas, concluímos que é a partir da década de 1980 que a ideia de flexibilidade se começa a disseminar nas empresas, encarada como forma de gestão da força de trabalho baseada no uso crescente de formas de trabalho flexíveis ou ditas “atípicas". Por um lado, cresce a utilização de trabalho a tempo parcial, do trabalho temporário, dos contratos de duração determinada e da subcontratação; por outro lado, decresce, por comparação, a utilização de contratos de trabalho a tempo inteiro, sem uma duração temporalmente limitada. Nesta lógica, a flexibilidade pode ser entendida, de uma forma simples, como o movimento que se afasta das disposições estandardizadas nas relações industriais relacionadas com horários de trabalho, relações laborais, segurança social, entre outras. Neste sentido, a flexibilidade surge como o reflexo das mudanças: 
(1) nas práticas empresariais; (2) na organização do trabalho por via da especialização flexível; e (3) na sociedade, em geral, por via da pluralização das classes sociais, de novos estilos de vida e da procura de novos sistemas de produção como resposta aos gostos volúveis dos consumidores no quadro de uma sociedade de serviços e do serviço (idem, ibidem).

Das dinâmicas do emprego e da qualificação em Portugal fazem parte, ainda, portanto, os processos de alteração gradual dos vínculos contratuais dos trabalhadores portugueses, com uma tendência acentuada, no mercado de trabalho e nos stocks de empregos disponíveis, para o aumento dos trabalhadores com contrato a termo (a prazo) em percentagem dos empregos (quadro 3).

Quadro 3

Tipos de vínculo contratual dos trabalhadores portugueses

\begin{tabular}{|l|l|l|l|} 
& \multicolumn{1}{|c|}{1990} & \multicolumn{1}{c|}{2000} & 2010 \\
\hline $\begin{array}{l}\text { Trabalhadores com contrato } \\
\text { sem termo (efetivos) em \% dos } \\
\text { empregos }\end{array}$ & $78 \%$ & $79,4 \%$ & $77,5 \%$ \\
\hline $\begin{array}{l}\text { Trabalhadores com contrato } \\
\text { a termo (a prazo) em \% dos } \\
\text { empregos }\end{array}$ & $16,2 \%$ & $14,4 \%$ & $18,8 \%$ \\
\hline $\begin{array}{l}\text { Outras formas de contrato em \% } \\
\text { dos empregos }\end{array}$ & $5,8 \%$ & $6,2 \%$ & $3,8 \%$ \\
\hline
\end{tabular}

Fonte: Instituto Nacional de Estatística (1990-2010). Dados referentes ao $4^{\circ}$ trimestre.Cálculos do autor.

Já durante a década de 1990, a noção de "flexibilidade" torna-se, então, quase universal, transformando-se num objetivo estratégico para a gestão de recursos humanos. Este fenómeno tem duas explicações (Almeida, 2005, 2011, 2012a): (1) é colocada uma ênfase na redução de custos unitários de produção quer através do afastamento de trabalhadores sem contribuição direta para a produção, quer através da redução dos custos da mão-de-obra diretamente produtiva; e (2) a flexibilidade corresponde agora à capacidade da empresa para ajustar a dimensão e o mix dos inputs do trabalho às mudanças na procura de produtos de modo a que os custos do trabalho "excedentário" não sejam suportados pela organização. 


\section{Trabalho moderno e avaliação dos trabalhadores em organizações complexas}

Sendo uma das mais antigas formas de ocupação e de dignidade humana, o trabalho é, hoje mais do que nunca, um aspeto estruturante na constituição psicológica das pessoas e no ciclo das suas atividades diárias. Ter um emprego constitui um elemento central para se preservar o respeito por si próprio (Giddens, 2011). Além disso, o trabalho constitui uma instituição social separada das restantes (por exemplo, da família e da religião) e também separada em termos de espaço, de tempo e de cultura, sendo o tempo de trabalho e o tempo de não-trabalho um aspeto estruturante das economias capitalistas avançadas. $\mathrm{Na}$ verdade, e se considerarmos as empresas nas sociedades modernas, ao trabalho corresponde uma atividade desenvolvida no quadro de organizações de serviço em que uma significativa parte do tempo das pessoas é dedicada à interação com sistemas tecnológicos que incluem uma logística relacional e uma informação acerca das possibilidades de coprodução de soluções orientadas para o cliente-utente (Almeida, 2012a; Tyson, 2015).

Para além destas definições do trabalho - das quais se destaca o seu carácter omnipresente no sistema ocupacional das sociedades capitalistas avançadas - existem, ainda, outras características do trabalho humano muito relevantes, a saber (Giddens, 2011): (1) o pagamento de um salário em dinheiro, sendo esta a principal fonte de rendimento das pessoas para fazerem face às suas necessidades de subsistência; sem salário, ou com níveis elevados de desemprego, as ansiedades quotidianas tendem a aumentar; (2) o acesso a uma variedade de ambientes diferentes do ambiente doméstico, no qual os indivíduos podem também estabelecer contactos sociais, criar laços de amizade e ter a oportunidade de partilhar as suas atividades com outros; (3) a estruturação temporal para o exercício de um conjunto de atividades produtivas essenciais à sobrevivência das sociedades através das energias despendidas pelas pessoas no seu emprego fixo; e (4) a identidade social estável oferecida pela existência de um trabalho e pelo desempenho de funções de utilidade social e produtiva, essenciais para a estabilidade positiva dos indivíduos e para a coesão da sociedade como um todo.

Nestas dinâmicas das sociedades capitalistas avançadas, o trabalho humano, a questão do seu valor e da sua avaliação adquirem uma centralidade e uma importância acrescidas. O trabalho é, naturalmente, um elemento central para o sentimento de equidade e de justiça dos trabalhadores nas organizações e empresas. Além disso, o contexto atual das sociedades capitalistas avançadas está marcado pela "mundialização", o que também afeta a distribuição mundial do trabalho. Aliás, e como é sabido, com o recurso massivo à Internet e à generalidade das tecnologias de informação e de comunicação, o espaço e o tempo deixam de ser relevantes: (1) a acompanhar a mundialização encontramos, então, uma tendência para a desterritorialização, designadamente nas 
condições objetivas de trabalho e de vida dos trabalhadores; e (2) uma parte significativa do trabalho contemporâneo desenvolve-se agora no contexto de uma servicialização orientada para os fluxos quantitativos em organizações e empresas onde o fator tecnológico é, portanto, bastante relevante.

Na perspetiva de Gadrey e Zarifian (2002), a organização das modernas empresas de serviço - uma realidade organizativa transversal aos três sectores económicos clássicos - pode enquadrar-se na emergência de duas grandes evoluções. A primeira destas mutações é, segundo os autores, localizável no início da década de 1980 e diz respeito à transformação dos princípios organizativos das empresas industriais, as quais procuravam engendrar formas de produzir flexíveis. Semelhantes opções destinavam-se a responder a dois tipos de ensejos: por um lado, conciliar os princípios de base das economias de escala e das economias de débito com produtos diversificados e com elevadas taxas de renovação dos seus produtos e serviços e, por outro lado, captar uma clientela que continuava a ser construída sobretudo a partir da oferta, não obstante a já acentuada tendência para uma "produção simbólica do cliente" a partir das técnicas de marketing. A segunda evolução diz respeito a um conceito central no pensamento dos autores: o da acentuação do valor de uso ${ }^{4}$.

Seguindo esta linha de pensamento, a análise das mutações atuais no conteúdo do trabalho - e das novas questões que se colocam na perspetiva da sua produtividade - emerge de uma tríade de noções (Zarifian, 2001, 2009): o "acontecimento", a "comunicação" e o "serviço". Particularmente no tocante aos "acontecimentos" - conceito que Zarifian considera central para analisar o trabalho moderno - este é um fenómeno que surge de forma imprevista, não programada, mas importante para o sucesso da atividade produtiva (é em torno do acontecimento que se desenrolam as intervenções humanas mais complexas e essenciais, mediadas pelos suportes comunicacionais). A importância atribuída pelo autor a esta noção pode ser melhor compreendida no momento em que se estabelece a distinção, do ponto de vista da performance esperada, entre qualidade "de" serviço e qualidade "do" serviço: (1) a qualidade "de" serviço apresenta-se como uma noção consistente, em particular nas perspetivas logísticas; exprime-se no cumprimento de um prazo, na observação do valor de serviço, i.e., nos instrumentos que permitem objetivar os elementos factuais e que foram introduzidos na relação com o destinatário; (2) ao invés, a qualidade “do" serviço apresenta-se como uma noção de difícil perceção - exprime a forma como o produto se inscreve na prática do destinatário e modifica a sua

4 No raciocínio de Zarifian (2002, 2009), entende-se como “produção de serviço" o processo que desemboca na transformação das condições de atividade, ou mesmo das disposições para ação, de um indivíduo ou de um grupo de indivíduos. Este constitui o ponto de partida e um dos princípios integrados na conceção estrutural das práticas organizativas que, nesta conceção de empresa de serviço, integram ex ante e ex post os efeitos úteis que esses bens produzem nas condições de atividade de um determinado destinatário (cliente, utente, por exemplo) 
situação, ou seja, as condições de produção, tratando-se de uma outra empresa, e as condições de vida, tratando-se de um cliente/utilizador.

Também a tomada de decisão pelos trabalhadores, quando é produzida, situa-se num quadro interequipas, mas as tarefas estritamente estandardizadas deste sistema de produção restringem a autonomia do indivíduo. Embora proporcionem maior diversidade do que os sistemas resultantes do taylorismo e do fordismo, a verdade é que essa diversidade das organizações estruturadas de acordo com a lean production se torna claramente limitada em comparação com os modelos produzidos pela teoria comportamental. De acordo com a tipologia proposta por Coutrot (1998), emergem, assim, novas lógicas de participação dos trabalhadores na vida empresarial que se repartem por cinco modelos principais: (1) o modelo americano de recursos humanos; (2) o modelo sociotécnico sueco; (3) o toyotismo ou produção magra japonesa; (4) a especialização flexível à italiana; e (5) a produção alemã diversificada e de qualidade.

O modelo americano de recursos humanos emerge do sentimento de crítica dos responsáveis pela gestão de recursos humanos norte-americanos em relação à expansão da burocracia e à impessoalidade dos modelos de produção fordistas. Trata-se de encontrar uma aplicação mais flexível para o modo de organização taylorista-fordista, assente numa elevada flexibilidade na distribuição das tarefas entre os trabalhadores ou numa política de remuneração mais individualizada.

O modelo sociotécnico sueco baseia-se nas reações dos trabalhadores ao travail en miettes nos primórdios da década de 1960, culminando com as experiências de Uddevalla (Suécia) durante as décadas de 1980 e de 1990. Fundamentalmente, o que este modelo de organização do trabalho preconiza é uma rutura com a lógica taylorista de decomposição das tarefas, baseada numa economia dos tempos, para a substituir por uma lógica de inteligência da produção em que o trabalhador pode antecipar reflexivamente a forma correta de assemblagem de um produto (no caso da fábrica da Volvo, dos modelos $940 \mathrm{e}$ posteriores, aí fabricados após um interregno de produção entre 1993 e 1996). O toyotismo ou produção magra japonesa baseia-se na ideia fundamental de fluidez na produção, sem uma contestação direta dos princípios fundamentais de base taylorista-fordista, mas com uma inflexão fundamental que consiste em considerar fundamental a mobilização das capacidades e da inteligência individual e coletiva dos trabalhadores para a resolução de problemas pontuais na cadeia produtiva. Os princípios de redução de stocks, de melhoria permanente (kaizen), de trabalho just-in-time (kanban) e o papel que é aqui conferido aos operadores no sentido da melhoria da eficácia produtiva tornam, segundo Coutrot (ibidem), o modelo de produção magra japonesa bastante frágil.

A especialização flexível à italiana assenta no conceito de "distrito industrial", tratando-se de um conjunto de Pequenas e Médias Empresas que se localizam numa determinada região ou bacia de emprego, com redes fundadas 
nas solidariedades locais e profissionais. A força destas redes de empresas reside não nos seus avanços tecnológicos ou na sua capacidade de inovação, mas sim na sua capacidade de resposta a procuras específicas de sectores relativamente tradicionais (por exemplo, da siderurgia ou da metalurgia), de forma rápida e com um custo baixo.

Pelo seu lado, a produção alemã diversificada e de qualidade assenta na relação entre os sistemas educativo e produtivo, com um ensino profissional de qualidade em cuja definição participam ativamente os empresários e que fornece uma mão-de-obra altamente qualificada para o mercado de trabalho.

Importa, pois, contextualizar a emergência de novos modelos produtivos - associada a uma necessidade de participação ativa e de controlo - no âmbito de uma crise do modelo da operação e do modelo da cooperação. A unidade de ação e de medida característica do modelo clássico de organização estruturava a atividade em operações (humanas e mecânicas): é ao pretender alcançar a eficácia que, em concreto, o discurso gestionário se focaliza na produtividade do trabalho, mas tal enfoque não significa o obliterar da produtividade das operações técnicas ou o abandono de questões como a flexibilidade e a gestão racional dos fluxos. Contudo, as técnicas de Gestão de Recursos Humanos (GRH) e de desenvolvimento organizacional (DO) características da década de 1990 contribuíram para a emergência do que Coutrot (ibid.) designa como "regime de mobilização neoliberal": setores-chave de acumulação de capitais (indústrias químicas e farmacêuticas, automóvel, eletrónica, serviços prestados às empresas, serviços de grande distribuição, etc.) sofreram alterações nos seus critérios de performance, tornando indispensáveis para a gestão não apenas a redução de custos e as economias de escala, mas também a elevação da qualidade e o aumento da variedade dos produtos e dos serviços, a capacidade de reação às necessidades dos clientes, de adaptabilidade e de inovação de produtos e de procedimentos ${ }^{5}$.

Trata-se - e isso é muito importante - de um problema de critério de valor e de medição do desempenho:

(1) Os mercados financeiros fornecem a todos os atores sociais envolvidos na empresa - acionistas, gestores e assalariados - uma medida imediatamente acessível da norma de eficácia económica.

5 O Fordismo e suas variantes predominaram por quase todo o século XX nas sociedades capitalistas industriais. Desde que este sistema de organização da produção entrou em crise a meio de 1970, têm existido varias tentativas de transcender as dificuldades associadas ao mesmo, incluindo a automatização, internacionalização e reorganização da produção. Por exemplo, os fabricantes de veículos suecos desenvolveram algumas das mais recentes e notáveis experiências para modificar a organização de produção fordista, um processo que foi iniciado pela Volvo na sua fábrica de carros Kalmar, em 1974, e que culminou num sistema de "montagem holística" altamente automatizado na fábrica de carros Uddevalla, em 1989. Uma avaliação de experiências anteriores da Volvo mostrou que "o trabalho em si mesmo ainda se divide em diferentes estações de trabalho, mais ou menos na maneira tradicional" e estudos de tempos e movimentos tayloristas ainda eram usados para estabelecer o tempo permitido para a finalização de uma tarefa (Edgell, 2012). 
(2) Reconhecidas as dificuldades de elaboração de indicadores objetivos de produtividade que permitam decompor e medir a eficácia das organizações modernas (e considerando que também não serão os indicadores de produtividade física a possibilitar um tal desidrato), as empresas tendem a considerar cada vez mais critérios de ordem financeira para avaliar a sua performance produtiva. (3) Para Coutrot (ibid.), estes critérios avaliativos traduzem-se em novas formas de mobilização do coletivo de trabalho: a representação diagramática do regime de mobilização da força de trabalho considera o sistema técnico, organizacional e social inseridos num mercado e enquadrados por regras e por instituições estáticas, organizando as condições de transformação da força de trabalho em trabalho efetivo, numa lógica que sublinha a heterogeneidade entre a lógica económica e a lógica social.

\section{Uma proposta de "sistema" baseado numa avaliação holística}

É neste contexto de mutações nas dinâmicas do trabalho que se disseminam os sistemas de avaliação dos desempenhos aplicados à gestão do trabalho e dos recursos humanos nas empresas, em particular, a partir da década de 1980, podendo situar-se o seu apogeu na década de 1990 e seguintes (Almeida, 2012a, 2012b).

Atualmente, as organizações reconhecem que "pessoas/ trabalhadores/ colaboradores" são uma fonte de vantagem competitiva, pelo que os departamentos/direções de recursos humanos (DRH) têm sofrido mutações no seu enquadramento organizacional (Dessler, 2012; Tyson, 2015): (1) de um papel meramente "administrativo" tornaram-se "sócios estratégicos", responsáveis por contribuir para a prossecução dos objetivos do negócio das organizações, em geral, e das empresas, em particular; (2) esta evolução exige novas formas de definição e avaliação do sucesso dos trabalhadores; (3) esta alteração é acompanhada por uma dificuldade das DRH em acompanhar os atores sindicais e vice-versa.

Todavia, uma organização precisa constantemente de fazer um balanço da sua força de trabalho e de avaliar o seu desempenho em postos de trabalho existentes, isto por três razões essenciais: (1) para melhorar o desempenho organizacional através da melhoria do desempenho das contribuições individuais; (2) para identificar o potencial, ou seja, reconhecer o talento existente e usá-lo para preenchimento de vagas na organização ou para a transferência de indivíduos para postos de trabalho onde pode ser feita uma melhor utilização das suas habilidades ou desenvolvimento das suas competências; e (3) para fornecer um método justo de vincular o pagamento à performance, especialmente onde não há um critério numérico.

Basicamente, um regime de avaliação é, muitas vezes, uma formalização do que é feito de uma forma mais informal. Contudo, este deve, então, e em 
nosso entender, conter alguns aspetos de avaliação multicritério que, acreditamos, introduzirá um maior sentimento de justiça e de equidade. Nesse sentido, e acompanhando Gadrey (1999), propomos uma adoção adaptada da grelha do quadro seguinte (quadro 4) que: (1) dada a multiplicidade de situações que contempla e as possibilidades que considera, poderá servir para medir os produtos diretos (performances, fluxos de problemas, operações de serviço); e (2), em simultâneo, medir os resultados ou impactos a longo prazo (isto é, estado ulterior das realidades tratadas para além das operações efetuadas sobre estas).

\section{Quadro 4}

\section{Avaliação dos desempenhos multicritério: proposta de boas práticas}

\begin{tabular}{l|l|l|l|l|l|l|}
\hline $\begin{array}{l}\text { Avaliação } \\
\text { dos desempe- } \\
\text { nhos }\end{array}$ & $\begin{array}{l}\text { Critérios } \\
\text { Técnicos ou } \\
\text { Industriais }\end{array}$ & $\begin{array}{l}\text { Critérios de } \\
\text { Mercado } \\
\text { ou } \\
\text { Financeiros }\end{array}$ & $\begin{array}{l}\text { Critérios } \\
\text { Relacionais }\end{array}$ & $\begin{array}{l}\text { Critérios } \\
\text { Cívicos e } \\
\text { Ecológicos }\end{array}$ & $\begin{array}{l}\text { Critérios de } \\
\text { Criatividade } \\
\text { ou de } \\
\text { Inovação }\end{array}$ & $\begin{array}{l}\text { Critérios de } \\
\text { Imagem ou } \\
\text { Reputação }\end{array}$ \\
\hline $\begin{array}{l}\text { Produtos e } \\
\text { Resultados } \\
\text { Diretos da } \\
\text { Atividade }\end{array}$ & & & & & \\
\hline $\begin{array}{l}\text { Performances } \\
\text { correspon- } \\
\text { dentes } \\
\text { (output) }\end{array}$ & & & & & \\
\hline $\begin{array}{l}\text { Produtos e } \\
\text { Resultados } \\
\text { Indiretos }\end{array}$ & & & & & \\
& & & & & \\
\hline $\begin{array}{l}\text { Performances } \\
\text { correspon- } \\
\text { dentes } \\
\text { (outcome) }\end{array}$ & & & & & \\
\end{tabular}

\section{Nota conclusiva}

A proposta que detalhámos ao longo do presente artigo já tem vindo a começar a ser testada com bons resultados na avaliação dos desempenhos (médicos, jurídicos, comerciais, diretivos, letivos, etc.) e permite distinguir entre output e outcome. Possibilita, ainda, - e isso é muito importante - fazer uma ligação mais direta entre a avaliação dos desempenhos e o valor dos salários, mas essa componente variável não deve, em nosso entender, ultrapassar os $20 \%$, no máximo, quando aplicada a organizações do trabalho, em geral, e 
a organizações complexas, em particular, sob pena de se criar sentimentos de falta de equidade salarial e de desmotivação contrários a uma organização de elevada performance, um desejo claramente assumido no contexto e envolvente das organizações de trabalho no século XXI.

\section{Referências bibliográficas}

ALMEIDA, Paulo Pereira de (2005), Trabalho, Serviço e Serviços: Contributos para a sociologia do trabalho, Porto, Edições Afrontamento.

ALMEIDA, Paulo Pereira de (2009), The Service Enterprise: A key concept for the Sociology of Work, New York, VDM Verlag Publishing.

ALMEIDA, Paulo Pereira de (2011), "Trabalho moderno e serviço: uma discussão de tipologias e definições”, Sociologia, Problemas e Práticas, 67, pp. 23-42.

ALMEIDA, Paulo Pereira de (2012a), Variações Sobre o Trabalho Moderno, Lisboa, Editora Mundos Sociais.

ALMEIDA, Paulo Pereira de (2012b), Gerir com Competência: manual para a empresa do século XXI, Lisboa e São Paulo, Bnomics.

COUTROT, Thomas (1998), L'Entreprise Néo-libérale, Nouvelle Utopie Capitaliste? Enquête sur les Modes d'Organisation du Travail, Paris, Éditions de La Découverte.

DESSLER, Gary (2012), Human Resource Management, New York, Prentice Hall.

EDGELL, Stephen (2012), The Sociology of Work: Continuity and change in paid and unpaid work, London, Sage.

GADREY, Jean (1999), "Flexibilité et professionalisation du travail dans les services: des stratégies et des modèles distincts”, Économies et Sociétés, 1, pp. 117-141.

GADREY, Jean, ZARIFIAN, Philippe (2002), L'Émergence d'un Modèle du Service: Enjeux et réalités, Paris, Éditions Liaisons.

GIDDENS, Anthony (2011), Sociologia, Lisboa, Fundação Calouste Gulbenkian.

INSTITUTO NACIONAL DE ESTATÍSTICA (1990-2010), Inquérito Nacional ao Emprego, Lisboa.

IRIBARNE, Alain d' (1993), La Competitivité: Défit social, enjeu éducatif, Paris, Centre National de Recherche Scientifique.

MACDONALD, Keith (1995), The Sociology of the Professions, London, Sage.

OCDE (2011), Employment Statistics, Paris.

ORGANIZAÇÃO INTERNACIONAL DO TRABALHO (2001), “Definition of decent work" [Online] disponível em: http://www.ilo.org/global/topics/decent-work/lang--en/index.htm [consultado em 13-03-2017].

SENNETT, Richard (2009), The Craftsman, London, Penguin.

TYSON, Shaun (2015), Essentials of Human Resource Management, New York, Routledge.

ZARIFIAN, Philippe (1999), Objectif Compétence: Pour une nouvelle logique, Paris, Éditions Liaisons.

ZARIFIAN, Philippe (2001), Le Modèle de la Compétence: Trajectoire historique, enjeux actuels et propositions, Paris, Éditions Liaisons.

ZARIFIAN, Philippe (2009), Le Travail et la Compétence: Entre puissance et contrôle, Paris, Presses Universitaires de France. 
Benedito, Fernanda Costa dos Santos - Quando Tudo Se Desmorona: Um Contributo Literário à Inter-historicidade. Configurações, vol. 19, 2017, pp. 19-31

\title{
Quando Tudo Se Desmorona: Um Contributo Literário à Inter-historicidade
}

FERNANDA COSTA DOS SANTOS BENEDITO*

Faculdade de Letras da Universidade Agostinho Neto

\begin{abstract}
Resumo
O presente artigo aborda criticamente a obra Quando Tudo Se Desmorona (2008 [1958]), de Chinua Achebe, à luz da reflexão teórico-crítica desenvolvida no quadro dos estudos pós-coloniais e no âmbito da teoria do romance polifónico e carnavalesco de Mikhail Bakhtin, nomeadamente através dos conceitos de contradiscurso, (inter)historicidade, transculturalidade e carnavalização, respetivamente. Pretendemos evidenciar o papel da memória na produção da narrativa das "vozes" silenciadas pela História do recontro colonial e a contribuição dessa narrativa para a (re)afirmação da "autonomia" e do posicionamento da cultura igbo, no quadro da cultura cosmopolita.
\end{abstract}

Palavras-chave: inter-historicidade, contradiscurso, transculturalidade; memória social.

\begin{abstract}
Things Fall Apart: A Literary Contribution for Inter-bistoricity

This paper critically analyses the novel Things Fall Apart (2008 [1958]), by Chinua Achebe, in light of a post-colonial approach and the theory of the carnivalistic and polyphonic novel of Mikhail Bakhtin, namely through the concepts of counter-discourse, (inter-)historicity, interculturality and carnivalisation, respectively. It is intended to highlight the role of the memory in the production of the narration of "voices" silenced by the history of colonial clash and the contribution of that narration for the (re)affirmation of the "autonomy" of the Igbo culture and its position inside cosmopolitan culture.
\end{abstract}

Keywords: inter-historicity, counter-discourse, transculturality, social memory.

*Centro de Estudos Humanísticos da Universidade do Minho, CEHUM. E-mail: fernandasantos04@ yahoo.com.br 


\section{Résumé \\ Le Monde s'effondre : une contribution littéraire à l'inter-historicité}

Cet article analyse de manière critique l'œuvre Le Monde s'effondre (2008 [1958]), de Chinua Achebe, en ayant pour base la réflexion théorico-critique des études postcoloniales et la théorie du roman polyphonique et carnavalesque de Mikhail Bakhtin à travers les concepts de contre-discours, d'(inter-)historicité, de transculturalité et de carnavalisation. L'objectif est de mettre en évidence le rôle de la mémoire dans la production du récit des "voix » mises sous silence par l'Histoire de la confrontation coloniale et la contribution de ce récit à la (ré)affirmation de l' " autonomie » de la culture igbo et de sa place dans la culture cosmopolite.

Mots-clés : inter-historicité, contre-discours, transculturalité, mémoire sociale.

\section{Introdução}

A análise da narrativa de Chinua Achebe que nos propomos fazer não deve, em nosso entender, ser efetuada à margem da história associada ao processo colonial e às suas inerentes tensões e consequências. O simples facto de essa narrativa ser apresentada numa língua originária do continente europeu constitui, desde logo, um indicador da indissociabilidade do labor literário de Achebe à colonização da Nigéria de onde o autor é originário.

Essa constatação impele-nos a uma referência ao processo de "centralização" da Nigéria, sendo o termo centralização aqui usado, metaforicamente, para referir as transformações operadas no seio das sociedades africanas, em geral, e da igbo, em particular, em decorrência das políticas ditadas pelo poder colonial. Essas políticas marcaram sobremaneira a produção e a divulgação do discurso histórico, ficando o mesmo visivelmente acoplado à visão ocidentalizada sobre espaços onde o colonialismo aportou. Assim, a noção de "a-historicidade", aliada à ideia de inferioridade civilizacional e cultural dos povos colonizados, converteu-se numa das marcas indeléveis do processo de "centralização".

É, precisamente, no quadro dessa hierarquia, gerada pela colonização, que conduziremos a leitura da obra Quando Tudo Se Desmorona (2008 [1958]), de Achebe. Para tal, partimos de uma perspetiva teórica subjacente à crítica pós-colonial e ao quadro do romance carnavalesco e polifónico de Mikhail Bakhtin. Pretendemos evidenciar a riqueza histórico-cultural patente no nosso corpus e o papel da memória como fonte do conhecimento histórico e a sua relevância para a conceção de um discurso alternativo aos cânones ocidentais por via da literatura. Constitui também nossa intenção ressaltar os pontos de confluência entre os substratos teóricos que sustentam a nossa análise. 


\section{A dimensão ideológica do discurso histórico no contexto (pós) colonial}

Começamos a nossa abordagem pelo campo da produção do discurso histórico no quadro da dicotomia centro-periferia resultante da cartografia colonial, lembrando, para o efeito, Edward Said (1983 [1975]), que sublinha o facto de os textos serem institucionalizados pelas culturas reinantes como resultado de alguns custos humanos. A título de exemplo, assinalamos os textos escritos a partir de uma perspetiva colonial que, ao serviço das culturas dominantes, revela(r)am uma "miopia seletiva" no exercício de registo e divulgação das realizações das culturas dominadas/colonizadas, havendo, por este facto, a necessidade de se alterar esse quadro seletivo.

No campo da história, por exemplo, a inclusão das perspetivas específicas dos emudecidos implica a realização de um complexo esforço para a erradicação da monoglossia patente no discurso histórico sobre o colonialismo produzido pelo ocidente. Esse esforço passa pela crítica epistemológica dos termos e contextos da produção do conhecimento histórico, pela desnaturalização dos significados e referências cognitivas, pela inclusão dialógica dos impensados e das experiências dos colonialismos, como sublinham Catarina Gomes e Paula Meneses (2011). Para Gomes e Meneses (idem, ibidem), o facto de as histórias coloniais revelarem uma incompletude cultural transforma-as em locais de excelência para a prática de um exercício de hermenêutica diatópica dos factos históricos, do qual resultará, necessariamente, um diálogo entre as culturas centrais e periféricas. No campo da história, este exercício de interculturalidade converte-se, no dizer dessas autoras, num exercício de inter-historicidade.

Analisando a produção de textos, em geral, importa reconhecer que cada texto constitui uma ocasião de afirmação de vozes e está localizado num contexto específico que, por seu turno, é parte integrante de um contexto mundial, ou cosmopolita, como refere Said (1983 [1975]: 39). Esses fatores obrigam a que a análise de cada texto seja concebida à luz das suas circunstâncias específicas. A partir dessa necessária conexão, o texto é tido como um evento detentor de particularismos históricos. Isto significa que, no quadro de um ambiente global, cada texto detém uma situação específica, devendo a crítica literária prestar atenção ao ambiente sociocultural a partir do qual o mesmo é lido e/ ou concebido (idem: 35). Assim, para os escritores e críticos pós-coloniais, essa indispensável atenção constitui um fator crucial para a localização, evocação e afirmação do seu espaço geográfico, assim como para a apresentação da sua liminaridade, sendo estas marcas fundamentais da sua presença, intervenção e permanência no mundo (Ashcroft e Ahluwalia, 2001: 21-22).

A leitura crítica dos textos ao abrigo do binário "filiação e afiliação", como já referimos, ilumina a possibilidade de olhares críticos diferenciados. Uma vez que o conceito de filiação está ligado à divisão da sociedade entre 
centro e periferia e vinculado a processos de identificação cultural, Said (1983 [1975]: 35) promove o conceito de afiliação como um princípio orientador da crítica humanista visando estimular abordagens plurais sobre o texto literário e libertar o crítico de análises assentes numa estreita relação de "filiação" dos textos não ocidentais aos seus congéneres ocidentais, dominantes. Para Said (idem, ibidem), a afiliação permite ver o texto como um fenómeno do mundo, localizado, de modo transversal, numa teia de desconexões não literárias, não canónicas e não tradicionais, libertando, assim, a crítica da visão ancorada no cânone europeu, factos que, na nossa perspetiva, permitem a audição plena das vozes localizadas em contextos não ocidentais.

Porém, a transposição das vozes locais para o universo literário decorre de um exercício de revisitação de factos histórico-sociais. Assim, a memória desempenha um papel preponderante ao servir como ferramenta para a recuperação, transmissão e preservação de legados, abrindo-se, por via desse tríplice exercício, a possibilidade de (re)construção de textos alternativos, ancorados numa perspetiva de inclusão dialógica das vozes das culturas ditas marginais. Ou seja, esse exercício de revisitação permite a eclosão de contradiscursos promotores da ideia de transculturalidade, sendo esta uma característica marcante das atuais identidades culturais, fundamentalmente as não-ocidentais. Entendemos, por este facto, ser relevante efetuar uma breve abordagem à questão da identidade e ao papel da memória social na edificação das identidades culturais.

\section{A memória social e a construção da identidade cultural}

Referindo-nos, agora, à questão da identidade cultural, importa frisar que a mesma constitui um domínio cuja delimitação a um único campo do saber científico se afigura difícil pelo facto de estar intimamente ligada ao estudo da memória social, um domínio cujas abordagens percorrem, por seu turno, distintas áreas científicas.

De um modo geral, a identidade cultural coletiva pode ser definida como a via pela qual uma comunidade se demarca de outras, partindo do delineamento de caracteres próprios, que vão desde as línguas às manifestações culturais, passando pela história dessa comunidade. Os núcleos gestacionais da identidade coletiva localizam-se num passado comum e a mesma vai sendo consolidada ao longo de várias fases da construção de uma determinada sociedade. A identidade cultural coletiva aliada à nação implica um sentimento de pertença a uma nação e pressupõe a partilha de referências a um passado comum, a uma memória e à crença de que o seu coletivo detém características próprias, ou seja, uma identidade, podendo esta ser aferida em distintos níveis 
(Sobral: 2006, 2) ${ }^{1}$, como, por exemplo, a um nível nacional, estando ancorada a uma memória social cuja definição, por seu turno, emana de uma conceção sociológica da memória, proposta por Maurice Halbwachs². Halbwachs (1992 [1925]: 14) considera a memória como um facto social porquanto a edificação da mesma pressupõe a existência de uma relação de partilha cultural no seio de um determinado grupo social. A memória social, opina Halbwachs (idem: 36), constitui uma reconstrução e uma representação do passado elaborada no presente, tendo como base depoimentos de testemunhas ou de partícipes de factos que ocupam lugar na memória de uma nação.

Halbwachs (idem, ibidem) sublinha que qualquer lembrança, ainda que pessoal, se encontra relacionada com um conjunto de noções ligadas à vida material e moral das sociedades. Esta perspetiva enfatiza a dimensão social da memória, sem, contudo, esquecer a sua vertente individual (Halbwachs, 1992 [1925]: 15). Embora existam outras conceções da memória ${ }^{3}$, todas elas acabam por ligá-la a um espaço de partilha que nos conduz a um sentimento de pertença a um grupo social (Sobral, 2006: 3). Como sublinha Halbwachs (1992 [1925]: 37), a memória individual tem necessidade de apelar a lembranças do nosso grupo social de pertença, reportando-se a pontos de referência fixados pela sociedade.

Elsa Peralta (2007: 6), alinhando no diapasão de Halbwachs, lembra que é na sociedade que os indivíduos adquirem as suas memórias, ficando, assim, as memórias individuais sujeitas aos padrões coletivos. Isto ocorre porque, como diz Peralta (idem, ibidem), em última análise, o que recordamos, enquanto indivíduos, é sempre condicionado pelo facto de pertencermos a um grupo. No entanto, convém ressaltar que a sujeição da memória a determinismos sociais não implica negligenciar as tensões dialéticas entre a memória individual e a construção social do passado, daí que o indivíduo não possa ser considerado uma espécie de "autómato" passivamente obediente à vontade coletiva (idem, ibid.).

Em suma, pertencemos a comunidades mnemónicas, podendo estas ser de âmbito micro e macrossocial (família e nação, respetivamente). Enquanto seres sociais, possuímos uma identidade social que se ramifica em distintos campos (classe, género, ocupacional, etc.), sendo a identidade nacional uma

1 Usando o exemplo europeu, Sobral considera que podemos falar de uma identidade supranacional, ligada à União Europeia (U.E.), e de uma identidade nacional. Sobral (Sobral: 2006, 3) sublinha que o sentimento de pertença à Europa se manifesta, sobretudo, em termos institucionais, ligados ao presente, enquanto a ligação à nação ocorre por via da memória social, com enfoque ao passado, à história e a dimensões culturais ou a uma identidade coletiva, que conduz a Nós.

2 Pelo facto de recordar constituir um ato eminentemente individual, durante muito tempo, a base social da memória foi negligenciada. Só recentemente as ciências sociais passaram a dedicar uma maior atenção a esta matéria, sendo de atribuir a Halbwachs a inauguração da abordagem sobre a memória como fenómeno eminentemente coletivo, colocando-a, assim, na agenda das ciências sociais (Peralta, 2007: 5).

3 Como, por exemplo, a psicológica, a paleontológica e a neurocientista. Vide Sobral (2006: 3-4) para uma leitura detalhada. 
delas, que se resume no Nós e na constatação da nossa diferença relativamente a outros, tal como afirma José Manuel Sobral (2006: 10). O autor acentua também as implicações que a globalização aporta ao conceito de identidade, atendendo à troca de valores culturais e à profusão de diásporas (idem: 1) e, por consequência, a e/imigração de traços identitários.

Os argumentos epigrafados relativos à memória, nomeadamente o seu papel na formação da identidade coletiva, a sua relação com um espaço de pertença e de partilha de valores, assim como a um passado histórico, permitem-nos falar em identidades coletivas transculturais. Esta aceção do conceito pode ser entendida como aquela identidade resultante de ligações contínuas de contaminação que distintas culturas tece $(\mathrm{ra}) \mathrm{m}$ em consequência de vários fenómenos sociais, como, por exemplo, a expansão europeia e o colonialismo, que viriam a ditar os atuais mosaicos geográficos e socioculturais africanos, por exemplo, fortemente marcadas por uma transculturalidade.

$\mathrm{O}$ conceito de transculturalidade surge face à inadequação dos seus congéneres multi e interculturalidade para a descrição da fisionomia cultural das sociedades atuais pelo facto de ambos encararem as culturas como "ilhas", como territórios fisicamente demarcados por rígidas fronteiras naturais (Welsch, 1999: 194-195). Ao partir do pressuposto da delimitação territorial das culturas, os conceitos de multi e interculturalidade, embora dotados de uma conotação mais positiva relativamente ao conceito tradicional de cultura ${ }^{4}$ por admitirem a interação entre culturas, revelaram-se inadequados à descrição da atual situação sociocultural. Decorre dessa afirmação o facto de quer o conceito de multi, quer o de interculturalidade ignorarem o processo de transculturação ${ }^{5}$ que ocorre nas sociedades modernas dada a multitude de culturas que as mesmas congregam, como já referimos. Logo, o conceito de transculturalidade $^{6}$ surge, segundo Welsch (idem, ibidem), para articular a nova realidade cultural resultante da colonização e da globalização, que engloba vários estilos de vida e culturas que se interpenetram ou emergem uma da outra.

4 Por exemplo, o conceito desenvolvido no século XVIII, por Johan Gottfried, caracterizava-se por três elementos: a harmonia social, a consolidação étnica e a delimitação espacial entre as culturas (Welsch, 1999: 194). Este conceito realça oposições binárias como Eu/outro e nativo/estrangeiro, perspetivando, de um modo genérico, a exclusão do elemento situado em segundo lugar na categoria binária.

5 A transculturação refere-se à influência cultural recíproca observada nos modos de representação e práticas culturais que ocorrem em "zonas de contacto", que são espaços sociais onde distintas culturas se encontram, colidem, geralmente por via de relações assimétricas de domínio e subordinação, tal como diz Mary Louise Pratt (cit. in Ashcroft, Griffiths e Tiffin, 2004: 233). O termo foi proposto em substituição dos termos aculturação e desculturação, por estes descreverem, de forma redutora, as trocas culturais, enfatizando o sentido centro- periferia dessas trocas e ignorando, portanto, a possibilidade da reciprocidade das influências, ainda que desequilibrada.

6 A transculturalidade repercute-se a nível macro e micro. O primeiro nível está associado à complexidade e à extrema interconexão observável entre as culturas e constitui uma característica fundamental das sociedades atuais, decorrente dos processos migratórios e das facilidades proporcionadas pelos sistemas mundiais de comunicação. O nível micro reflete-se no indivíduo, uma vez que a realidade associada ao nível macro altera também a formação cultural do indivíduo, que se torna, genericamente, híbrido (Welsch, 1999: 196-197). 
Como afirma Said (cit. in Huggan, 2001: 9), deve ser colocado o foco no hibridismo da cultura (...) patente nas novas configurações do mapa cultural. Esta perspetiva, argumenta Graham Huggan (2001: 9), proporciona solidariedades transnacionais na era da fragmentação cultural e da dispersão de pessoas, bens e ideias.

Embora a transculturalidade não seja uma realidade recente, uma vez que ela começa, na verdade, com a conquista dos novos mundos, o conceito vem dar resposta à necessidade de se efetuar uma leitura adequada do(s) contexto(s) sociocultural(is) dos nossos dias e das suas ligações ao passado histórico. Esta constatação sanciona, em nossa opinião, a relação entre os conceitos de transculturalidade e inter-historicidade, estando estes conexos a uma memória social.

Em síntese, entendemos a identidade coletiva transcultural como aquela que se funda no reconhecimento das influências mútuas, que se realiza(ra)m entre as culturas, resultando numa interpenetração cultural, ainda que, por vezes, desproporcional e, por isto, geradora de alguma tensão, também ela objeto de registo por parte da memória. No quadro da dinâmica cultural acima descrita, emergem várias dissonâncias, cada uma delas evidenciando ações conducentes à promulgação de discursos que chamam a atenção para formas explícitas ou dissimuladas de discriminação, constituindo, assim, alertas sobre a eclosão de novos modelos de colonização.

É, precisamente, dentro do quadro de um mútuo reconhecimento entre as distintas culturas que o pensamento crítico de Bakhtin, nomeadamente através dos conceitos de carnavalização e de dialogismo, assim como da sua conceção sociológica da palavra "voz" , tece diálogos com as questões relativas à memória social e ao conceito de transculturalidade. Em geral, esses conceitos bakhtinianos, por um lado, repudiam o silenciamento; por outro, enaltecem a importância da capacidade de conhecimento do Outro através da observância da sua vez e do respeito pela sua "voz". O ponto de convergência desses conceitos situa-se na ideia do contacto livre e familiar entre pessoas e o "diálogo de vozes". Como refere Bakhtin (1984: 123), o contacto livre entre pessoas permite a interação de diferentes culturas e distintos estratos sociais que se encontram na arena do carnaval, sendo esta o símbolo da performance comum"s. Para Bakhtin (1998: 263), essa amálgama de atores concorre para a existência de uma diversidade de discursos, ou seja, um dialogismo ou heteroglossia, que se converte em polifonia, quando é transposto para o universo literário. A configuração da heteroglossia fora do universo literário, por exemplo, ao nível da

7 Bakhtin usa a palavra "voz" de modo especial, relacionando-a não apenas com aspetos linguísticos, mas também com questões de natureza social. Para Bakhtin (1998: 332), o vocábulo "voz” está também conexo à ideologia, poder, grupos sociais e à necessidade da sua representação.

8 Além do contacto livre e familiar, outro aspeto conexo ao conceito bakhtiniano de carnaval é o seu principal ato, a coroação do rei ou da rainha do carnaval, como resultado da destronização dos seus predecessores, funcionando como uma metáfora da renovação. Vide Bakhtin (1984: 123-124). 
produção e divulgação do conhecimento histórico implica, necessariamente, leituras críticas plurais, despojadas de noções filiadas numa matriz reducionista e centralizadora do pensamento crítico, isto é, leituras minuciosas das componentes dos contradiscursos presentes nos textos que reagem à dimensão colonizadora dos discursos nos mais distintos campos, sendo essa a premissa que preside a análise da obra de Achebe que seguidamente efetuamos.

\section{Anarrativa achebiana no contexto da inter-historicidade pós-colonial}

Consagramos os próximos parágrafos à análise crítica de Quando Tudo Se Desmorona, de Chinua Achebe (2008 [1958]), à luz da abordagem efetuada. $\quad \mathrm{O}$ romance de Achebe tem como temas estruturais a realidade resultante do contacto entre as civilizações igbo e inglesa. Ao longo da obra, a história da comunidade igbo é recuperada através da trajetória de Okonkwo, a personagem principal da trama, que luta para preservar a coesão dos igbo, visando mantê-los isentos da "contaminação" e da subjugação britânica. Assim, comparecem também no discurso narrativo os conquistadores, alheios ao ambiente sociocultural local. A temática convocada para a obra, elaborada por via de uma narrativa ancorada numa hibridação discursiva, própria da literatura carnavalizada e pós-colonial, descreve as realidades pré e pós-colonial específicas da comunidade igbo. Assim, as "vozes" e o tempo são inter-relacionados de modo a produzir um quadro alegórico do "encontro" colonial.

O capítulo inaugural anuncia o ambiente carnavalesco do romance através da coroação de Okonkwo, aos dezoito anos, antecedida da destronização de Amalinze, como resultado da sua derrota após sete anos de invencibilidade quebrados por Okonkwo. Assistia-se, assim, a uma renovação. Como refere Bakhtin (1984: 125), o ritual da entronização e destronização expressa a inevitabilidade da mudança e, simultaneamente, o poder criativo da renovação, assim como a contingência de todas as estruturas, autoridades e hierarquias. No caso de Quando Tudo Se Desmorona, a ascensão de Okonkwo representa a renovação da comunidade igbo no período anterior à presença inglesa. No entanto, outras categorias associadas à lógica do carnaval e ao romance carnavalesco, por exemplo, o contacto livre e familiar entre atores pertencentes a diferentes categorias sociais (mesalliances) $)^{9}$, são apresentadas à medida que o enredo se desenvolve. Nessa conformidade, é possível observar a união entre jovens e idosos, entre a alta e a baixa sociedade conectadas em típicas mesalliances (juntos, os polos opostos trabalhavam para a manutenção das normas inerentes à civilização igbo e à preservação da sua identidade). Convém referir que as alianças entre opostos são reforçadas pelo facto de, em muitas ocasiões, 
as mesmas ocorrerem na "ilo", a praça central de Umuofia, a capital dos igbo. Em termos comparativos, a "ilo" corresponde à praça carnavalesca, o ponto de encontro de todas as classes e símbolo da performance comum, ou seja, a arena do carnaval, a carnival square ${ }^{10}$ de que nos fala Bakhtin. Como resultado desse amalgamento, o sagrado e o profano coabitam, confirmando, assim, a união dos opostos em Umuofia.

$\mathrm{Na}$ sua qualidade de "rei" e de entidade unificadora de Umuofia, as ações de Okonkwo eram legitimadas pelo direito costumeiro e pelas crenças que regulavam a vida da comunidade igbo. Tal como o direito positivo, o direito costumeiro contém proibições e punições, tendo estas punições conduzido Okonkwo à primeira fase da sua destronização e consequente exílio em Mbata após ter assassinado um rapaz. Essa punição é acompanhada por uma profanação simbólica, marcada pela destruição dos seus pertences e pela queima da sua casa como meio de purificação de Umuofia, ao abrigo das leis locais. Tais atos remetem, uma vez mais, para a nossa leitura ao pensamento de Bakhtin (1984), que alude à presença do fogo como elemento associado ao carnaval, fundamentalmente no que diz respeito à sua natureza ambivalente, ou seja, o seu poder de destruição e a possibilidade de renovação engendrada por esse mesmo poder destrutivo. Com o exílio de Okonkwo, consuma-se a presença europeia em Umuofia. O desembarque de missionários ingleses em Umuofia forçou a abertura de espaços no mosaico dos hábitos locais, ocorrendo, assim, as primeiras etapas da contaminação cultural de Umuofia e da construção de uma realidade transcultural, silenciadora da identidade do povo igbo e, por esse facto, desequilibrada. De algum modo, essa realidade constituía, na verdade, os alicerces sobre os quais se veio a erguer o processo de globalização ${ }^{11}$ dos espaços de aportamento das "missões civilizadoras". Como sublinham Ashcroft, Griffiths e Tiffin (2004: 110),

A globalização é o processo pelo qual indivíduos e comunidades locais são afectados por forças económicas e culturais que operam a nível mundial. De facto, é o processo de transformação do mundo numa aldeia global (...). Ela reflete uma mudança na organização das relações sociais, uma vez os indivíduos e as comunidades têm acesso ao conhecimento e às culturas globalmente disseminadas.

10 A praça pública é o símbolo da performance comum. A arena central só pode ser a praça pública uma vez que a ideia central subjacente ao carnaval é a de que o mesmo é universal e todos dele devem participar por via de contactos "familiares" (Bakhtin, 1984: 128).

11 Embora o termo tivesse ascensão meteórica a partir de meados da década de 80 do século passado, o processo, como tal, começa com a "descoberta dos novos mundos", ou seja, no século XV, com a expansão europeia. O século XV constituiu o ponto de partida, uma vez que o mundo começa, nessa altura, a ser afetado por forças económicas e culturais que operavam à escala planetária, mais especificamente as forças europeias. Na verdade, a diferença, hoje, reside na presença de novos atores (E.U.A., China, por exemplo) e de outros fatores como as diásporas, as TIC e os media, que vieram facilitar ou acelerar o processo. 
A citação anterior dá-nos a sensação de estar perante um processo inócuo. Porém, recordam Ashcroft, Griffiths e Tiffin (idem: ibidem), a globalização envolve muitos fatores aos quais são inerentes distintas questões, das quais salientamos aquelas ligadas a aspetos antropológicos e à configuração dos espaços territoriais, que, por sua vez, trazem à tona o conceito de imperialismo ecológico porquanto este descreve o modo como as sociedades colonizadas foram fisicamente transformadas pela experiência da ocupação colonial.

Assim, através da arte literária, Achebe descreve, de forma dramática, a fenda que se gerou no (sub)solo que sustentava os pilares da comunidade igbo nos primeiros momentos da sua ocidentalização, ou seja, da sua “centralização". Para tal, o autor rebusca capítulos da história silenciados pela historiografia colonial e coloca ao dispor dos seus leitores uma versão "desmascarada" desses capítulos narrada pela voz do "invadido", assumindo e enumerando também as debilidades dos igbo, quando revela, por exemplo, a "permissão" dada aos ingleses para procederem à ocupação da "igbolândia". Podemos observar no romance que há uma culpa partilhada relativamente à situação sociocultural desenvolvida em Umuofia após a chegada dos ingleses, pois, como afirma Obierika (in Achebe, 2008 (1958): 152-153),

"Os nossos homens e filhos juntaram-se às fileiras dos estranhos. Juntaram-se a esta religião e ajudam a sustentar este governo (...). O homem branco é muito esperto. Chegou calma e pacificamente com a sua religião. Divertimo-nos com os seus disparates e permitimos que ficasse. Agora conquistou os nossos irmãos e o nosso clã já não pode agir como um. Apontou uma faca ao que nos mantinha unidos e nós desmoronámos".

A transcrição anterior reproduz o lamento pelo resultado do confronto entre as culturas igbo e inglesa, nomeadamente, a quebra dos alicerces que sustentavam a comunidade igbo e a construção forçada de um novo espaço transcultural, "partilhado" por invasores e invadidos, durante os sete anos de exílio de Okonkwo em Mbata e nos anos subsequentes. O regresso de Okonkwo à Umuofia representa a segunda etapa da sua destronização. A sua ausência resultou na influência marcante da presença dos missionários que, como já afirmámos, operaram visíveis mudanças nos costumes locais das quais resultaram alterações da paisagem sociocultural de Umuofia. A vitória do modelo europeu provocou um conflito permanente de aceitação e rejeição, por exemplo, ao nível religioso, tal como sugere o diálogo que a seguir transcrevemos:

"Dizes que há um Deus supremo que fez o céu e a terra-Disse Akuna. Também acreditamos Nele e chamamos-Lhe Chukwu. Foi ele quem fez todo o mundo e os outros deuses". 
"Não existem outros deuses - disse o Sr. Brown. - Chukwu é o único deus e todos os outros são falsos" (in Achebe, 2008 (1958): 155-156).

Ao inserir as vozes da memória social local, Achebe liberta, de forma metafórica, a sociedade igbo da visão marcada pela miopia seletiva da historiografia ocidental, ou seja, da visão parcial da história que oculta(va) a riqueza da estrutura do tecido sociocultural dos povos não ocidentais. Ao incorporar essa riqueza, feita, sobretudo, através das marcas linguísticas locais, da exaltação da matriz sociocultural igbo e por via da estrutura do romance centrada na figura de Okonkwo, o herói igbo, Achebe põe em evidência a possibilidade de os elementos identitários igbo constituírem, tal como os seus congéneres europeus, matéria-prima para a conceção do texto literário. No dizer de Pires Laranjeira (2008: 183), a história de Okonkwo, o herói da tribo marginalizada, não podendo ser escutada no capítulo da história ocidental, foi retirada aos igbo por Achebe e, ao colocá-la no seu romance, este tornou-a universal.

Por conseguinte, entender Quando Tudo Se Desmorona implica escrutinar, ao abrigo de uma hermenêutica diatópica dos factos históricos, os elementos estruturantes do contradiscurso patente no romance. Isto pressupõe uma "desfiliação" do texto relativamente às matrizes do centro e a consequente localização do mesmo no espaço metonímico onde se situa o imaginário "achebiano". Essa "desfiliação" deverá ser tida como o ponto de partida para a projeção do texto para um macro-universo, do qual, com as suas peculiaridades histórico-culturais, também dele faz parte por direito. Desta forma, a narrativa constitui uma zona de contacto entre a periferia e o centro, promotora de um ambiente dialógico no qual as línguas e culturas representativas desses espaços partilham a mesma plataforma. Ao promover o encontro de vozes e de línguas, Achebe projeta a ligação do texto a um contexto sociocultural determinado, ao mesmo tempo que difunde a sua matriz (trans)cultural para uma rede global de leitores. A oposição direta entre elementos identitários, como, por exemplo, as culturas e as línguas, pode ser lida como uma das formas de remoção das não ocidentais da posição periférica que lhes foi atribuída, colocando-as, assim, em paralelo com as suas homólogas europeias. No entanto, Ngungi Wa Thiong'o, a partir de uma perspetiva diacrónica, ressalta as distintas funções das línguas europeias, a nível do continente africano. Na óptica de Thiong’o (2006 [1986]: 19),

O inglês, o francês e o português tornaram-se as línguas através das quais os africanos apresentaram as suas frentes nacionalistas contra os seus opressores. Após as independências essas línguas continuam a funcionar como fatores de união. Contudo, Achebe lembra ao seus leitores que a língua inglesa será capaz de carregar o peso da experiência africana. Mas terá de ser uma 'nova' língua inglesa 
que, embora permaneça ligada a sua terra ancestral, é no entanto alterada para estar em consonância com a realidade dos seus novos contextos africanos.

Nessa conformidade, Achebe põe ao dispor dos seus leitores uma escrita subversiva que, no dizer de Inocência Mata (2008: 111),

Vai minando a língua inglesa na sua ontologia etnocêntrica, disseminando nela a cultura igbo, através da utilização de recursos linguísticos pertencentes ao vocabulário da mesma e da exaltação da sabedoria popular oral, expressa em provérbios que pontuam as falas das suas personagens.

Ainda a respeito da coabitação lexical (anglo-igbo), Harry Garuba (2009: 248-249) enfatiza que, embora essa coabitação permita a inclusão de uma matriz africana, o maior foco do trabalho criativo de Achebe reside no modo como o autor se apropria dos recursos da oralidade, expandindo-os e reconfigurando-os, transformando-os, deste modo, em artefactos literários. No dizer de Garuba (idem, ibidem), mais do que uma mera reflexão acerca do paradigma da oralidade, o ponto conceptual almejado por Achebe consiste num processo de mediação, transformação ou de sedimentação do repertório da oralidade, sendo este o elemento caracterizador da relação entre o autor e a sua tradição oral.

Mala Pandurang (2009: 347) admite que, embora tivesse predecessores como The Palm Wine Drinkard (1953)12 , escrito por Amos Tutuola, Quando Tudo se Desmorona (1958), de Achebe, foi a primeira obra a ser aclamada internacionalmente, inspirando uma primeira geração inteira de escritores africanos a apropriarem-se da língua inglesa, incorporando nela, com fins políticos, técnicas de oratura e conjuntos lexicais africanos, demonstrando a sua mestria na "africanização" da língua colonial. Esta tipologia de escrita estava alicerçada numa urgência de afirmação e de recuperação identitária em distintas partes do continente africano face à severa negação da psique humana da África Negra (idem, ibidem). A presença da língua inglesa no seio dos igbo pode, na nossa perspetiva, funcionar como uma metáfora que alude à viagem por eles operada em direção ao modelo britânico, um percurso fortemente recusado por Okonkwo. Okonkwo expressa o seu inconformismo pelo facto de o seu povo se ter resignado à nova realidade e não ter lutado pela sua terra e pelas suas crenças, fazendo-o de uma forma trágica, cometendo o suicídio. Ao optar por essa via, Okonkwo acabou por violar as leis igbo e, por esse facto, não foi merecedor de um funeral a preceito e nem podia ser sepultado por nativos de Umuofia. Assim sendo, paradoxalmente, apenas aqueles que ele para a coleção Vozes de África do INALD, e, em São Paulo, pelo Círculo do Livro, em 1970, com o mesmo título. 
tentou combater estavam "legalmente" habilitados a fazer o seu funeral. Como podemos ler no romance:

"Aquele era um dos homens mais valorosos de Umuofia. Vocês levaram-no ao suicídio e agora será enterrado como um cão, disse Obierika".

"É um ato impensável um homem pôr fim à sua vida. É uma ofensa à terra e o homem que o pratica não será enterrado pelos membros do seu clã. O seu corpo é maligno e apenas estranhos lhe podem tocar" (in Achebe, 2008 (1958): 176).

Assim, ao descrever a trajetória do herói igbo, a natureza dos conflitos sociais e psicológicos desenvolvidos em Umuofia, durante os períodos pré e pós-colonial, Achebe convoca a memória ostracizada pela história resultante da visão autorizada pelo centro, para a reelaboração de uma (inter)historicidade abrangente, a partir de um exercício de reescrita da história, baseado numa hermenêutica diatópica e dialógica dos factos históricos, evocando, para o efeito, marcos da identidade igbo. A obra articula conflitos subjetivos e aspirações coletivas num sincretismo dialógico que reproduz as vozes e falas de todos os ocupantes do ambiente carnavalesco e transcultural do romance, dando ao leitor notas marcantes do espaço de pertença da obra ou, se preferirmos, da sua mundanidade, usando um conceito de Said (1975 [1983]).

\section{Conclusão}

A leitura do romance de Achebe, feita a partir de uma perspetiva crítica pós-colonial induz-nos a uma reflexão em torno do papel da literatura na produção de alternativas ao discurso "oficial" do centro, pois, como nos recorda Huggan (2001: 40), a literatura africana, tal como outras pós-coloniais, é, em termos genéricos, portadora de uma dimensão, simultaneamente, recuperadora e desconstrutora da identidade cultural e das expectativas ocidentais, respetivamente. Para tal, ela trabalha no sentido do desmantelamento das formas que privilegiam a supremacia do mundo ocidental. Obras como Quando Tudo se Desmorona funcionam, de certo modo, como contradiscursos, ou se preferimos, como contranarrativas etnográficas que elaboram o escrutínio dos questionáveis axiomas subjacentes às descrições antropológicas do ocidente, relativamente às culturas não ocidentais (idem: 41). Para o efeito, no seu romance, Achebe procede à re-leitura dos textos da história, revelando ligações entre os mesmos e o processo colonial, numa ótica "marginal", diferenciada daquela produzida a partir do centro, prestando, como diz Thomas Bonnici (2005), atenção às lacunas, às ironias e aos silêncios, bem como às metáforas do texto canónico. De facto, Achebe efetua uma releitura do texto canónico a partir do rastreio e da audição de várias histórias, fundamentalmente aquelas colocadas à margem da biblioteca oficial (Mata, 2012: 39). Assim, ao serem exercitadas 
pelo autor, a re-leitura e a re-escrita da história permitem a eclosão de um novo texto que problematiza e questiona o texto da biblioteca oficial. Por este facto, partilhamos a perspetiva de Mata (2012: 39-40) quando considera que a literatura equivale também a um registo histórico, onde o pré-colonial funciona como lugar da memória e as cicatrizes da colonização, a nível cultural, como pedra angular da re-construção identitária.

Em resumo, recorrendo ao labor literário, Achebe reabilita a história silenciada, concebendo um discurso que, do ponto de vista temático-lexical, se afasta das propostas ocidentais relativas ao registo e à divulgação de factos históricos, lembrando aos seus leitores que, não obstante as alterações profundas ocorridas na idiossincrasia igbo e o ostracismo a que foi relegada, a história dos núcleos fundacionais dos igbo subsiste viva na memória coletiva dessa comunidade

A terminar, diríamos que o romance Quando Tudo Se Desmorona constitui um exercício pleno de reescrita da história, sendo, portanto, de considerar o romance como um contributo à efetivação da inter-histocidade pelo facto de representar um pungente retrato literário de parte da história africana. O romance de Achebe aqui analisado convida-nos à reflexão sobre a natureza do recontro colonial e remete-nos para uma atmosfera que, dados os estereótipos construídos pela história e o contradiscurso produzido em resposta à versão ocidentalizada da história, nos diz que o futuro jamais será igual ao passado.

\section{Referências bibliográficas}

ACHEBE, Chinua (2008 [1958]), Quando Tudo Se Desmorona, Luanda, Instituto Angolano do Livro e do Disco.

ASHCROFT, Bill, AHLUWALIA, Pal (2001), Edward Said, London and New York, Routledge. ASHCROFT, Bill, GRIFFITHS, Gareth, TIFFIN, Helen (2004 [1998]) (orgs.), The Post Colonial Studies Key Concepts, London and New York, Routledge.

BAKHTIN, Mikhail (1984 [1963]), Problems of Dostoevsky's Poetics, History and Theory of Literature, vol. 8., Manchester, Manchester University Press.

BAKHTIN, Mikhail (1998 [1981]), The Dialogic Imagination, Texas,The University of Texas Press.

BONNICI, Thomas (2005), "Avanços e Ambiguidades do Pós-colonialismo no Limiar do Século 21”, Légua \& Meia: Revista de Literatura e Diversidade Cultural, 4 (3), pp. 186-202 [Online], disponível em: http://www2.uefs.br/leguaemeia/3/3_186-202_avancos.pdf [consultado em: 09/04/2017].

GARRUBA, Harry (2009), “The Critical Reception of African Novel”, in F. I. Abiola (org.), The Cambridge Companion to the African Novel, Cambridge and New York, Cambridge University Press, pp. 243-262.

GOMES, Catarina, MENESES, Maria Paula (2011), "História e Colonialismo: Por uma InterHistoricidade", Recueil Alexandries [Online], disponível em: www.reseau-terra.eu/article1223.html [consultado em: 12/04/2017]. 
HALBWACHS, Maurice (1992 [1950]), A Memória Colectiva, São Paulo, Edições Vértice/ Editora Revista dos Tribunais.

HUGGAN, Graham (2001), The Post-Colonial Exotic: Marketing the margins, London and New York, Routledge.

LARANJEIRA, Pires (2008), “Things Fall Apart: A mudança no mundo igbo" in D. Burness, I. Mata e V. Hartnack (orgs.), When Things Came Together: Studies on Chinua Achebe, Lisboa, Faculdade de Letras da Universidade de Lisboa, pp. 174-183.

MATA, Inocência (2008), "O Problema de Umuofia” in D. Burness, I. Mata e V. Hartnack (orgs.), When Things Came Togheder: Studies on Chinua Achebe, Lisboa, Faculdade de Letras da Universidade de Lisboa, pp. 103-133.

MATA, Inocência (2012), "Memória da Colonização e a Sentença do Futuro na Figuração da Nação: de Castro Soromenho a Leonel Cosme e Pepetela”, in A. M. Leite, H. Owen, R. Chaves e L. Apa (orgs.), Nação e Narrativa Pós- Colonial: Angola e Moçambique, Ensaios, Vol. I, Lisboa, Edições Colibri, pp. 37-56.

PANDURANG, Mala (2009), "Chinua Achebe and African Experience: A socio-literary perspective” in F. I. Abiola (ed.), A Norton Critical Edition: Chinua Achebe Things Fall Apart - Authoritative Text, Context and Criticism, New York and London, W.W. Norton, pp. 343-358.

PERALTA, Elsa (2007), “Abordagens Teóricas ao Estudo da Memória Social: Resenha Crítica”, Arquivos da Memória: Antropologia, Escala e Memória, 2 (Nova Série), Centro de Estudos de Etnologia Portuguesa, pp. 4-23 [Online], disponível em: www.fcsh.unl.pt/revistas/arquivos-da-memória/ArtPDF/02_Elsa_Peralta[1].pdf consultado em: 10/04/2017].

SAID, Edward (1983 [1975]), The World, The Text and the Critic, Cambridge and Harvard, Harvard University Press.

SOBRAL, José Manuel (2006), "Memória e Identidade Nacional: Considerações de carácter geral e o caso português", Working Papers, WP4-06 [Online], disponível em: http://www. ics.ul.pt/publicacoes/workingpapers/wp2006/wp2006_4.pdf [consultado em: 24/06/2015].

THIONG'O, Ngügï wa (2006 [1986]), Decolonising the Mind: The politics of language in African literature, Nairobi, Oxford and Portsmouth, East African Educational Publishers.

WELSCH, Wolfgang (1999), "Transculturality: The Puzzling of Cultures Today", in M. Featherstone e S. Lash (eds.), Spaces of Culture: City, Nation, World, London, Sage, pp. 194-213. 
Costa,André Oliveira - Norbert Elias e a configuração: Um conceito interdisciplinar. Configurações, vol. 19, 2017, pp. 32-47

\title{
Norbert Elias e a configuração: Um conceito interdisciplinar
}

\author{
ANDRÉ OLIVEIRA COSTA* \\ Faculdade de Filosofia, Letras e Ciências Humanas \\ Universidade de São Paulo, Brasil
}

\begin{abstract}
Resumo
Este artigo se propõe a pensar o conceito de configuração, tal como ele é desenvolvido pelo sociólogo Norbert Elias, como um elemento metodológico para um pensamento interdisciplinar. Nessa perspectiva, os conceitos de interdependência e poder são vistos como centrais para a articulação entre diferentes campos. No projeto eliasiano de suspender a antítese entre indivíduo e sociedade, o processo civilizador imbrica a sociogênese e a psicogênese. A interdisciplinaridade encontra-se na base desse processo, na medida em que ela trata sobre a formação dos indivíduos através da aprendizagem das regras e normas sociais.
\end{abstract}

Palavras-chave: configuração, processo civilizador, interdependência, poder.

\begin{abstract}
Norbert Elias and configuration: an interdisciplinary concept.

This paper intends to address the concept of configuration, as it is developed by the sociologist Norbert Elias, as a methodological element for an interdisciplinary thought. In this perspective, the concepts of interdependence and power are seen as central for the articulation between different fields. In the Eliasien project of suspending the antithesis between individual and society, the civilising process imbricates sociogenesis and psychogenesis. Interdisciplinarity is the basis of this process, in that it deals with the training of individuals by learning the rules and social norms.
\end{abstract}

Keywords: configuration, civilising process, interdependence, power.

*Diversitas - Núcleo de Estudos das Diversidades, Intolerâncias e Conflitos; Fundação de Apoio à Pesquisa do Estado de São Paulo (FAPESP); E-mail: androlicos@gmail.com 


\section{Résumé \\ Norbert Elias et la configuration : un concept interdisciplinaire.}

Cet article se propose de penser le concept de configuration comme un élément méthodologique de réflexion interdisciplinaire, tel qu'il a été développé par le sociologue Norbert Elias. Dans cette perspective, les concepts d'interdépendance et de puissance sont considérés comme essentiels pour la relation entre les différentes sciences. Dans le projet éliasien de dépasser l'antithèse entre l'individu et la société, le processus civilisateur articule la sociogenèse et la psychogenèse. L'interdisciplinarité est à la base de ce processus, dans la mesure où il s'agit de la formation des individus par les règles et les normes sociales.

Mots-clés : configuration, processus civilisateur, interdépendance, puissance.

\section{Introdução}

Norbert Elias procurou desenvolver, durante toda sua trajetória intelectual, um pensamento que ultrapassa as fronteiras estabelecidas entre os campos de conhecimento, resistindo aos dualismos simplistas e às categorizações estereotipadas. Através da multiplicidade de assuntos e da diversidade de disciplinas com as quais dialoga, o sociólogo estende os limites da sociologia ao compreender que os processos sociológicos não existem em si mesmos, mas estão intimamente relacionados aos processos históricos, educacionais, psicológicos e biológicos (Delzescaux, 2001: 162). Nesse sentido, não se trata de pensar em estruturas sociais estáticas, mas de considerá-las sempre em desenvolvimento a longo prazo, tampouco de considerar ações sociais como individuais, pois o indivíduo deve ser inscrito dentro de uma rede de relações. Sua sociologia, dessa forma, se transforma em uma sociogênese, cujas bases concomitantemente constituem a psicogênese dos indivíduos.

Neste artigo, nos propomos a investigar como Norbert Elias situa o conceito de configuração como elemento fundamental em seu projeto de ruptura do pensamento fragmentário, buscando pensar uma articulação interdisciplinar entre diferentes campos de conhecimento. Nessa perspectiva, a tese sobre o processo civilizador permite ultrapassar o princípio que sustenta que os indivíduos são entidades fechadas e autônomas. Em relação ao indivíduo e à coletividade, nenhum desses termos deve ser considerado completo, mas em constante processo de transformação; não devem ser considerados em seu tempo presente, mas devem ser sempre vistos a longo prazo.

As análises de Norbert Elias em A Sociedade de Corte serão utilizadas como exemplo para apresentar o conceito de configuração como um operador metodológico, que é aplicado ao campo da sociologia, mas que toma emprestado elementos de outras disciplinas para compreender o ser humano dentro de uma rede de relações e interdependências. Assim, pretendemos mostrar como a configuração serve para articular áreas como educação, história, sociologia e 
psicanálise. Dessa maneira, não podemos pensar o indivíduo sem estar inscrito simbolicamente em uma rede social, nem a sociedade sem o recalcamento das pulsões e afetos.

Lemos Elias compreendendo que ele se afasta de certas posições tradicionais: a metafísica, que substancializa os seres como se eles existissem de forma autônoma e independente; a dualista, que pensa as relações como se fossem dicotomias expressas em termos de causa e efeito, sujeito e objeto, interior e exterior; a teleológica, que vê os processos como se fossem a evolução em vista da realização de um fim determinado; a normativa, que visa uma cientificidade na qual o próprio investigador se considera excluído de seu objeto de pesquisa; a da causalidade, que precisa correlacionar a formação de efeitos na necessariedade mecanicista de uma causa; e a fragmentária, que pensa o mundo de forma descontínua, constituído por elementos encerrados em sua particularidade.

\section{A configuração da sociedade de corte}

A pesquisa que Elias desenvolveu em Frankfurt na década de 1930 foi publicada 30 anos mais tarde, com o título A Sociedade de Corte: Investigação sobre a sociologia da realeza e da aristocracia de corte. Trata-se de um trabalho interdisciplinar, marcado pela história, na medida em que estuda a corte francesa do Ancien Régime entre os reis Francisco I e Luís XIV; pela sociologia, na medida em que sua análise não se refere à corte, mas à sociedade de corte enquanto formação social configurada por sujeitos em interdependência e à função social do rei e de suas relações; pela psicologia, na medida em que ele trata sobre o desenvolvimento e o controle da economia psíquica dos indivíduos; e pela educação através da formação de hábitos e comportamentos. Vejamos como na configuração da sociedade de corte estão imbricadas a sociologia, a educação e a psicanálise.

Em A Sociedade de Corte, Elias apresenta alguns dos conceitos fundamentais de sua obra, como configuração, interdependência e equilíbrio das tensões. Dentre eles, destacamos o conceito de configuração como central, pois ele possibilita a reformulação até mesmo do próprio significado de sociologia. A teoria eliasiana, nesse sentido, é considerada uma sociologia configuracional. Afirma Elias (2001b: 213): “uma das questões centrais da sociologia, talvez a questão central, seja saber de que modo e por que os indivíduos estão ligados entre si, constituindo, assim, configurações dinâmicas específicas". Através do conceito de configuração, Elias consegue ultrapassar o pensamento que sustenta o antagonismo entre indivíduo e a sociedade, como se fossem estruturas autônomas e independentes, um ente indivisível e a uma superestrutura formada por um conjunto de elementos isolados, respectivamente. No segundo volume de O Processo Civilizador, Elias faz uma descrição da configuração 
como o elemento articulador da sociologia com outros campos de investigação. Trata-se de uma referência que merece ser longamente citada, na medida em que fornece as diretrizes para a pensar inter-relação entre disciplinas:

A fim de entender estruturas e processos sociais, nunca é suficiente estudar um único estrato funcional no campo social. Para serem realmente entendidas, essas estruturas e processos exigem um estudo das relações entre os diferentes estratos funcionais que convivem juntos no campo social e que, com a mais rápida ou mais lenta mudança nas relações de poder provocadas por uma estrutura específica desse campo, são no curso do tempo reproduzidas sucessivas vezes. Da mesma forma que em todo estudo psicogenético é necessário levar em conta não só as funções "inconscientes" e "conscientes”, mas a contínua circulação de impulsos entre umas e outras, igualmente é importante, em todos os estudos sociogenéticos, levar em conta desde o princípio toda a configuração do campo social, que é mais ou menos diferenciado e carregado de tensões (Elias, 1993: 239).

Para Elias, a sociedade de corte constitui uma configuração, pois se mostra como uma estrutura social em constante processo de transformação e que é composta por elementos interdependentes entre si. A sociedade de corte, tal como podemos ver na corte do rei Luís XIV, não é um fenômeno que se encontra fora dos indivíduos, da mesma forma que eles não conseguiriam reconhecer o sentido de suas vidas fora dela. O conceito de configuração desalinha as fronteiras entre público e privado, desarruma as diferenças entre social e psíquico.

Parte-se, assim, do princípio que conceitos como "indivíduo" e "sociedade" não são estáticos, pois estão sempre sofrendo transformações; que eles se diferenciam, mas são elementos de uma mesma estrutura. Elias, com isso, abre caminho para a compreensão da formação dos indivíduos através do lugar social que eles ocupam, de suas relações com as normas e as regras que organizam os grupos sociais, considerando o processo de internalização e constrangimento das pulsões e emoções de cada um. Apesar de Elias, em A Sociedade de Corte, não fazer referência ao pensamento de Freud, sabemos que, na época de sua escrita, ele já estava às voltas com a psicanálise (Joly, 2010) na tentativa de imbricar a sociogênese, que se refere aos processos de formação de determinada configuração social, com a psicogênese, que diz respeito à economia psíquica, à transformação dos comportamentos e das estruturas da personalidade.

Elias quer se distanciar de certas posições teóricas que partem do pressuposto de que o "sujeito" é separado da "natureza” ou dos "objetos. Essas teorias não consideram, como ele nos indica, que a formação de uma "instância de controle mais ou menos automatizada pelo hábito e pela educação se intercala, sob o nome de reflexão, entre o homem e o objeto de conhecimento" (Elias, 2001b: 215). Entre indivíduo e cultura, o que vemos é a formação de uma estrutura simbólica que transforma muito lentamente as emoções e os comportamentos. A educação, nesse sentido, é, por excelência, um dos principais 
temas de Elias, na medida em que ele pensa os processos de formação dos indivíduos correlacionados com o processo de formação das estruturas sociais.

Em Norbert Elias e a Educação, Andréa Leão (2007) nos mostra como a obra do sociólogo está intimamente atravessada pela educação, na medida em que Elias trata o infantil, a formação da personalidade, a construção dos símbolos sociais, além do decoro corporal, do controle dos gestos, expressões faciais e emoções, da forma de olhar os outros e regular seus comportamentos. Segundo a autora (idem), a civilização é efeito de um processo no qual o universo simbólico infantil começou a se diferenciar da esfera social dos adultos. A leitura de manuais de comportamento, que tratavam sobre a importância da etiqueta e da cerimônia na formação do caráter, foram fundamentais na nova configuração da corte francesa, na medida em que regulavam o comportamento infantil e faziam de suas leituras uma forma de conversação sobre técnicas de autocontrole e disciplina.

No posfácio "Freud, Elias e a ciência do homem”, publicado no livro Au-delà de Freud: Sociologie, psychologie, psychanalyse, Bernard Lahire (2010) nos aponta como Elias se aproxima da psicanálise freudiana a fim de buscar a historicização de seus conceitos, visto que, mesmo reconhecendo a importância da psicanálise, uma das críticas que Elias teceu ao pensamento de Freud foi não ter considerado os efeitos das transformações sociais ao longo da história no desenvolvimento da estrutura psíquica. Para Elias (2010), Freud concebeu as instâncias psíquicas como se fossem estáticas e universais, isto é, como se o supereu, o eu e o isso estivessem presentes no psiquismo do ser humano desde sua origem.

De acordo com Roger Chartier (2001), no prefácio que escreveu à obra $A$ Sociedade de Corte, a função do sociólogo, tal como a propõe Elias, é identificar e compreender as formações sociais ao longo dos tempos, ou seja, realizar uma análise das configurações. Isso significa tomar como referência três escopos de desenvolvimento: a evolução biológica, a evolução social e a evolução vivida na escala da história individual (Chartier, 2001). No caso das sociedades de corte, esses critérios possibilitam compreender como as tensões entre as forças de diferentes grupos sociais (a burguesia e a aristocracia) conduziram a sociedade de corte a um processo em que o Estado se coloca como o responsável pelo monopólio da violência, contra as forças corporais das pulsões e a espontaneidade das emoções e dos afetos.

Também estamos de acordo com Chartier quando ele nota que o conceito de configuração carrega consigo paradoxos e contradições formados pelos encontros de pensamentos diferenciados. No caso da sociedade de corte, segundo o autor, o conceito de configuração apresenta três paradoxos. O primeiro surge quando novas proibições são impostas de fora, transformando a economia psíquica e inscrevendo maior autocontrole sobre as pulsões e as emoções. É o paradoxo da proximidade e distância. É ele que produz a indefinição 
entre os espaços da vida pública e a vida privada. Afirma o autor: "Inicialmente, a sociedade de corte é uma configuração em que a maior distância social se manifesta na maior proximidade espacial" (Chartier, 2001: 20). Isso faz com que o rei inscreva uma distância no seio da nobreza. Elias identifica esse paradoxo através da análise das habitações das elites parisienses, mostrando como os hotéis particulares da aristocracia refletiam as relações interpessoais entre o marido e a esposa, entre os mestres e os serviçais.

O segundo princípio paradoxal dessa nova formação social é o da redução da identidade à aparência. O ser de um indivíduo é definido pela representação que ele ocupa dentro da rede de relações sociais. Como efeito dessa imbricação entre ser e parecer, a educação através da etiqueta estabelece o modelo das formações de personalidade. De acordo com Chartier (idem: 21): “em uma tal formação, a construção da identidade de cada indivíduo está sempre no cruzamento da representação que faz de si mesmo e da credibilidade concedida ou recusada pelos outros a essa representação”. Nesse sentido, Elias dedica um capítulo para falar sobre a etiqueta e o cerimonial, notando que os gestos, os hábitos e os comportamentos da corte inscreviam modos particulares de existência.

A arte de observar pessoas e a arte de lidar com pessoas condicionam a mentalidade e as emoções. Surge uma nova forma de ser e de pensar, conforme Elias (2001b: 126): “Aquilo que é 'racional' depende sempre da estrutura da sociedade. O que denominamos objetivamente 'razão', ou ratio, vem à tona sempre que a adaptação a uma determinada sociedade e a sobrevivência dentro dela demanda uma precaução ou cálculo específico". Esse novo pensamento, reflexo das exigências e das regras sociais, leva a uma nova economia psíquica, de controle e retração das emoções: "A estrutura da vida social dentro dessa configuração deixa um espaço mínimo, comparativamente, para as manifestações afetivas espontâneas" (idem, ibidem).

E o terceiro paradoxo que fundamenta a configuração da sociedade de corte, segundo Chartier, diz respeito à relação entre superioridade e submissão. A superioridade da posição social se fundamenta nas submissões política e simbólica. Indivíduos pertencentes à sociedade de corte estão submetidos à regras e normas específicas, que não são as mesmas que organizam a burguesia. As formações reguladoras e a etiqueta são elementos que possibilitam a diferenciação entre as classes sociais: "Com a etiqueta, a sociedade de corte procede à sua autorrepresentação, cada pessoa singular distinguindo-se de cada uma das outras e todas elas se distinguindo conjuntamente em relação aos estranhos ao grupo" (Elias, 2001b: 120). Dentro da sociedade de corte, então, a educação pela formalidade dos comportamentos cerimoniais, com regras e costumes que se impõem sobre os pequenos gestos e olhares, associa os indivíduos em diferentes configurações, através do controle dos afetos e das emoções, e os distingue da burguesia e das classes mais pobres. 
Contudo, até mesmo o rei está preso às obrigações da etiqueta e dos cerimoniais, conforme Elias se dedica a analisar em um dos capítulos de $A$ Sociedade de Corte. Os símbolos sociais da corte transmitidos pela educação ao citoyen das elites aristocráticas fundaram configurações que visavam um maior distanciamento entre as classes sociais, o apreço pelos detalhes dos gestos, o pensamento racional e o controle das emoções. Mas, se, para o rei Luís XIV, a etiqueta tinha valor de dominação, também o soberano estava inscrito em uma rede de interdependências. A configuração de dominação, que inscreveu na corte um "fetiche de prestígio", colocou o rei no aprisionamento de sua própria imagem, sendo obrigado não apenas a exercer, mas também a demonstrar publicamente seu poder através de atos simbólicos de assujeitamento dos outros. Afirma Elias (2001b: 149):

A violenta reivindicação de importância e a necessidade de glorificar a própria existência como soberano, que aparentemente o elevavam acima de todos os outros homens, acabavam ao mesmo tempo prendendo o rei em correntes que o empurravam inexoravelmente para dentro da engrenagem social.

O paradoxo das relações de interdependência da sociedade de corte se mostra de maneira mais efetiva no equilíbrio de forças que o soberano deve exercer: para ter mais poder, mais liberdade individual, mais dependente ele se torna dos instrumentos de dominação, mais ele perde seu espaço privado. Através da análise da sociedade de corte, entre suas tensões e jogos de poder, fica evidente que o conceito de configuração ultrapassa a ideia de sistema, na medida em que ele não evoca a ideia de uma entidade totalmente fechada, nem a de uma harmonia imanente. $\mathrm{O}$ conceito de configuração pode fazer referência a relações mais ou menos estáveis, pacíficas e amigáveis entre as pessoas, assim como a relações hostis e prestes a se romper. Por isso, Elias não se limita a estudar as formações sociais estabelecidas, mas vai em busca de desequilíbrios, de situações de violência, de solidão e morte.

\section{Os fundamentos da configuração: interdependência e poder}

No texto A Sociedade dos Indivíduos, escrito em 1939, mas publicado apenas em 1987, Elias apresenta um dos principais objetivos de suas investigações, a saber, superar a oposição que o pensamento moderno estabeleceu entre o indivíduo e o mundo, determinando-os como termos opostos e inconciliáveis. Sua proposta é se afastar do muro intransponível entre indivíduo e sociedade. Elias (1994: 18) escreve: "Mas e se uma compreensão melhor da relação entre indivíduo e sociedade só pudesse ser atingida pelo rompimento dessa alternativa ou isto/ou aquilo, desarticulando a antítese cristalizada?”. 
Elias busca compreender esses termos através do processo civilizador, pela qual eles são tratados em imbricação mútua. Nem indivíduo, nem sociedade. Para o sociólogo (idem, ibidem): “considerados num nível mais profundo, tanto os indivíduos quanto a sociedade conjuntamente formada por eles são igualmente desprovidos de objetivo. Nenhum dos dois existe sem o outro”. O ser humano nasce dentro de um contexto cultural e familiar, em uma rede de associações pré-existente a ele. Cada pessoa surge como uma função dentro de uma configuração, na qual as outras pessoas agem igualmente como funções, de modo que cada um se constitui através do outro.

Dessa forma, em A Sociedade dos Indivíduos, já encontramos o projeto de uma sociologia não dualista: "liberar o pensamento da compulsão de compreender os dois termos [indivíduo e sociedade] como opostos" (Elias, 1994: 7). O pensamento eliasiano como um todo vai contra a ideia de uma totalidade de unidades, considerando impossível pensar os indivíduos como indissociáveis dos laços sociais, como unidades isoladas de qualquer relação que possam estabelecer com os outros, assim como impedindo de conceber a sociedade como resultante de um agrupamento de seus membros, como entidades supra-individuais, exteriores e separadas dos indivíduos. Sua proposta é, justamente, criticar as concepções que se apoiam nesta divisão entre a centralização psicológica e as estruturas sociais.

Norbert Elias opõe-se fortemente ao pensamento que introduz uma barreira entre indivíduo e sociedade e que configura esses termos, por vezes um ou outro, como elementos reais ou irreais, cujas existências seriam separadas uma das outras, entidades autônomas, livres e com maior valor que a outra. Para ele, termos como indivíduo e sociedade são “aspectos diferentes, embora inseparáveis, dos mesmos seres humanos, e que ambos os aspectos (e os seres humanos em geral) habitualmente participam de um processo de transformação estrutural” (Elias, 1990: 220).

A intenção de suspender a separação entre indivíduo e sociedade é reafirmada na introdução do livro A Sociedade de Corte:

Os conceitos de "indivíduo" e "sociedade" geralmente são usados como se dissessem respeito a duas substâncias distintas e estáveis. Por esse uso das palavras, é fácil ter a impressão de que elas designam objetos não só distintos, mas absolutamente independentes em sua existência. Mas na realidade designam processos. Trata-se de processos que de fato se diferenciam, mas são indissociáveis (Elias, 2001b: 45).

Essa divisão inscreve diferentes posições a respeito dessa relação, que tem consequências éticas e políticas no comportamento daqueles que acabam adotando um dos lados. Seja no campo da educação, da psicologia ou da história, o indivíduo, muitas vezes, aparece existindo fora da sociedade, de maneira 
autônoma e independente, recebendo destaque sobre o coletivo. O indivíduo da filosofia, por exemplo, existe a priori e em excelência. Ele não passou pelo processo de desenvolvimento próprio da natureza humana e de sua sociedade. É o homo philosophicus que, olhado mais atentamente, pode ser encontrado em diferentes versões, segundo as diferentes ciências: o homo œconomicus, o homo psychologicus, o homo sociologicus e o homo podagogicus. São personagens, acima de tudo, ideais, estáticas e universalmente replicáveis. Outras vezes, a sociedade também aparece como existindo fora do indivíduo, autônoma e independente. Por exemplo, quando o Estado impõe-se sobre o indivíduo ao exigir dele a obrigatoriedade de entregar sua própria vida diante de um contexto de guerra, ou quando impõe leis que arbitram e regulam a vida privada de cada um, anulando a liberdade individual e as possibilidades de fazer escolhas próprias.

Nessa lógica, buscar-se-ia pensar quem estaria dentro e quem estaria fora, quem seria maior, quem seria menor, onde está a causa e onde está o efeito. A princípio, parecem restar apenas essas duas escolhas. Considerar o indivíduo como o que existe realmente, fechado em si mesmo, para além da sociedade, que seria mera abstração; ou a sociedade caracterizada como uma totalidade, um sistema externo com regras e funcionamento próprios, cuja realidade ultrapassa a abstração do indivíduo. Mas, seguindo o pensamento de Elias, não devemos pensar em entidades, mas em configurações; não se trata de civilização, mas de processo civilizador.

Elias também não pensa a sociedade como tendo contornos nítidos, completa em si mesma, com todas suas estruturas visíveis. De acordo com o sociólogo: "consideradas como totalidades, [as estruturas] são sempre mais ou menos incompletas: de onde quer que sejam vistas, continuam em aberto na esfera temporal em direção ao passado e ao futuro" (Elias, 1994: 20). Conceber a incompletude da estrutura social, entretanto, não conduz à conclusão de que não haja regras ou ordem. Dentro desse desequilíbrio, cada pessoa assume um determinado lugar, tem uma função, uma propriedade ou uma tarefa específica em relação aos outros.

Com o objetivo de ultrapassar a oposição estabelecida pelas ciências entre indivíduo e sociedade, Elias forja o conceito de configuração, escapando das abordagens que assumem uma dessas posições, tal como encontramos das ciências humanas em geral ou, na sociologia, nas proposições do individualismo de Max Weber e do holismo de Emile Durkheim (Colliot-Thélène, 2010; Blondel, 2001). Para Elias, essa divisão resulta da forma individualista do pensamento do mundo ocidental moderno. Mas, quando o pesquisador se desvencilha das amarras dessas posições, ele percebe que falar de indivíduo e sociedade é fazer referência a aspectos diferentes do mesmo objeto.

Além da suspensão da antítese indivíduo/sociedade, o conceito de configuração repercute-se nas ideias de causalidadelefeito e de poder. Segundo 
Florence Delmotte (2010), essas disjunções veiculam a falsa concepção da liberdade individual e do determinismo social. Nem um, nem outro. Nem o indivíduo é totalmente livre, nem totalmente determinado, seja por forças exteriores, seja por suas pulsões, desejos e interesses. Os indivíduos, antes mesmo de nascer, são dependentes de uma rede de associações que situa seu lugar em relação aos outros, assim como as sociedades, em suas estruturas, são formadas de ações resultantes desses indivíduos socializados. Afirma Delmotte (2010: 32):

Contam apenas as relações e as situações de interdependência que elas definem; contam apenas as interações - não necessariamente voluntárias, nem conscientes, nem mesmo concretamente interpessoais e menos ainda igualitárias -, que religam os homens aos que os entornam, de perto e de longe, aos que os precederam, aos que o sucederão.

No artigo intitulado Conceitos sociológicos fundamentais, Elias (2006) nos mostra que o conceito de configuração compreende a formação dos indivíduos na sua relação com os objetos simbólicos, com a transmissão da cultura e com o aprendizado de um patrimônio simbólico social. O indivíduo que não foi educado com símbolos de uma cultura, que não aprendeu uma língua ou que não inscreveu elementos sociais em seu processo de subjetivação não se desenvolve propriamente como um ser humano. Assim, devido à interdependência entre os indivíduos, mesmo em situações de desordem, caos, rompimentos ou desintegrações sociais, os indivíduos sempre acabam se agrupando em configurações específicas.

O indivíduo possui dentro da sociedade um papel que já lhe vem determinado anteriormente ao seu nascimento. Não lhe cabe absolutamente a escolha de mudar de posição. Elias (1994: 21) afirma: "Até sua liberdade de escolha entre as funções preexistentes é bastante limitada. Depende largamente do ponto em que ele nasce e cresce nessa teia humana, das funções e da situação de seus pais e, em consonância com isso, da escolarização que recebe". Os indivíduos constituem uma rede de laços invisíveis, cuja circulação é limitada e dependente das funções que podem exercem dentro da configuração. Essa associação não se constitui de relações entre indivíduos, mas de relações entre funções. As configurações, portanto, designam todo tipo de situação concreta de interdependência, desde um jogo de cartas até o funcionamento de uma nação.

O lugar em que uma criança ocupa dentro da rede das relações familiares, assim como a classe social a que ela pertence são exemplos de alguns dos fatores que contribuem para formar sua personalidade. Um indivíduo existe a partir das marcas simbólicas inscritas pelos outros com os quais ele se relaciona, mas também por sua capacidade de representar-se como alguém que 
pertence e ocupa uma determinada função dentro de uma coletividade: “Toda a maneira como o indivíduo se vê e se conduz em suas relações com os outros depende da estrutura da associação ou associações a respeito das quais ele aprende a dizer 'nós"' (Elias, 1994: 39). A proposta de Elias se desdobra na direção de conceber que os gestos e atos de uma criança não são efeitos de sua natureza interior, mas constituem uma função e um precipitado de relações.

Segundo Delmotte (2010), o conceito de configuração ainda traz consigo outra perspectiva além do rompimento com o princípio da causalidade/ efeito. Trata-se da ideia de poder, que marca toda sorte de funções dentro das relações entre as pessoas. O poder não é uma posse, algo que um indivíduo mais forte possui para domínio do mais fraco. Antes, ele é uma particularidade de todas as relações humanas. Por causa disso, Elias se interessa, em suas pesquisas, em estudar as forças que se encontram entre diferentes configurações: por exemplo, entre estabelecidos e outsiders, entre a aristocracia e a burguesia presentes na corte francesa, e entre a formação do Estado alemão e a Alemanha nazista.

Ao longo de sua obra, Elias recorre a diversas imagens para descrever o funcionamento das configurações. Em A Sociedade dos Indivíduos, a configuração é ilustrada através de uma rede de tecidos constituída por fios isolados que se ligam um ao outro, de modo que não se pode compreendê-la em sua unidade, nem em sua totalidade, mas nas relações recíprocas entre as partes. Em $O$ Processo Civilizador, ele exemplifica a interdependência funcional através das diferentes complexidades entre rotas e vias de comunicação de dois diferentes tipos de sociedade.

Mas é no livro Introdução à Sociologia, onde Elias utiliza as situações de jogos, como de carta ou de xadrez, que o conceito de configuração aparece entrelaçado com o de poder. A utilização dos modelos dos jogos pode ser aproximada das competições esportivas como uma forma de exemplificar o funcionamento da sociedade. Eles servem para explicar o entrelaçamento dos fins e das ações entre os homens, demonstrando, de um modo simplificado, o caráter relacional do poder que ocorre no entrelaçamento de funções em uma estrutura social. As ações operadas por cada função determinam os processos internos dessas estruturas, tal como num jogo de xadrez, em que os movimentos das peças vão traçando a história do movimento das jogadas que lhes sucedem. Assim, não é possível explicar as ações e os objetivos das funções se forem tomadas isoladamente, mas apenas na inter-relação que elas mantêm com outras funções. Dentro de uma competição, nenhuma jogada pode ser explicada isoladamente, mas apenas tendo em conta o modo como as jogadas anteriores resultaram na configuração das peças até aquele momento específico.

O conceito de função remete para o caráter relacional das ações dos indivíduos ordenadas pelo poder que eles exercem uns sobre os outros. A 
função não é "uma tarefa desempenhada por uma parte, dentro de uma 'totalidade' harmoniosa. O modelo dos jogos nos indica que, tal como o conceito de poder, o conceito de função deve ser compreendido como um conceito de relação" (Elias, 2008: 84). Para evitar a unilateralidade da função e, assim, não mais pensar através de implicações unilaterais, por exemplo, a sociedade determinando de fora as ações do indivíduo, Elias afirma que a função, por ser uma relação multivetorial, é o mútuo exercício de poder de um sobre o outro:

Dependemos dos outros; os outros dependem de nós. Na medida em que somos mais dependentes dos outros do que eles são de nós, em que somos mais dirigidos pelos outros do que eles são por nós, estes têm poder sobre nós, quer nos tenhamos tornado dependentes pela utilização que fizeram da força bruta ou pela necessidade que tínhamos de ser amados, pela necessidade de dinheiro, de cura, de estatuto, de uma carreira ou simplesmente de estímulo (Elias, 2008: 101).

O conceito de poder, para Elias (2008: 81), é “uma característica estrutural das relações humanas - de todas as relações humanas”. Ele é resultante do encontro das funções sociais. Não é um atributo que possa ser possuído por componentes isolados. Também não é característico exclusivamente das situações de dominação, tal como a do senhor e do escravo. Pelo contrário, ele assume variadas formas e se encontra em todos os níveis de relações - familiares, políticas, econômicas, religiosas. Uma criança, por exemplo, tem poder sobre os pais quando estes lhe atribuem um determinado valor, assim como um escravo também tem poder sobre o senhor ao deixá-lo dependente em suas necessidades. O poder é estrutural em uma relação e, por isso, não pode ser qualificado nem como bom, nem como mau.

Dessa forma, os jogadores singulares não têm total liberdade de escolha, na medida em que é o próprio processo do jogo que tem poder sobre as jogadas realizadas. Afirma Elias (2008: 104): “As suas ações e ideias não podem ser explicadas e compreendidas se forem consideradas em si mesmas; precisam ser compreendidas e explicadas no interior da estrutura do jogo". Contudo, uma determinada configuração, assim como ocorre com jogadores que disputam uma partida, também depara-se com o problema do acaso: "O processamento de um jogo, que surge inteiramente como um resultado de cruzamento de jogadas individuais de muitos jogadores, toma um rumo que não foi planejado, determinado ou pensado antecipadamente por nenhum dos jogadores individuais" (Elias, 2008: 103). O acaso das ações singulares e a contingência da própria configuração afastam o efeito de causalidade direta de um sobre o outro, como se supostamente mudando um, o outro também mudasse.

Para se afastar da concepção fragmentada não relacional entre os elementos de uma determinada configuração (seja qual for o grau de complexidade, como um jogo de cartas ou a sociedade de corte francesa do século XVI), é 
necessário abdicar dos recursos de linguagem utilizados pelas ciências modernas. A especificidade das teorias sociológicas - e poderíamos estendê-la para qualquer pensamento que investiga as relações humanas - resulta não do objeto sobre o qual nos debruçamos, mas dos conceitos em que nos apoiamos. O uso de determinadas palavras conduz a descrições que se restringem a relações de oposição: sujeito versus objeto, mundo interno versus mundo externo, eu versus outro, natureza versus cultura.

A linguagem, então, nos obriga a falar e a pensar como se esses elementos fossem entidades isoladas e estáticas, sem considerá-los em relações.

Assim ocorre também com termos como Estado, escola, família, criança e pessoa. Tomá-los como termos independentes afasta-os de quaisquer relações que eles estabeleçam, como se o comportamento de uma criança dissesse respeito apenas a ela própria e não fosse efeito do lugar que ela ocupa dentro de uma complexa rede de relações, ou como se os pais não precisassem ser condizentes com as determinações da sociedade e do Estado. O uso de certas palavras, especialmente em culturas altamente individualizadas, faz com que seus referentes sejam representados como elementos estáticos, autônomos e independentes. Elias (2008: 129) dá especial destaque aos pronomes pessoais como determinantes de certa posição subjetiva ao longo da história: "Somos levados a acreditar que o nosso 'eu' existe de certo modo 'dentro' de nós; e que há uma barreira invisível separando aquilo que está 'dentro’ daquilo que está 'fora' - o chamado 'mundo exterior'”.

Quando Elias considera importante o lugar que cada indivíduo assume dentro de uma estrutura de relações funcionais, pensamos que aí se encontra uma teoria que nos leva a compreender o indivíduo desde o lugar que ele responde às ações do outro. O pronome "eu" refere-se a uma pessoa no singular, enquanto o pronome "nós” a pessoas no plural. Mas é impossível fazer referência à pessoa singular excluída da pluralidade de suas relações. Assim, Elias questiona a barreira que encerra os seres humanos em entidades isoladas e independentes (homo clausus), para representá-los como diversos "eus" interdependentes, com valências abertas às teias sociais.

A utilização dos pronomes pessoais normalmente concede aos seus referentes a qualidade de substantivos. O pronome "eu", por exemplo, quando tratado como objeto de estudo, é transformado numa substância, em uma coisa independente. A psicologia experimental ou laboratorial, através das avaliações por testes psicológicos, considera alcançar as propriedades de um indivíduo como se ele fosse um ser autônomo e independente e, portanto, quantificável, universal e constante. Dessa forma, os outros pronomes, "tu", "ele" e "nós", estão para o primeiro como entidades outras. A crítica de Elias (2008: 134) recai novamente sobre o uso individualizante destes pronomes: “A função que o pronome 'eu' desempenha na comunicação humana só pode ser compreendida 
no contexto de todas as outras posições relativamente às quais se referem os outros termos da série".

Por outro lado, quando tratados como funções, no sentido de serem posições pelas quais os indivíduos exercem suas ações, os pronomes pessoais estão intrinsecamente relacionados, de forma que não se poderia pensar o "eu", sem os "tu", "ele" e "nós". Esses pronomes indicam o conjunto de coordenadas com as quais se representa as sociedades ou qualquer tipo de pluralidade humana. O "eu", desde onde se fala ao "tu", inclui-se no "nós" como seu coletivo, deixando para o "ele" a função que se encontra fora de seu grupo: "Os pronomes pessoais são no seu conjunto uma expressão elementar do fato de que cada um se relaciona fundamentalmente com os outros e de que cada ser humano individual é essencialmente um ser social” (Elias, 2008: 135). É impossível falar em "nós" sem conceber o "eu" desde onde o indivíduo se enuncia ao "ele".

São posições básicas que situam as relações das diversas configurações, seja daquele que fala "por si" ou "pelo grupo" ao qual pertence. Isso indica que o indivíduo singular se refere a uma pessoa em relações de interdependência e a sociedade ao conjunto de pessoas em relações de interdependência. Assim, com a utilização dos pronomes pessoais como modelo para pensar as configurações, compreendemos como é possível pensar uma distinção entre as pesquisas sobre pessoas no singular e as pesquisas sobre pessoas no plural, mas é impossível a sua separação, "tal como as pessoas no singular não podem ser separadas das pessoas no plural” (idem: ibidem).

\section{Considerações finais}

O conceito de configuração é uma estratégia metodológica que possibilita escapar dos ideais e das crenças pelos quais os diversos campos de conhecimento estão capturados, fragmentando e polarizando a dimensão humana. A configuração alarga os campos e os coloca em relação estreita com outras disciplinas, como a sociologia se volta para a educação, a história e a psicologia. Se tivermos que buscar um adjetivo para qualificar a sociologia de Norbert Elias, devemos necessariamente passar pelo conceito de configuração, na medida em que é através dele que Elias dá sentido à realidade. Mas denominar seu pensamento de sociologia das configurações é também determiná-la como uma sociologia dos processos:

Este pode ser aplicado tanto a grupos relativamente pequenos como a sociedades constituídas por milhares ou milhões de pessoas interdependentes. Professores e alunos numa aula, médico e doentes num grupo terapêutico, clientes habituais num bar, crianças num infantário - todos eles constituem configurações relativamente compreensíveis (Elias, 2008: 143). 
Configuração e processo são conceitos de Elias que tornam as estruturas sociais e as estruturas da personalidade imbricadas uma nas outras. Devem ser encontrados em situações de interdependências entre as partes - sejam elas de ordem afetiva, econômica ou social -, numa relação atravessada pelo poder e pela busca do equilíbrio de forças. Assim, vemos que, a partir da ideia de configuração, os objetos da sociologia, da educação e da psicanálise não podem ser tomados em seus campos restritos, na medida em que fazer isso seria considerá-los em sua parcialidade. Essas disciplinas avançam ao considerá-lo em sua interdependência, situados em um processo de formação que deve ser visto sempre a longo prazo.

\section{Referências bibliográficas}

BLONDEL, Jacqueline (2001), “Encadeamento e regularidades nas 'ciências da cultura': Seguindo Friedrich Nietzsche, Max Weber, Norbert Elias", in A. Garrigou e B. Lacroix (orgs), Norbert Elias: A política e a história, São Paulo, Perspectiva, pp. 43-64.

CHARTIER, Roger (2001), "Formação social e economia psíquica: A sociedade de corte no processo civilizador", in N. Elias, A Sociedade de Corte, Rio de Janeiro, Jorge Zahar Editor, pp. 7-25.

COLLIOT-THÉLÈNE, Catherine (2001), "O conceito de racionalização: De Max Weber a Norbert Elias", in A. Garrigou e B. Lacroix (orgs), Norbert Elias: A política e a história, São Paulo, Perspectiva, , pp. 23-42.

DELMOTTE, Florence (2010), “Termes clés de la sociologie de Norbert Elias”, Vingtième Siècle: Revue d'histoire, 106, pp. 29-36 [Online], disponível em: http://www.cairn.info/revue-vingtieme-siecle-revue-d-histoire-2010-2-page-29.htm [consultado em 06 de maio de 2016].

DELZESCAUX, Sabine (2001), Norbert Elias: Une sociologie des processus, Paris, L'Harmattan.

ELIAS, Norbert (2010) [1990], "Le concept freudian de société et au-délà", in N. Elias, "Au-délà de Freud: sociologie, psychologie, psychanalyse”. Paris: Lá Découverte, pp. 131-186.

ELIAS, Norbert (2008) [1970], Introdução à Sociologia, Lisboa, Edições 70.

ELIAS, Norbert (2006), Escritos \& Ensaios: 1 - Estado, processo, opinião pública, Rio de Janeiro, Jorge Zahar Editor.

ELIAS, Norbert (2001) [1969], A Sociedade de Corte: Investigação sobre a sociologia da realeza e da aristocracia de corte, Rio de Janeiro, Jorge Zahar Editor.

ELIAS, Norbert (1994) [1987], A Sociedade dos Indivíduos, Rio de Janeiro, Jorge Zahar Editor.

ELIAS, Norbert (1993) [1939], O Processo Civilizador: vol. 2 - Formação do Estado e Civilização, Rio de Janeiro, Jorge Zahar Editor.

ELIAS, Norbert (1990) [1939], O Processo Civilizador: vol. 1 - Uma História dos Costumes, Rio de Janeiro, Jorge Zahar Editor.

JOLY, Marc (2010), "Dynamique de champ et 'événements': Le projet intellectuel de Norbert Elias (1930-1945)", Vingtième Siècle: Revue d'bistoire, 106, pp. 81-95, [Online], disponível em: http://www.cairn.info/revue-vingtieme-siecle-revue-d-histoire-2010-2-page-81.htm [consultado em 06 de maio 2016].

LAHIRE, Bernard (2010), "Freud, Elias et la Science de l'homme", in N. Elias, Au-delà de Freud: Sociologie, psychologie, psychanalyse, Paris, Éditions lá Découverte, pp. 187-213.

LEÃO, Andrea (2007), Norbert Elias e a Educação, Belo Horizonte, Editora Autêntica. 
Cruz, Rui Vieira - Ecos de um futuro passado : pós-memórias da nanotecnologia no cinema e videojogo. Configurações, vol. 19, 2017, pp. 48-71

\section{Ecos de um futuro passado' : pós-memórias da nanotecnologia no cinema e videojogos}

RUI VIEIRA CRUZ*

Universidade do Minho

\section{Resumo}

O nosso objetivo consiste em demonstrar que as indústrias culturais, enquanto criadoras de histórias, afirmam-se como autoridades de pós-memória que medeiam, através de artes visuais como o cinema e os videojogos, a construção social dos objetos nanotecnológicos. São diversos os filmes e videojogos representados no futuro em que o narrador/personagem principal apresenta ao espectador/jogador a sua memória traumática de eventos. Na ótica do espectador/jogador, estes acontecimentos ainda não decorreram, ecoando como um futuro no qual a sequência dos enredos é transmitida como passado. Estudamos as franquias de Terminator e Deus Ex tendo por base metodológica o programa de investigação científico (PIC) lakatosiano, sustentando que as pós-memórias prospetivas são movimentos transgeracionais de construção social em constante diálogo e em constante confronto, nos quais a destruição criativa tecnológica altera/inverte a sua configuração original e apresenta possíveis disrupções narrativas. Concluímos que o papel da nanotecnologia nas indústrias culturais se revela através de ícones e produtos que disciplinam a sua compreensão, refletindo um projeto tecno-político disruptivo, potenciador de uma nova Revolução Industrial.

Palavras-chave: nanotecnologia, cinema/videojogos, pós-memórias prospetivas; destruição criativa.

1 Uma ligação ao livro de banda desenhada The Uncanny X-Men (1981) Days of Future Past, traduzido para português (PT-PT) como Dias de um Futuro Passado (em PT-BR, Dias de um Futuro Esquecido), que aborda elementos de pós-memória.

*Centro Interdisciplinar de Ciências Sociais da Universidade do Minho (CICS.NOVA.UMinho) e Centro de Estudos em Comunicação e Sociedade da Universidade do Minho (CECS); E-mail: rmvcruz@ gmail.com 


\begin{abstract}
Days of Future Past ${ }^{2}$ : nanotechnology post-memories in cinema and gaming Our objective consists in explaining how cultural industries, as storytellers, act as post-memory authorities and mediate, through visual arts such as cinema and video games, on the social construction of nanotechnology objects. Many films and video games take place in a future where the narrator/main character presents the viewer/player to its traumatic memory of the events. In the viewer's/player's perspective, these events have not yet taken place, echoing like a future where the plots' sequence is transmitted as past. We studied the Terminator and Deus Ex franchises according to the Lakatosian scientific research program as a methodological basis. We argue that prospective post-memories are transgenerational movements of social construction, in constant dialogue and confrontation, in which technological creative destruction alters/inverts its original configuration and presents possible narrative disruptions. We conclude that nanotechnology's role in cultural industries reveals itself through icons and products that regulate its understanding, reflecting a disruptive techno-political project, thus enhancing a new Industrial Revolution.
\end{abstract}

Keywords: nanotechnology, cinema/video games, prospective post-memories; creative destruction.

\begin{abstract}
Résumé
Échos d'un futur antérieur : post-mémoires de la nanotechnologie au cinéma et aux jeux vidéo

Notre objectif est de démontrer que les industries culturelles, en tant que créatrices d'histoires, s'affirment comme des autorités de post-mémoire qui sont à la base, à travers d'arts visuels tels que le cinéma et les jeux vidéo, de la construction sociale des objets nanotechnologiques. Plusieurs films et jeux vidéo sont représentés dans un futur dans lequel le narrateur/personnage principal présente sa mémoire traumatique des événements au spectateur/joueur. Dans la perspective du spectateur/joueur, ces événements ne se sont pas encore produits, en faisant écho à un futur dans lequel la séquence des trames est transmise en tant que passé. Nous avons étudié les franchises Terminator et Deus Ex en ayant pour base méthodologique le programme de recherche scientifique lakatosien, soutenant que les post-mémoires prospectives sont des mouvements transgénérationnels de construction sociale en dialogue et confrontation constants, dans lesquels la destruction créatrice technologique modifie/inverse sa configuration originale et présente d'éventuelles perturbations narratives. Nous concluons que le rôle de la nanotechnologie dans les industries culturelles se révèle par des icônes et des produits qui régulent sa compréhension, en reflétant un projet techno-politique disruptif, levier d'une nouvelle révolution industrielle.
\end{abstract}

Mots-clés : nanotechnologie, cinéma/jeux vidéo, post-mémoires prospectives ; destruction créatrice. 
"Premonition... it's just remembering in the wrong direction" (Doctor Who, The Girl Who Died T9E5)

\section{Introdução}

Tecnologia e progresso têm formado uma aliança concetual e narrativa na qual Estado e indústrias atuam como autoridades de memória no incentivo à produção tecno-industrial. Os eixos da evolução tecnológica tornaram-se objeto de um debate, no qual a definição de nanotecnologia interseta a participação do campo científico, os avanços tecnológicos e os discursos políticos (Jones, $2007)^{3}$. Este ato, que combina o procedimento tecnocientífico e a participação política, criou concetualmente o elemento "nano" como um conjunto de ramos da ciência e tecnologia que trabalham com uma medida entre 1 a 100 nanómetros (nm) (Miller, Serrato, Represas-Cardenas e Kundahl, 2005). Por ser uma nova tecnologia assente numa medida de tamanho, as suas ligações com diversos campos científicos (física, química, engenharias...) e com setores de aplicação (energia, agricultura, robótica, militar) abriu espaço para a imaginação de pós-memórias e para a criação de diferentes cenários futuros.

Assim, visamos demonstrar três argumentos: i) as pós-memórias são construídas e constituem-se como espaços em constante diálogo e confronto; ii) o processo de destruição criativa de implementação nanotecnológica inverte a configuração original das pós-memórias; iii) as indústrias culturais alteram a concetualização tradicional das pós-memórias.

Enquadrados no programa de investigação científico (PIC) lakatosiano (Lakatos, 1967, 1989; Silva, 2009), visamos uma abordagem triangular entre o objeto técnico - nanotecnologia, o conceito operacional -, a pós-memória e os elementos que a manifestam, as indústrias culturais ${ }^{4}$. A partir da moldura de evolução tecnológica neoschumpeteriana ${ }^{5}$ e da concetualização de "destruição criativa", analisamos o modo como a nanotecnologia foi representada e como se compõe um quadro de autoridades de pós-memória em dois produtos das principais indústrias culturais de índole visual (cinema e videojogos): Terminator e Deus Ex. Sustentamos que a pós-memória e os traumas aliados às nanotecnologias suscitam elementos transgeracionais sobre os quais as indústrias culturais constroem identidades e representações da nanotecnologia. Ou seja, o cinema e os videojogos ${ }^{6}$ criam cenários traumáticos no futuro,

3 Em específico, a partir da sugestão do presidente americano, Bill Clinton, na década de 1990.

4 O programa de investigação científico lakatosiano é composto por núcleo e heurísticas. Se o núcleo permite manter a configuração original de uma teoria, a heurística possibilita a modificação e o cruzamento de teorias sem alterar o núcleo.

5 Schumpeter sistematizou a evolução da tecnologia e da inovação em diferentes ciclos padronizados.

6 Identificamos produtos culturais através da pesquisa da expressão nano (e derivados) em bases de dados comerciais - Amazon - e não-comerciais - IMDb e Metacritic. Dos 29 produtos validados, 
disciplinando sistemas de crenças, ações e representações no presente. Em cada um dos produtos culturais, procurámos a identificação de variáveis como o tempo cronológico, os eventos decorridos, a forma como a nanotecnologia é destacada na narrativa e o efeito traumático da sua aplicação.

\section{Das pós-memórias retrospetivas às pós-memórias prospetivas (mediadas): diálogos, confrontos e traumas tecnológicos}

Deparamo-nos com uma nova era da memória histórica na qual o passado se funde com o presente (Huyssen, 2003). A narrativa histórica ${ }^{7}$, que teve o "passado" como denominador comum e que outrora serviu para conectar a comunidade e a nação sob a égide de uma herança histórica, apresenta-se fragmentada (Hartog, 2003; Lorenz, 2010). Dessas ruínas, nasce uma história múltipla, regularmente contraditória e fraturada. Autobiografias, diários, testemunhos, documentários, docudrama (Valenzuela e Brandão, 2015), docuficções (Dondero e Bouko, 2015) e redes sociais online (Veltri e Atanasova, 2015) têm posto em causa a "memória de museu" e as suas reificações históricas hegemónicas.

Centrada na diferença geracional, a pós-memória distingue-se da memória

pela distância geracional e da história pela sua profunda conexão pessoal. A pós-memória é uma poderosa e muito particular forma de memória precisamente porque a sua conexão com o seu objeto ou fonte é mediada, não por meio da lembrança, mas através de um investimento imaginativo e criativo... A pós-memória caracteriza a experiência daqueles que cresceram dominados pelas narrativas que precederam o seu nascimento, e cujas próprias histórias são evacuadas/invisibilizadas pelas histórias da geração anterior moldada pelos eventos traumáticos que não podem ser percebidos ou recriados (Hirsch, 1997: 22) .

Na citação de Hirsch (idem, ibidem), denota-se uma distância geracional, uma divisão histórico-temporal entre emissores - possuidores de uma vivência em primeira instância - e recetores de conteúdos, uma geração que não experienciou esses eventos. Estes possuem apenas memórias mediadas, uma forma de conhecimento indireto, pelo que são forçados a recorrer à imaginação para vislumbrar os eventos. Os eventos traumáticos ocupam, contudo, um lugar de destaque no desenvolvimento desta geração, sendo regularmente dominados e

procurámos um filme e um videojogo que compusessem uma franquia com um mínimo de três entradas principais, excluindo spin-offs. Procedeu-se à seleção de uma saga cinematográfica e uma de videojogos: Terminator e Deus Ex.

7 Hartog (2003) define o regime de historicidade em dois pilares: em sentido estreito, como uma sociedade trata o seu passado; e em sentido lato, como os regimes de historicidade desenham a modalidade de consciência.

8 Itálicos nossos. 
constrangidos por essas mesmas ocorrências ${ }^{9}$. Argumentamos que a formulação de pós-memória de Hirsch (Hirsch, 2008; Hirsch e Spitzer, 2006, 2009) revela limitações concetuais: a distância intergeracional assenta numa abordagem geracional top-down, do indivíduo mais velho para o mais novo, similar aos storytellers (Gerbner, 2012), e não assume que o inverso é igualmente exequível. Propomos que a pós-memória se constitui como um sistema transgeracional em que é possível às gerações mais novas transmitir a ocorrência de eventos não experienciados pelas gerações mais velhas. Isto coloca os trabalhos tradicionais sobre pós-memórias numa vertente retrospetiva, ou seja, focam-se em eventos passados e re-imaginados pelos indivíduos. Argumentamos que a inovação tecnológica inverte esta tendência, projetando regularmente possibilidades na construção do futuro. Para isso, abordamos conceptualmente a ideia de "pós-memórias prospetivas" (Cohen e Gollwitzer, 2008), ou seja, de eventos que ainda não se realizaram, mas que se inserem na mente dos indivíduos como algo a realizar. A pós-memória prospetiva é o ato de "lembrar de lembrar" (Cohen e Gollwitzer, 2008), um processo cognitivo envolvido na formação e execução de intenções futuras (McFarland e Glisky, 2012). Consiste em projetar a memória (Tenenboim-Weinblatt, 2013) e resulta em ações tão simples como lembrar de fechar a tampa da pasta de dentes, ou mais complexas, como antecipar resultados do conflito entre a Rússia e a Ucrânia aquando a independência da Crimeia em 2014, ou configurar o sucesso em resgatar indivíduos raptados consoante o tempo decorrido. A pós-memória prospetiva assenta em experiências passadas, realizadas por terceiros, e sustenta-se em repetições que moldam o futuro e potenciam algo de inovador num presente imaginado. Este tipo de abordagem de pós-memória, diferenciada da convencional, ocorre já que outras formas de veiculação, assentes nas indústrias culturais e nas tecnologias de informação e comunicação (TIC) (por exemplo, redes sociais online), possuem a capacidade de transmitir conteúdos em registo textual, de imagem e vídeo e fundir diferentes produtores e recetores de conteúdos. Operam como agentes de mediação e propagação para elementos fora da rede (Centola, 2015) nos quais os ecrãs absorvem o choque, filtram e difundem os impactos do trauma (Hirsch, 2008), atuam como um escudo protetor que liga o passado, o presente (e o futuro). Operacionalizámos, por isso, o conceito de "pós-memória prospetiva mediada" (Tenenboim-Weinblatt, 2013), que assenta na experiência direta de eventos não-presenciados e que possibilita a antecipação resultados ou de formas de atuação.

O papel que os mediadores (por exemplo, media, cinema, literatura) desempenham nas construções e nas negociações sociais é o de servir como práticas para contabilizar e marcar o tempo. Contribuem para manter a narrativa e a

9 O enfoque original localizou-se na forma como as pós-memórias dominavam as vidas dos filhos dos sobreviventes do holocausto (Hirsch, 2008). 
memória sobre ela pela simulação de eventos futuros (Platt, Kamboj, Italiano, Rendell e Curran, 2016), organizar/ritualizar o tempo coletivo e dar pistas perante situações hipotéticas: se acontecer X, podemos atuar de forma Y. Por isso, pós-memórias não são uma posição de identidade. São elementos de poder simbólico e icónico sustentado pelo facto de diferentes gerações possuírem diferentes princípios semióticos. Elementos visuais e textuais ocupam posições diferenciadas na memória e procedem a contributos distintos (McFarland e Glisky, 2012). Por sua vez, as tecnologias e as suas técnicas de previsão incorporam um efeito diferenciador em relação às pós-memórias, visto dependerem destas formas de prospeção. Os ciclos tecnológicos de produção vão tornando, progressivamente, produtos inovadores em produtos obsoletos, em relíquias que ganham o seu espaço em museus ${ }^{10}$. O processador 4004 da Intel, de 1971, embora se constitua como um marco histórico da revolução das TIC, rapidamente $^{11}$ se tornou obsoleto, sendo substituído por modelos de maior capacidade. Esta aceleração tecnológica torna momentos historicamente significantes no desenvolvimento tecnológico em apenas momentos historicamente simbólicos (Martins, 2003). São transformadores, disruptivos, sem, no entanto, representarem um choque cultural imediato. Contudo, a utilização destes de forma regular e sistemática cria um "enxame tecnológico" na produção e no consumo. Esse é o seu contributo para a produção de choques culturais, sendo o mais recente (década de 1970) a revolução das Tecnologias de Informação e Comunicação (Garcia, 2011; Perez, 2007), enquanto a nanotecnologia apresenta potencial para se tornar a próxima revolução tecnológica, substituindo as TIC. Esta (r)evolução tecnológica diferencia-se, assim, de movimentos únicos, como golpes de Estado, revoluções políticas e conflitos bélicos, as tradicionais divisórias nas análises político-históricas que configuram um espaço "antes-evento" e "pós-evento". Argumentamos que o choque cultural da tecnologia se apresenta de uma outra forma: não é focado num único evento transformador, é transitivo.

É a partir desta configuração temporal linear - pré e pós-evento - que surge o interesse das análises sobre pós-memória na temática do trauma, com enfoque regular em transitividades e traumas políticos como, por exemplo, escravatura, holocausto, conflitos militares (Berberich, 2011; Hirsch, 1997; Matsumura, 2008), descartando os traumas tecnológicos. Ocorrências traumáticas nesta esfera são rapidamente interligadas com outros fenómenos de índole sociopolítica, subalternizando a técnica/tecnologia e o seu potencial. O teste aos limites dos sistemas de segurança culminou no desastre nuclear em

10 Museus de tecnologia, museus de videojogos, museus de ciência.

11 A lei de Moore, uma observação feita por Gordon Moore, cofundador da Intel, determina que, a cada 18 meses, é criado um novo processador com o dobro da capacidade e metade do tamanho. Após a criação do Intel 4004, em 1971, sucedeu-se o 8008, em 1972, e a consequente evolução para o 4040 e o 8080, em 1974. 
Chernobyl (Ucrânia), em 1986, e, mais recentemente, os problemas na central nuclear em Fukushima (Japão), em 2011, afetaram a aceitação popular sobre energia nuclear. As experiências com energia nuclear afetaram também as indústrias culturais: o filme Stalker (Tarkovsky, 1979) atuou como reação ao desastre de Chelyabinsk, em 1957, e como premonitório em relação a Chernobyl, de $1986^{12}$.

Portanto, conhecimento situado gera memórias situadas. E as pós-memórias ressentem-se disso. Nos desastres nucleares, temática relacionada com a discussão política e descaracterizada da sua componente técnica, as pós-memórias coletivas de europeus e japoneses na sua compreensão são distintas das de países não afetados, da mesma forma que judeus e nazis não possuem as mesmas pós-memórias coletivas referentes à 2a Guerra Mundial. Outros exemplos de traumas tecnológicos foram as falhas técnicas que provocaram as fissuras que levaram ao acidente na barragem de Bangqiao (China), em 1975, conduzindo à morte de mais de 150 mil pessoas e a mais de 10 milhões desalojados. O acidente químico de Bhopal (Índia), em 1984, gerado pelo desgaste das condutas de gás, comportou a morte de entre 3 a 16 mil indivíduos, afetando mais de 500 mil. Os apagões em Northeast (EUA), em 1965 (falha no sistema de distribuição da rede) e em 2003 (bug no software), deixaram mais de 30 e 55 milhões de norte-americanos sem energia elétrica, respetivamente, levando a motins e assaltos ${ }^{13}$.

Esta criptomnésia ${ }^{14}$ social, ou melhor criptomnésia sociotécnica, é regularmente fundamentada pelos estudos centrados nos impactos da tecnologia (Ball, 2010, Gordijn, 2005, Grinbaum, 2010, Laan, 2010). A tecnologia afeta comportamentos e dinâmicas sociais, mas a sua construção é amplamente configurada como um deus ex machina - como algo que, simplesmente, aparece na vida social. Esta limitação ignora, por exemplo, que a transição do sistema industrial fordista-keynesiano para as TIC fez emergir novas figuras, como os hackers. Imaginados como "piratas", foram-lhes atribuídas capacidades de alterar o posicionamento de mísseis ou invadir estabelecimentos bancários a partir de casa. Antagonicamente, tidos como libertadores, os hackers revelam novas formas de lutar contra um sistema opressivo e compõem figuras como as de cyberhackers e biohackers. A aceitação ou rejeição tecnológica (e das suas figuras) potencia um imaginário social e culmina na demonstração de que não

12 Personagens como Godzilla, lançado originalmente no Japão, em 1954, e zombies, como os recriados no filme The Night of the Living Dead, de 1968, compõem algumas das figuras nascidas dos riscos associados ao desenvolvimento tecnológico e aos perigos de contaminação nuclear resultante da execução de testes militares com energia atómica.

13 A energia elétrica, tida como garantida desde as "Guerras das Correntes", no final do século XIX, quando Nikola Tesla criou o sistema de distribuição de corrente alternada, alertou um país para os esforços diários necessários para a garantir.

$14 \mathrm{O}$ ato de experienciar uma memória como algo novo. 
há relações de poder e de domínio sem resistências (Foucault, 2001; Krips, 2010).

No entanto, a (pós)memória é falível. Os testemunhos exigem uma contínua desconstrução dos elementos criados pelos participantes e dos recetores externos. Exige também um trabalho de memória (Ricoeur, 1984, 1986) para ser regularmente lembrada. O léxico do imaginado entrou na realidade discursiva através destes trabalhos de memória, triangulando tecnologias, pós-memórias e indústrias culturais. Este sistema "torna o estranho familiar" (Gil, 2002). Referências culturais como o Big Brother (do livro 1984, de George Orwell) servem de exposição a modelos de vigilância, sistemas de autoridade e programas televisivos. Na nanotecnologia, a imagem da miniaturização destaca-se pela presença de minissubmarinos que atacam infeções e combatem vírus. Portanto, as pós-memórias são espaços construídos em constante diálogo e confronto. São recursos escassos, mas plurais, que competem umas com as outras. Simultaneamente multidirecionais (Rothberg, 2009) e competitivas, as pós-memórias não são somente história narrada ou oficial: são poesia, literatura, fotografia, cinema ou videojogos. As memórias coletivas estruturam-se, portanto, como “pós-memórias hibridas”. Existem perigos quando as pós-memórias são reificadas em formatos como as histórias de vida, os flashbacks, as narrativas mitificadas ou um cérebro central (Martins, 2006): os perigos da histórica única (Adichie, 2007) do ponto de vista do domínio hegemónico ou exclusivista. Ao selecionar apenas pedaços da memória (Orlando, 2016), corre-se o risco de tornar estática uma prática dinâmica. Desta ação disciplinadora, surgem pós-memórias coletivas que desempenham um papel fulcral no plano da política e sociedade:

As imagens da Guerra do Vietname limitam o apoio às atividades militares americanas; memórias do período nazi restringem a política externa e doméstica alemã; lembranças do período ditatorial moldam as atividades dos regimes de transição e de pós-transição, desde a Europa de Leste à América Latina; e Watergate tornou-se o ponto de referência perene para todos os subsequentes escândalos em Washington (Olick, 1999: 333).

\section{Evolução cíclica: pós-memórias e destruição criativa}

Schumpeter (2003: 81), um dos principais estudiosos no estabelecimento de ciclos económicos, desenvolveu o conceito de destruição criativa e definiu-o como uma mutação industrial que "incessantemente revoluciona a estrutura económica a partir de dentro, incessantemente destruindo o antigo, incessantemente criando um novo". Deste conflito entre o "novo" e o "velho" resulta 
uma vantagem competitiva que cria uma vaga de imitadores ${ }^{15}$ e somente aí, pelo resultado da competição, é gerada uma corrida de inovação que irá destruir as empresas, sistemas de produção ou tecnologias que não são capazes de a acompanhar: "este processo de destruição criativa gera a entrada de novos inovadores e a saída dos velhos inovadores” (Aghion e Howitt, 2006: 275). Esta força de destruição criativa torna o outrora novo em obsoleto, dando origem a novos processos, novas tecnologias, novas realidades e novas mundividências (Schumpeter, 1947; Shionoya, 2007).

$\mathrm{Na}$ teoria cíclica, o processo de evolução é padronizado, a sua direção não o é (Balabkins, 2003). É através desta metamorfose que a destruição criativa se alia às pós-memórias prospetivas. A destruição criativa pode “destruir" velhas tecnologias, mas não destrói as memórias que os indivíduos têm delas e os traumas que possam ter gerado. As gerações anteriores dominavam tecnologias que, entretanto, se tornaram obsoletas, enquanto as novas gerações, desligadas deste processo, incorporaram as novas tecnologias sem a assimilação das anteriores. Este trabalho de memória e de partilha suscita um diálogo transgeracional assente no trauma, mas numa dupla aceção do "risco": aventurar, de forma a suplantar o trauma; ou recear, rejeitando o "novo". Por isso, uma nova tecnologia pioneira, por exemplo, nanotecnologia, não se limita à criação de novas indústrias produtivas, mas também de sistemas políticos e culturais, económicos e sociais ${ }^{16}$. O sucesso num setor tecnológico molda a sua integração em outras áreas como as indústrias culturais e atrai a atenção para a consideração do que é uma inovação desejável:

O sucesso em qualquer sector inicialmente afeta a organização social ao elevar a posição do 'líder' bem-sucedido e por lhe conferir...uma base de poder social. Sucesso em qualquer sector influencia os valores sociais em geral, aquilo que chama atenção, o que está a ser considerado como bom ou desejável. E em todos estes sucessos em qualquer sector de atividade social eventualmente terá um efeito formativo ao longo de todos os sectores da vida social. (...) Desconectamos isto de um conjunto rígido de cadeias causais e devolvemos-lhe à vida, novamente. E nesta compreensão holística do desenvolvimento cultural, a economia também tem o seu espaço próprio (Schumpeter, 2002: 431) ${ }^{17 .}$

Tecnologias e pós-memórias necessitam de uma base social comum, em que a inovação resulta num processo que se estabelece entre diversos agentes: “A competição da (...) nova tecnologia (...) age, não apenas quando já existe,

16 Isto não significa que a tecnologia seja o prime-mover social (a infraestrutura no quadro da terminologia marxista). Demonstra que a tecnologia é afetada pelos sistemas sociais, políticos e económicos, mas que afeta tais sistemas. Alguns exemplos: o automóvel alterou o sistema de transportes; ii) a eletricidade mudou o sistema social; iii) a internet modificou a produção cultural; e estas invenções moldaram o sistema económico, social, político e cultural.

17 Itálico nosso. 
mas também quando é meramente uma ameaça sempre presente. Disciplina antes de atacar" (Schumpeter, 2003: 84-85)18. Este disciplinamento ocorre, sobretudo, de duas formas: canibalização (Kauffman e Techatassanasoontorn, 2012; Osarenkhoe, 2010) e Brand Value over Time (BVoT) (Wasserman, 2015).

O efeito de canibalização é uma estratégia assente no processo de destruição criativa (Herrmann, Sprott e Schlager, 2015; Peng, Agarwal, Hosanagar e Iyengar, 2014), quase sempre presente ${ }^{19}$ pela substituição regular de hardware e software (Marchand e Hennig-Thurau, 2013). Por sua vez, o BVoT sustenta uma ligação consistente entre criadores, produtos e consumidores (Holt, 2002; Wasserman, 2015). Os produtos tecnológicos substituem-se, mas mantêm uma coerência previsível (Motohashi, Lee, Sawng e Kim, 2012; Nagar, 2015). Esta capacidade de reprodução ${ }^{20}$ constante, na qual a escala temporal transforma o "novo" em "velho", configura o estado-da-arte tecnocientífico (Schmidt, 2008). Visto que as tecnologias e as (pós)memórias não existem num vácuo, imaginar a nanotecnologia a partir das pós-memórias mediadas cria um conjunto de pistas para a real aplicabilidade. É aqui que as indústrias culturais disciplinam e imaginam a aplicação das tecnologias e fomentam novas pós-memórias.

\section{Objeto artístico nas indústrias culturais: representações, unidade e efeito Diderot}

As representações sobre a arte não são estáticas e sofreram alterações, inicialmente delimitando espaços de fronteira entre alta arte, elitista, e baixa arte, popular (Bauman, 2007, 2010). Essas fronteiras apresentam-se atualmente mais esbatidas e integradas (Bauman, 2007). A fluidez da produção cultural promove o acesso a bens culturais através de diversos formatos (por exemplo, Internet, redes sociais online), a partilha e a promoção informações similares por diferentes indivíduos (Bauman, 2009, 2010). Porém, a forma como a sociedade industrial organizou a sua base tecnológica tende para um totalitarismo (Marcuse, 1977, 2002) não em termos políticos, mas na forma como os produtos fazem parte integrante da identidade dos indivíduos e dos grupos sociais: “as pessoas reconhecem-se nos seus produtos” (Marcuse, 2002: 11). As indústrias culturais que operam através da imagem (por exemplo, cinema, videojogos) promovem uma relação social entre indivíduos mediada pelas imagens, atuando como uma forma de fetichismo da mercadoria (Debord, 1995). É possível perceber as categorias de assimilação e as formas ideológicas de promoção de conteúdos. As indústrias culturais possuem a função de uniformização, de diluição dos fenómenos, um controlo fantasmagórico do desejo (Cruz, 2002;

18 Itálico nosso.

19 A título de exemplo, os cartuchos usados no sistema da NES (1985) não são compatíveis com os da tecnologia seguinte, a SNES (1990). Os cartuchos do modelo seguinte, N64 (1996), também não eram compatíveis com os anteriores.

20 A lei de Moore atua também como um princípio demonstrável da destruição criativa e das formas de canibalização comercial. 
Miranda, 2002), mas também uma função educativa e ilustrativa, servindo de mínimo cultural comum, que transmite uma formação ilustrativa de unidade, uma representação de uma realidade. O cinema assenta numa visualização passiva em que o indivíduo assiste ao filme (Zimmer, 2011), mas atua como ilusão, integrando-o nele, fazendo-o crer que faz parte dele (Allen, 1993). Por sua vez, os videojogos permitem interatividade com a narrativa e a utilização diferenciada de materiais nanotecnológicos por parte dos jogadores (Cruz, 2013). Esta ideia de unidade, o efeito Diderot ${ }^{21}$, molda o comportamento das indústrias culturais e assenta em duas premissas: i) os produtos consumidos têm em vista a identidade do consumidor; ii) e a introdução de um novo, mas atípico produto catalisa um processo de consumo em espiral: "Eu era o mestre absoluto das minhas velhas vestes. Eu tornei-me escravo das minhas novas" (Diderot, 2005: 2). Se, na primeira parte desta frase, está implícita a habituação numa forma quase alienante e reificante, na segunda, o objeto toma o controlo e fomenta uma transformação comportamental. A ação social passa a ser mediada pelos produtos (fetichismo da mercadoria), fundindo a pós-memória (enraizamento de uma narrativa) e a destruição criativa na incorporação nanotecnológica. O "novo" reflete o desconhecido, mas é através do fetichismo da mercadoria que “o novo" é transformado em algo reificável, expectável, conhecido e agregador, mediado pelas indústrias culturais. Não transforma somente o "novo" em "velho". Transforma a sua base: o processo.

As indústrias culturais disciplinam a inovação resultante da destruição criativa, em que novos meios aumentam o ritmo de adesão e os seus impactos (Martins, 2003). Veículos como a rádio, a banda desenhada, o cinema e a Internet demonstraram, junto dos seus públicos ${ }^{22}$, um conjunto de possibilidades imaginadas do potencial da tecnologia, contribuindo para a sua internalização/domesticação (Pereira, 2002) e para fomentar uma aceleração temporal (Hassan, 2010; Rosa, 2003; Violante, 2002) que resulta numa fusão entre passado-presente-futuro (Dawesar, 2013) e entre o físico e o virtual ${ }^{23}$. Na banda desenhada, as interpretações das relações entre judeus e nazis retratadas em MAUS, de Art Spieglman, apresentam uma analogia animal entre gatos e ratos e vislumbram a forma como um filho imaginou a vida dos pais num campo de concentração nazi (Hirsch, 1993). A Guerra Fria e os impactos da energia

21 Quando Diderot procedeu à aquisição de um novo manto, notou que nenhum dos antigos produtos que detinha estava em consonância com o seu novo produto. Como tal, procedeu à substituição das suas antigas posses, levando a um consumo em espiral de novos produtos que estivessem em sintonia com o seu novo manto.

22 A título de exemplo, a leitura radiofónica de War of the Worlds gerou uma onda de pânico nos Estados Unidos, em 1938; o combate público do Superman contra o Klu Klux Klan, numa série de 16 episódios intitulados "Clan of the Fiery Cross", transmitidos na rádio e na banda desenhada durante a década de 1940, gerou uma onda de consciencialização de crianças e adolescentes contra o KKK.

23 Um vídeo deixado numa plataforma de distribuição online (por exemplo, o Youtube) pode ser consultado anos após a sua produção (futuro), transmitindo uma ideia do seu criador no tempo presente, que, entretanto, se tornou passado. 
nuclear foram alvo de estudo da formação identitária da editora de banda desenhada Marvel Comics e do modo como esta editora promoveu estas temáticas junto de crianças e adolescentes (Genter, 2007). Também o cinema tem contribuído para a reflexão das pós-memórias traumáticas, incidindo em tópicos tão diversificados como as reclusas marroquinas (Orlando, 2016), os períodos de fome na Ucrânia na década de 1930 (Gurga, 2012, 2014), os contributos da União Soviética para a memória do Terceiro Reich (Berghahn, 2006), a reflexão intergeracional sobre familiares aliados ao regime nazi (Berberich, 2011), a sinofonia após a revolução cultural (Chen, 2015), os laços sociais na zona desmilitarizada coreana (Choe, 2013) e os impactos e reflexões sobre a bomba atómica no Japão (Matsumura, 2008).

Aliada ao trauma, está a figura do fantasma quase omnipresente que paira constantemente sobre a realidade. Um evento torna-se, assim, numa figura social que desempenha um papel numa tomada de decisão. Uma demonstração do peso fantasmagórico da pós-memória histórica ocorre na representação jurídica de Holodomor, na Ucrânia - uma tentativa de extermínio pela fome durante 1932-33 -, quando, em 2006, o governo local emitiu uma lei que estabeleceu que esquecer ou negar o que considerou um genocídio contra o povo ucraniano era passível de ação jurídica. Este genocídio foi regularmente lembrado pelo cinema ucraniano que desempenhou um "trabalho de memória" para não esquecer o evento/trauma (Gurga, 2014). As obras Prey (Crichton, 2006) e The Diamond Age (Stephenson, 1995) expandiram este efeito fantasmagórico da pós-memória para a esfera da nanotecnologia. Crichton (2006) aliou o fantasma ao invisível e secundarizou a definição científica de nanotecnologia para incidir sobre as suas aplicações, traumas e riscos. A temática centrada na ameaça à saúde e nas representações em torno da concetualização de Drexler (1990) de um cenário de gosma cinza no qual os nanorobots entrariam nas corrente sanguíneas e começariam um ciclo interminável de replicação constante serviu para estes autores abrirem espaço à fundamentação das suas narrativas. Na banda desenhada, Livewires (Warren e Mays, 2005) e The Authority (Ellis e Hitch, 1999) apresentam ao leitor um mundo repleto de possibilidades técnicas, mas também de traumas e conflitos ${ }^{24}$.De forma distinta, o filme e os estudos sobre El Laberinto del Fauno (Del Toro, 2006) relembraram o peso da herança histórica deixada pelo franquismo em Espanha, mas centrados na sua conclusão: a importância de esquecer e matar o passado (Miles, 2011). Esta destruição criativa de pós-memória - o esquecimento ativo do período ditatorial - não se configurou enquanto ato de alienação, mas em

24 As ciências sociais ancoraram a nanotecnologia a uma série de narrativas históricas e mitos, também alguns deles extraídos das indústrias culturais. De futuros utópicos (Roco, 2007; Smalley, 2007) a futuros distópicos (Gordijn, 2005), do mito do Golem (Grinbaum, 2010) às frankenfoods (Ball, 2010; Laan, 2010), da caixa de Pandora (Dupuy, 2010) ao socialismo científico marxista (Toumey, 2011), as narrativas assentes em (pós)memórias têm contribuído para as representações da produção nanotecnológica. 
trabalhos de memória de ativamente apagar uma ideologia, em não permitir que aquele passado traumático influencie o futuro (Gómez-Castellano, 2013). Trata-se de projetar um futuro pela construção do presente, sem a intervenção de um passado específico. Os discursos do que era - o passado - fundem-se com a execução real do presente e com as potencialidades possíveis no futuro.

Os espaços virtuais/imaginados comprimiram a narrativa na História. Deixamos de perceber a narrativa numa evolução linear de passado-presente-futuro para passarmos a ter indivíduos presentes em diversos espaços em diversos tempos - digital now (Dawesar, 2013). A ficção na literatura, cinema, séries televisivas e videojogos tem consistentemente avançado com cenários (oscilando entre possível, plausível e irrealista) que moldam e acostumam os seus recetores a novas vagas tecnológicas. A pós-memória não é somente o passado tornado presente. As memórias não são blocos de legos que se vão encaixando e acumulando em que o peso do passado determina o presente. Por isso, a pós-memória prospetiva (Kliegel e Martin, 2003) evita um efeito "ovo de colombo": perceber a solução após nos ser revelada. Ao invés, reforça a criação e reflexão de novos elementos narrativos, em diferentes formatos, apresentando diversos choques e incongruências.

\section{Nanotecnologia e traumas tecnológicos: dos diálogos e conflitos das pós-memórias, à destruição criativa e efeito Diderot em Terminator e Deus Ex}

Terminator e Deus Ex são duas franquias ${ }^{25}$ que demonstram como as indústrias culturais criam "pós-memórias prospetivas mediadas” da nanotecnologia. Ao centrar as suas narrativas no futuro, criam representações de eventos traumáticos - guerras, genocídios e conflitos sociais globais - que ainda não aconteceram. Este futuro imaginado apresenta-nos uma geração mais nova a demonstrar aos espectadores, a geração mais velha, a sua visão do trauma como se fosse o presente. A representação do conflito e do trauma assenta na nanotecnologia e ambos os produtos apresentam uma dicotomização acentuada: Terminator foca o binómio entre humanos e máquinas e Deus Ex entre bio-humanos e trans-humanos. No primeiro, a nanotecnologia é apresentada do lado das máquinas como uma característica que as torna superiores e como obstáculo que os humanos têm de superar. No segundo, a nanotecnologia é incorporada nos humanos e transmite uma ideia de evolução: separa o humano biologicamente determinado, o bio-humano, do trans-humano, alguém que

25 Terminator é composto por cinco filmes: i) The Terminator (1984); ii) Judgment Day (1991); iii) Rise of the Machines (2003); iv) Salvation (2009); v) Genisys (2015). Deus Ex é composto por quatro videojogos: i) Deus Ex (2000); ii) Deus Ex: Invisible Wars; iii) Deus Ex: Human Revolution; iv) Deus Ex: Mankind Divided. 
superou a sua condição biológica, mas é heteronomamente controlado pela tecnologia (Garcia, 2003).

Terminator é narrado do futuro para o passado/presente e apresenta três períodos temporais: i) 2018, a era em que as máquinas/inteligências artificiais entram em guerra declarada com os humanos; ii) 2029, em que as máquinas disputam as batalhas/eventos principais com os humanos; e iii) os períodos temporais em que cada filme decorre. Ancorado narrativamente no ano de 2029, os humanos lançam uma ofensiva global contra a inteligência artificial (IA) Skynet, resultando na vitória dos humanos no conflito contra as máquinas que se desenrolava desde 2018, o ano em que as máquinas lançam uma ação global de genocídio contra os humanos. São regularmente focados dois destinos de evolução tecnológica. No primeiro caso, a proximidade tecnológica do modelo T-800 com os humanos torna-o num objeto sapiente e senciente. O seu sacrifício pessoal serve como metanarrativa da aproximação da tecnologia com o que ainda é humano (Kline, 2009; Muri, 2003) e representa um ponto no qual a tecnologia foi criada por humanos com o objetivo de os servir. No segundo, os modelos seguintes, por exemplo, T-1000, T-X e T-3000, demonstram a perda da sua humanidade, uma transformação numa tecnologia que deixa de ser produzida por humanos e de os servir. Nesta nova direção de evolução, os humanos tornam-se desnecessários e as máquinas são capazes de processar os meios mais eficientes para cumprir os seus objetivos.

A imagem do humano obsoleto e objeto de extermínio presente na saga Terminator está fortemente imbricada na metáfora do holocausto: "a decisão de exterminar, não apenas um grupo enquanto tal, mas também todos os seres humanos classificados como pertencentes a esse grupo, até ao último" (Ribeiro, 2010: 10). O processo de reconfiguração substituiu os nazis pelas máquinas e fundiu os judeus na conceção de humanos. Contudo, há reformulações narrativas: os elementos obsoletos derrotam os inovadores, ou seja, os humanos derrotam as máquinas e um velho modelo T-800 contribui derrotar as tecnologias estado-da-arte, os modelos T-1000, Terminatrix e T-3000. O conflito militar e a política de extermínio geraram um efeito traumático fantasmagórico sempre presente, no qual os filmes configuram as ações do passado e do presente como causadoras do conflito de 2029 e as ações de pós-memória transmitidas para os públicos a partir da narração dos humanos ${ }^{26}$. Neste desenrolar, o testemunho e a memória são subordinados à reconstrução histórica e ao apuramento dos factos (Ribeiro, 2010). A narrativa segue um fluxo próprio no qual a ação de memória dos protagonistas serve apenas como enredo explicativo dos eventos maiores. A oscilação entre passado-presente-futuro representa a hibridez dos trabalhos de memória e apresenta, numa mesma narrativa, diversas versões das mesmas personagens. 
Por sua vez, Deus Ex apresenta ao jogador um futuro distópico no ano de 2052, colocando-o no controlo de um agente nano-aumentado com capacidade super-humanas, no qual os elementos de poder económico estão diretamente relacionados com as atribuições físicas. A humanidade foi atingida por um vírus cuja vacina não consegue ser produzida em quantidade suficiente para todos e é apenas distribuída pelos indivíduos vitais para o funcionamento societal. O nível de desigualdade social manifestado conduziu a motins à escala global entre dois grandes grupos: bio-humanos e nano-melhorados. Deus Ex Invisible Wars ocorre em 2072, 20 anos após Deus Ex, e apresenta ao jogador um mundo em conflito no qual quatro fações entraram em conflito: i) isolacionistas, que fortificaram as suas cidades e limitaram o acesso de refugiados; ii) fações religiosas, que lutam pelo fim da nanobiomodificação; iii) fações que se pretendem expandir globalmente e gerar uma raça somente de trans-humanos; e iv) uma fação que pretende um patamar de igualdade global e a criação de um mínimo de biomodificações comum a todos os (trans)humanos. O último dos três títulos, Deus Ex: Human Revolution, ocorre em 2027, e atua como prequela. $\mathrm{O}$ foco da narrativa nas vantagens/desvantagens do trans-humanismo, na dimensão bélica do conflito e nas desigualdades sociais da engenharia genética revela o nascimento dos acontecimentos traumáticos dos outros dois jogos. Entre personagens que pretendem ultrapassar a condição bio-humana através da nano(bio)tecnologia e aqueles que pretendem a evolução natural da espécie, o foco nos nanomelhoramentos como estado-da-arte, apenas acessível a um nicho minoritário em locais similares a supermercados genéticos (Garcia, 2006), despoletou um nível de desigualdade social difícil de controlar. A introdução da nanotecnologia neste leque serviu para criar um terceiro grupo (nano-melhorados) e veio demonstrar que os quadros de evolução económica, social e cultural não foram capazes de acompanhar a evolução tecnológica.

Uma crítica manifesta-se de forma latente em Terminator. A IA Skynet, resultado da ligação da tecnologia aos conflitos militares humanos, passa a encarar os humanos como um vírus que tentam erradicá-la. Nesta ótica, as máquinas lutam pela autopreservação e revelam-se como seres sapientes que, progressivamente, perdem a capacidade senciente de compactuar com os humanos, escalando o nível de violência, normalizando-a, numa ação similar à banalização do mal (Arendt, 2006). Dependem unicamente da lógica, operam a partir de um cérebro central (Hayles, 2006) e visam eliminar o problema que compete com o seu sentido evolutivo como sendo apenas mais uma tarefa a cumprir. Também em Deus Ex todas as fações lutam pela autopreservação das suas formas de vida, da sua evolução e das suas culturas dentro de um grande binómio: abraçar ou rejeitar a revolução nanotecnológica.

Em Terminator, a nanotecnologia é incorporada na robótica, e as máquinas, tecnologicamente mais fortes, competem ativamente com os obsoletos humanos. A missão das máquinas passa por se camuflarem como humanos 
e passarem despercebidas no meio destes: conferir uma ideia de unidade na sua diversidade. Em Deus Ex, a nanotecnologia incorpora-se nos humanos e fomenta o trans-humanismo, alterando a função social da nanotecnologia. Esta dicotomia entre bio-humano e trans-humano constata-se através da indumentária.

\section{Imagem 1 \\ Trans-humanos (indumentária)}

Os inovadores trans-humanos (representantes da revolução tecnológica) foram

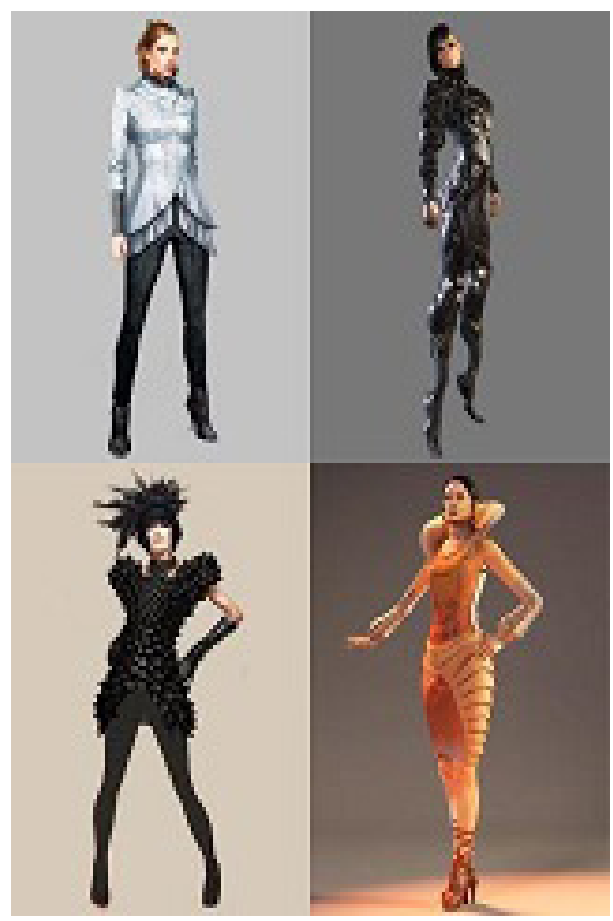
artisticamente incutidos de um espírito Renascentista encaixado no quadro estilizado cyberpunk (imagem 1)enquanto os bio-humanos são representados com jeans e $t$-shirt (imagem 2) algo mais similar aos códigos de vestuário atuais, reproduzindo uma visão estática da evolução e não uma revolução. O processo de destruição criativa e efeito Diderot adensa-se: no momento em que a humanidade subiu um degrau na evolução, a obrigação de ser constituída apenas por bio-humanos torna-se desnecessária.

Fonte: Square Enix.

No momento em que os trans-humanos abarcaram algo novo demonstraram a necessidade de alterar as suas vivências e incorporar novos bens (o vestuário e estilos de vida) que conferissem uma unidade à sua decisão. $\mathrm{O}$ objetivo da indumentária, nos trans-humanos, consiste em distinguir-se dos humanos, o que se diferencia de Terminator. Neste franchise cinematográfico, a necessidade da as máquinas de se assemelharem aos humanos para otimizar a 
infiltração militar conecta-se com a imagem do cyborg (Haraway, 1985; Shields, 2006) e a forma como aquelas se constituem como agentes híbridos (imagem 3$)^{27}$.

\section{Imagem 2 \\ Bio-humanos (indumentária)}

O objetivo das máquinas consiste em erradicar os humanos, mas o seu efeito de

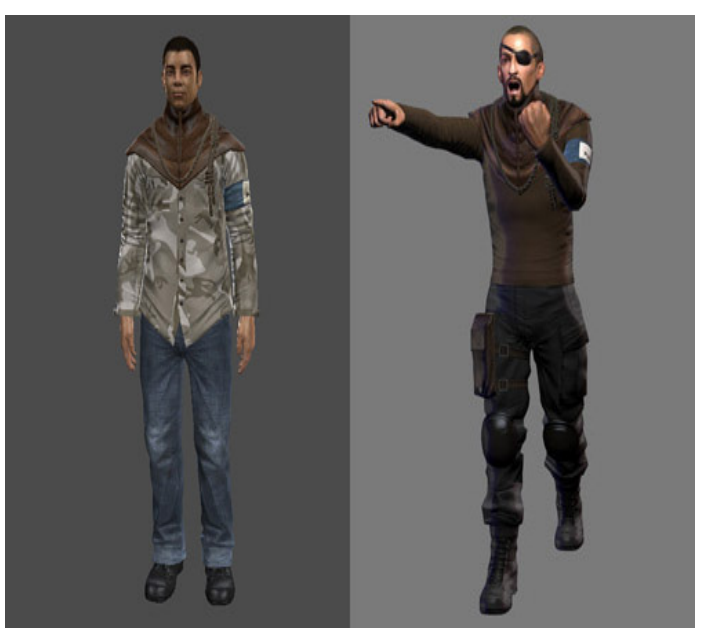
unidade distingue-se de Deus Ex, uma vez que a ideia de unidade reside na forma como as máquinas comunicam entre elas e não na forma como elas se assemelham aos humanos. Deus Ex e Terminator apresentam, por isso, duas formas distintas do processo de destruição criativa e do efeito Diderot, sem no entanto, alterarem as bases fundamentais dos conceitos.

Fonte: Square Enix.

Imagem 3

Diferentes Terminator e a sua semelhança Humano-Máquina

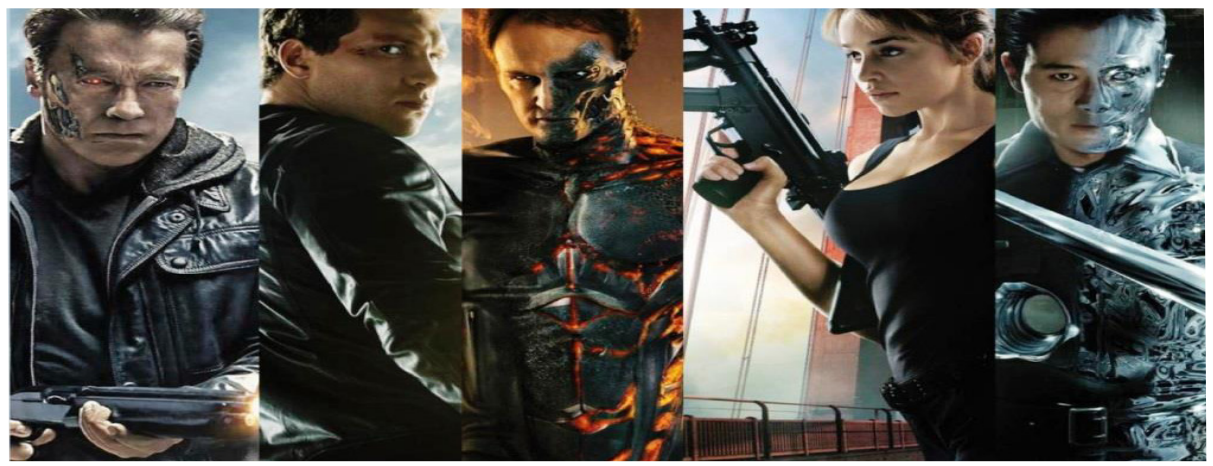

Fonte: Poster promocional da Paramount Pictures.

27 No entanto, não podemos deixar de destacar que a cada Terminator foi atribuído um elemento de género, centrado no binómio masculino-feminino. 
Um elemento diferenciador reside na distinção entre os humanos e as máquinas e na suscitação do binómio "Nós” e "Eles”, identidade e alteridade. Em Terminator, os humanos, por força das circunstâncias, unem-se para combater as máquinas, também elas unidas em torno da IA Skynet. A viagem no tempo foi um resultado do trauma do conflito bélico travado entre as duas fações. Em Deus Ex, esta conceção de viagem de tempo foi substituída pela ação do jogador, visto que ele pode escolher com que fação quer cooperar e que mundo quer vislumbrar no futuro. O conflito está sempre presente, não havendo uma dicotomia entre "bons" e "maus", apenas entre bio-humanos e trans-humanos. A humanidade apresenta-se, por isso, dividida.

\section{Notas finais}

As pós-memórias são narrativas tendencialmente mitificadas que ora discutem, ora compactuam com a história oficial. Ao centrarmos a análise nas pós-memórias prospetivas mediadas no cinema e nos videojogos, constatamos que ambas apresentam diversos trajetos evolutivos para a humanidade a partir da nanotecnologia. Tendo o futuro como pano de fundo, a franquia Terminator coloca os humanos em conflito aberto com as máquinas, controladas por uma inteligência artificial, e a saga Deus Ex contrapõe bio-humanos, que aguardam a evolução natural, a trans-humanos, responsáveis pelo seu próprio trajeto evolutivo. Esta ideia de superação do "natural” domina a narrativa para suscitar eventos traumáticos, as guerras de 2027 e 2052, em Deus Ex, e 2018-2029, em Terminator, difundindo a ideia dos humanos como agentes obsoletos, e culmina numa luta pela preservação das espécies. A ideia de extermínio e genocídio, regularmente presente nos estudos da pós-memória, manifesta-se no conflito entre humanos e máquinas, em Terminator, e entre as diversas fações sociopolíticas, em Deus Ex, em particular os bio-humanos e os trans-humanos.

A ideia de "humanos obsoletos" - como se estes fossem o alvo de um processo de destruição criativa - determina uma representação do percurso de evolução que a espécie tomou, fundamentado pelo efeito Diderot que compôs a noção de unidade na aparente pluralidade trans-humana. Esta ideia de unidade consiste numa diferenciação de status dos grupos sociais e resulta da fusão da incorporação da produção tecnológica com a indumentária utilizada. No momento que os bio-humanos transitam para o estado de trans-humanos, geram novos processos culturais. Cada inovação tecnológica introduzida comporta uma mudança nas dinâmicas comportamentais.

Ambas as indústrias culturais medeiam e suavizam a temática do trauma (extermínios, genocídios e guerras) através da ação dos ecrãs e da análise destas temáticas recorrendo a cenários fictícios. A nanotecnologia como composição do processo de destruição criativa atua como catalisador de um 
conjunto de evoluções a partir dos humanos. Conectada com a robótica em Terminator, configura-se como o traço distintivo das máquinas, atribuindo-lhes maior resistência, velocidade e capacidade adaptativa, embutidas num sistema de transmissão e comunicação. Em Deus Ex, a nanotecnologia é integrada nos trans-humanos, melhorando as suas capacidades de regeneração, de saúde e configura a jogabilidade dos três videojogos. O cruzamento da jogabilidade com a narrativa desempenha um papel diferenciado em Deus Ex, visto possibilitar ao jogador decidir a qual das diferentes fações pretende demonstrar apoio. Esta ação de imersão proporciona ao jogador a escolha do seu trajeto individual e uma forma específica de encarar o jogo. A jogabilidade, fenómeno não exequível no cinema, confere um aspeto diferencial e constitui-se como uma das mais-valias dos videojogos. Aliar a nanotecnologia à narrativa em Terminator e à jogabilidade em Deus Ex permite a ambas as franquias explorar e desenhar um futuro e recontá-lo no presente.

Entre as inúmeras possibilidades técnicas aliadas às novas e velhas formas de desigualdade social, a ação premonitória não assenta em adivinhar se tal irá ocorrer. Visa ilustrar o que é possível ou plausível e antecipar ocorrências, atuando como pós-memória prospetiva. Crer que a nanotecnologia é apenas tecnologia, é como julgar que um vaso Ming é apenas cerâmica.

\section{Referências bibliográficas}

ADICHIE, Chimamanda (2007), "The Danger of a Single Story" [Online], Disponível em: https://youtu.be/D9Ihs241zeg [consultado em: 3 fevereiro 2016].

AGHION, Philippe, HOWITT, Peter (2006), "Joseph Schumpeter Lecture Appropriate Growth Policy: A unifying framework", Journal of the European Economic Association, 4 (2/3), pp. 269-314.

ALLEN, Richard. (1993), "Representation, Illusion, and the Cinema”, Cinema Journal, 32 (2), pp. 21-48.

ARENDT, Hannah (2006), Eichmann in Jerusalem: A Report on the Banality of Evil, London: Penguin Classics.

BALABKINS, Nicholas W. (2003), "Adaptation Without Attribution? The Genesis of Schumpeter's Innovator" in J. Backhaus (ed.), Joseph Alois Schumpeter: Entrepreneurship, Style and Vision, New York, Springer, pp. 203-220.

BALL, Philip (2010), “Making Life: A Comment on 'Playing God in Frankenstein's Footsteps: Synthetic Biology and the Meaning of Life' by Henk van den Belt" (2009), Nanoethics, 4, pp. 129-132.

BAUMAN, Zygmunt (2007), Consuming Life, Cambridge: Polity Press.

BAUMAN, Zygmunt (2009), Does Ethics have a Chance in a World of Consumers?, Cambridge: Harvard University Press.

BAUMAN, Zygmunt (2010), Liquid Times: Living in an Age of Uncertainty, Cambridge: Polity Press.

BERBERICH, Christine (2011), "We Shall Be Punished': Positionality and Postmemory in Rachel Seiffert's The Dark Room and Uwe Timm's In My Brother's Shadow”, Holocaust Studies, 17 (2-3), pp. 261-282. 
BERGHAHN, Daniela (2006), "Post-1990 screen memories: How East and West German cinema remembers the third Reich and the Holocaust", German Life and Letters, 59 (2), pp. 294-308.

CENTOLA, Damon (2015), “The Social Origins of Networks and Diffusion”, American Journal of Sociology, 120 (5), pp. 1295-1338.

CHEN, Lingchei Letty (2015), "When does 'diaspora' end and 'Sinophone' begin?”, Postcolonial Studies, 18 (1), pp. 52-66.

CHOE, Youngmin (2013), "Postmemory DMZ in South Korean Cinema, 1999-2003”, Journal of Korean Studies, 18 (2), pp. 315-336.

COHEN, Anna-Lisa, GOLLWITZER, Peter M. (2008), "The Cost of Remembering to Remember: Cognitive load and the implementation intentions influence ongoing task performance", In M. Kliegel (Ed.), Prospective Memory: Cognitive, neuroscience, developmental, and applied perspectives, New York, Erlbaum, pp. 367-390.

CRICHTON, Michael (2006), Prey: A novel, London: Harper Collins Publishers.

CRUZ, Maria Teresa (2002), “Técnica e Afecção”, in J. B. de Miranda e M. T. Cruz (orgs.), Ligações_Links_Liaisons, Lisboa, Tropismos, pp. 31-46.

CRUZ, Rui Vieira (2013), “Nanotecnologia e Videojogos: Contestar a narrativa do Norte a partir das Epistemologias do Sul”, Configurações, 12, pp. 199-218.

DAWESAR, Abha (2013), "Life in the 'Digital Now"” [Online], TEDTalk, disponível: https:// www.ted.com/talks/abha_dawesar_life_in_the_digital_now?language=en [consultado em: 3 fevereiro 2016].

DEBORD, Guy (1995), The Society of the Spectacle, New York: Zone Books.

DEL TORO, Guillermo (2006), El Laberinto del Fauno, Esperanto Films.

DIDEROT, Denis (2005), Regrets Sur ma Vieille Robe de Chambre, Ebooks Lib.

DONDERO, Maria Giulia, BOUKO, Catherine (2015), "My Friend is a WWI Soldier: A Semiopragmatic Approach to Docufictions on Social Networks", Punctum. International Journal of Semiotics, 1 (1), pp. 94-107.

DREXLER, K. Eric (1990), Engines of Creation: The coming era of nanotechnology, New York: Anchor Books.

DUPUY, Jean-Pierre (2010), “The Narratology of Lay Ethics”, Nanoethics, 4, pp. 153-170.

ELLIS, Warren, HITCH, Bryan (1999), The Authority, LaJolla: Wildstorm/DC Comics.

FOUCAULT, Michel (2001), Power: The essential works of Michel Foucault, vol. 3, New York, New Press.

GARCIA, José Luís (2003), "Sobre as Origens da Crítica da Tecnologia na Teoria Social”, in H. Martins e J. L. Garcia (orgs.), Dilemas da Civilização Tecnológica, Lisboa: Imprensa de Ciências Sociais, pp. 91-138.

GARCIA, José Luís (2006), "Rumo à Criação de Desenhada de Seres Humanos? Notas sobre Justiça Distributiva e Intervenção Genética”, Configurações, 2, pp. 89-101.

GARCIA, José Luís (2011), “Internet, New Forms of Power and Democracy", Revista Internacional de Sociología, 69 (3), pp. 747-781.

GENTER, Robert (2007), “'With Great Power Comes Great Responsibility': Cold War culture and the birth of Marvel Comics", Journal of Popular Culture, 40 (6), pp. 953-978.

GERBNER, George (2012), “The stories we tell ourselves”, Journal of International Communication, 18 (2), pp. 237-244.

GIL, José (2002), “Ligação de Inconscientes”, In J. B. de Miranda e M. T. Cruz (orgs.), Ligações_ Links_Liaisons, Lisboa: Tropismos, pp. 21-30.

GÓMEZ-CASTELLANO, Irene (2013), "Lullabies and Postmemory: Hearing the ghosts of Spanish history in Guillermo del Toro's Pan's Labyrinth (El laberinto del fauno, 2006)”, Journal of Spanish Cultural Studies, 14 (1), pp. 1-18. 
GORDIJN, Bert (2005), "Nanoethics: From utopian dreams and apocalyptic nightmares towards a more", Science and Engineering Ethics, 11 (4), pp. 521-533.

GRINBAUM, Alexei (2010), “The nanotechnological golem”, Nanoethics, 4 (3), pp. 191-198.

GURGA, J. J. (2012). Echoes of the Past: Ukrainian poetic cinema and the experimental ethnographic mode, Phd thesis, London: University College London.

GURGA, J. J. (2014), “Remembering (in) Ukrainian Cinema of the 1960s: Rolan Serhiienko's White Clouds (1968)", Studies in Russian and Sovietic Cinema, 5 (3), pp. 353-370.

HARAWAY, Donna (1985), “Manifesto for Cyborgs: Science, technology, and socialist-feminism in the 1980s", Socialist Review, 80, pp. 65-108.

HARTOG, François (2003), Régimes d'Historicité: Présentisme et expérience du temps, Paris: Le Seuil.

HASSAN, Robert (2010), "Social Acceleration and the Network Effect: A defence of social 'science fiction' and network determinism”, British Journal of Sociology, 61 (2), pp. 356-374.

HAYLES, N. Katherine (2006), "Unfinished Work: From cyborg to cognisphere", Theory, Culture \& Society, 23 (7-8), pp. 159-166.

HERRMANN, Andreas, SPROTT, David, SCHLAGER, Tobias (2015), "What Drives Leapfrogging? Empirical assessment of consumer determinants of leapfrogging”, Total Quality Management \& Business Excellence, 28 (3-4), pp. 266-281.

HIRSCH, Marianne (1993), "Family Pictures: Maus, Mourning, and Post-Memory”, Discourse, 15 (2), pp. 3-29.

HIRSCH, Marianne (1997), Family Frames: Photography, narrative, and postmemory, Cambridge: Harvard University Press.

HIRSCH, Marianne (2008), “The Generation of Postmemory”, Poetics Today, 29 (1), pp. 103-128.

HIRSCH, Marianne, SPITZER, Leo (2006), “What'S Wrong With This Picture?”, Journal of Modern Jewish Studies, 5 (2), pp. 229-252.

HIRSCH, Marianne, \& SPITZER, Leo (2009), "Incongruous images: Before, during, and after the Holocaust", History and Theory, 48, pp. 9-25.

HOLT, Douglas B. (2002), "Why Do Brands Cause Trouble? A Dialectical Theory of Consumer Culture and Branding”, Journal of Consumer Research, 29 (1), pp. 70-90.

HUYSSEN, Andreas (2003), Present Pasts: Urban palimpsests and the politics of memory, Stanford: Stanford University Press.

JONES, Richard Anthony Lewis (2007), Soft Machines: Nanotechnology and life, New York: Oxford University Press.

KAUFFMAN, Robert J., Techatassanasoontorn, Angsana A. (2012), “Guest Editors” Introduction: Methods innovations for the empirical study of technology adoption and diffusion”, Information Technology and Management, 13 (3), pp. 113-114.

KLIEGEL, Matthias, MARTIN, Mike (2003), "Prospective Memory Research: Why is it relevant?”, International Journal of Psychology, 38 (4), pp. 193-194.

KLINE, Ronald (2009), “Where are the Cyborgs in Cybernetics?”, Social Studies of Science, 39 (3), pp. 331-362.

KRIPS, Henry (2010), “The Politics of the Gaze Foucault, Lacan and Žižek”, Culture Unbound: Journal of Current Cultural Research, 2, pp. 91-102.

LAAN, J. M. Van Der (2010), "Frankenstein as Science Fiction and Fact”, Bulletin of Science, Technology \& Society, 30 (4), pp. 298-304.

LAKATOS, Imre (1967), "Problems in the Philosophy of Mathematics", in Proceeding of the International Colloquium in the Philosophy of Science, Amsterdam: North-Holland Publishing Company, pp. 82-96. 
LAKATOS, Imre (1989), The Methodology of Scientific Research Programmes, New York: Cambridge University Press.

LORENZ, Chris (2010), "Unstuck in Time, or: The sudden presence of the past", in K. Tilmans, F. Van Vree e J. Winter (Eds.), Performing the Past Memory, History, and Identity in Modern Europe, Amsterdam: Amsterdam University Press, pp. 67-105.

MARCHAND, André, HENNIG-THURAU, Thorsten (2013), "Value Creation in the Video Game Industry: Industry economics, consumer benefits, and research opportunities", Journal of Interactive Marketing, 27 (3), pp. 141-157.

MARCUSE, Herbert (1977), The Aesthetic Dimension: Toward a Critique of Marxist Aesthetics, Boston: Beacon Press.

MARCUSE, Herbert (2002), One-Dimensional Man, London: Routledge.

MARTINS, Hermínio (2003), “Aceleração, Progresso e Experimentum Humanum”, in H. Martins e J. L. Garcia (orgs.), Dilemas da Civilização Tecnológica, Lisboa, Imprensa de Ciências Sociais, pp. 19-78.

MARTINS, Hermínio (2006), "Paths to the Post-Human: A very short guide for the perplexed", Configurações, 2, pp. 29-56.

MATSUMURA, Janice (2008), “The "All-Knowing” Japanese State? New scholarship on medicine, science, technology, and industrial relations", Minerva, 46 (1), pp. 77-86.

MCFARLAND, Craig, GLISKY, Elizabeth (2012), "Implementation Intentions and Imagery: Individual and combined effects on prospective memory among young adults", Memory \& Cognition, 40 (1), pp. 62-69.

MILES, Robert J. (2011), “Reclaiming Revelation: Pan's Labyrinth and The Spirit of the Beehive”, Quarterly Review of Film and Video, 28 (3), pp. 195-203.

MILLER, John C., SERRATO, Ruben M., REPRESAS-CARDENAS, José Miguel, KUNDAHL, Griffith (2005), The Handbook of Nanotechnology: Business, policy, and intellectual property law, New Jersey: Wiley Publishing.

MIRANDA, José Augusto Bragança de (2002), "Para Uma Crítica das Ligações Técnicas”, in J. A. B. de Miranda e M. T. Cruz (orgs.), Ligações_Links_Liaisons, Lisboa: Tropismos, pp. 259-278.

MOTOHASHI, Kazuyuki, LEE, Deog-Ro, SAWNG, Yeong-Wha, KIM, Seung-Ho (2012), "Innovative Converged Service and its Adoption, Use and Diffusion: A holistic approach to diffusion of innovations, combining adoption-diffusion and use-diffusion paradigms", Journal of Business Economics and Management, 13 (2), pp. 308-333.

MURI, Allison (2003), "Of Shit and the Soul: Tropes of cybernetic disembodiment in contemporary culture”, Body \& Society, 9 (3), pp. 73-92.

NAGAR, Komal (2015), "Consumers' Evaluation of Ad-Brand Congruity in Comparative Advertising”, Journal of International Consumer Marketing, 27 (3), pp. 253-276.

OLICK, Jeffrey K. (1999), "Collective Memory: The two cultures", Sociological Theory, 17 (3), pp. 333-348.

ORLANDO, Valérie K. (2016), “Women, Madness, Myth and Flm: Exploring Moroccan psychological trauma and postmemory in Pegase (Mohamed Mouftakir, 2010)", The Journal of North African Studies, 21 (1), pp. 90-107.

OSARENKHOE, Aihie (2010), "A Study of Inter-firm Dynamics between Competition and Cooperation: A coopetition strategy", Journal of Database Marketing \& Customer Strategy Management, 17 (3-4), pp. 201-221.

PENG, Jing, AGARWAL, Ashish, HOSANAGAR, Kartik, IYENGAR, Raghuram (2014), "Towards Effective Information Diffusion on Social Media Platforms: An analysis of dyadic network relationship", Thirty Fifth International Conference on Information Systems, Auckland, pp. 1-45. 
PEREIRA, Fernando José (2002), “Ligações Livres: Da construção fantasiosa à realidade doméstica”, in J. B. de Miranda e M. T. Cruz (orgs.), Ligações_Links_Liaisons, Lisboa: Tropismos, pp. 119-132.

PEREZ, Carlota (2007), "Great Surges of Development and Alternative Forms of Globalization”, Working Papers in Technology Governance and Economic Dynamics, 15, pp. 1-32.

PLATT, Bradley, KAMBOJ, Sunjeev K., ITALIANO, Tommaso, RENDELL, Peter G., CURRAN, H. Valerie (2016), "Prospective Memory Impairments in Heavy Social Drinkers are Partially Overcome by Future Event Simulation”, Psychopharmacology, 233, pp. 499-506.

RIBEIRO, António Sousa (2010), "Memória, Identidade e Representação: Os limites da teoria e a construção de testemunho", Revista Crítica de Ciências Sociais, 88, pp. 8-21.

RICOEUR, P. (1984). Time and Narrative. The American Historical Review, vol. I, Chicago: University of Chicago Press.

RICOEUR, Paul (1986), Fallible Man, New York: Fordham University Press.

ROCO, Mihail C. (2007), “Convergence and Integration”, in L. E. Foster (ed.), Nanotechnology: Science, Innovation and Opportunity, New Jersey, Prentice Hall, pp. 225-232.

ROSA, Hartmut (2003), "Social Acceleration: Ethical and political consequences of a desynchronized high-speed society”, Constellations, 10 (1), pp. 3-33.

ROTHBERG, Michael (2009), "Introduction: Theorizing Multidirectional Memory in a Transnational Age", in Multidirectional Memory: Remembering the Holocaust in the Age of Decolonization, Stanford: Stanford University Press, pp 1-29.

RUTTAN, Vernon W. (2010), "Usher and Schumpeter on Invention, Innovation, and Technological Change”, The Quarterly Journal of Economics, 73 (4), pp. 596-606.

SCHMIDT, Jan Cornelius (2008), "Normativity and Innovation: An approach to concepts of innovation from the perspective of philosophy of technology", Georgia Tech - Ivan Allen College Working Papers Series, 31, pp. 1-9.

SCHUMPETER, Joseph A. (1947), "The Creative Response in Economic History”, The Journal of Economic History, 7 (2), pp. 149-159.

SCHUMPETER, Joseph A. (2002), “New Translations: Theorie der wirtschaftlichen Entwicklung”, American Journal of Economics and Sociology, 61 (2), pp. 405-437.

SCHUMPETER, Joseph A. (2003), Capitalism, Socialism and Democracy, London: Routledge.

SHIELDS, Rob (2006), "Flanerie for Cyborgs", Theory, Culture \& Society, 23 (7-8), pp. 209-220.

SHIONOYA, Yuichi (2004), "Schumpeter's Preface to the Fourth German Edition of The Theory of Economic Development”, Journal of Evolutionary Economics, 14, pp. 131-142.

SHIONOYA, Yuichi (2007), Schumpeter and the Ideia of Social Science, Cambridge: Cambridge University Press.

SILVA, Sandra Tavares (2009), "On Evolutionary Technological Change and Economic Growth: Lakatos as a starting point for appraisal”, Journal of Evolutionary Economics, 19, pp. 111-135.

SMALLEY, Richard (2007), "Nanotechnology and Our Energy Challenge”, in L. E. Foster (Ed.), Nanotechnology: Science, innovation and opportunity, New Jersey, Prentice Hall, pp. 13-18.

STEPHENSON, Neal (1995), The Diamond Age, New York: Bantam Spectra.

SWEDBERG, Richard (2002), "The Economic Sociology of Capitalism: Weber and Schumpeter”, Journal of Classical Sociology, 2, pp. 227-255.

TARKOVSKY, Andrei (1979), Stalker, URSS: Mosfilm.

TENENBOIM-WEINBLATT, Keren (2013), "Bridging Collective Memories and Public Agendas: Toward a theory of mediated prospective memory", Communication Theory, 23 (2), pp. 91-111.

TOUMEY, Chris (2011), "Seven Religious Reactions to Nanotechnology”, NanoEthics, 5 (3), pp. 251-267. 
VALENZUELA, Sebastián, BRANDÃO, Angela S. (2015), “Historical Dramas, Current Political Choices: Analyzing partisan selective exposure with a docudrama", Mass Communication and Society, 18 (4), pp. 449-470.

VELTRI, Giuseppe A., ATANASOVA, Dimitrinka (2015), “Climate Change on Twitter: Content, media ecology and information sharing behaviour", Public Understanding of Science, (November online first), pp. 1-17.

VIOLANTE, Giovanni L. (2002), “Technological Acceleration, Skill Transferability, and the Rise in Residual Inequality”, The Quarterly Journal of Economics, 117 (1), pp. 297-338.

WARREN, Adam, MAYS, Rick (2005), Livewires, New York: Marvel Comics.

WASSERMAN, Brooke (2015), Valuation of Intangible Assets: Should brand equity be accounted for on the balance sheet?, Honors Scholar Theses, Storrs: University of Connecticut.

ZIMMER, Catherine (2011), “Surveillance Cinema: Narrative between technology and politics”, Surveillance \& Society, 8 (4), pp. 427-440. 
Marques, Ana Paula; Falleiros lalê - Metamorfoses na Política, Valores Empresariais e Governação em Saúde em Portugal. Configurações, vol. 19, 2017, pp. 72-88

\title{
Metamorfoses na Política, Valores Empresariais e Governação em Saúde em Portugal
}

\author{
ANA PAULA MARQUES* \\ Professora Associada, com Agregação, da Universidade do Minho \\ IALÊ FALLEIROS**1 \\ Professora e pesquisadora do Laboratório do Trabalho e da Educação Profissional da \\ Escola Politécnica de Saúde Joaquim Venâncio (EPSJV/Fiocruz)
}

\section{Resumo}

$\mathrm{O}$ artigo avalia o impacto das atuais estratégias empresariais na governação em saúde a partir de dois principais relatórios de enquadramento das políticas públicas, nomeadamente O Futuro da Saúde em Portugal (APAH/ APDH, 2007) e Um Futuro para a Saúde: Todos temos um papel a desempenhar (Crisp, 2014), confrontando-os com visões institucionais obtidas através de entrevistas aprofundadas a informantes privilegiados. Com base no projeto de mundialização da saúde ancorada na perspetiva neoliberal de Terceira Via, pretende-se analisar as mudanças programadas nas relações sociais de trabalho e do cuidado à saúde da população portuguesa. Os resultados evidenciam que as reformas projetadas para o futuro da saúde em Portugal já estão em curso há pelo menos uma década, conformando um processo de privatização e empresarialização do setor da saúde.

Palavras-chave: Portugal; Políticas de Saúde; Neoliberalismo, Privatização; Profissionais de saúde.

1 Estágio Pós-Doutoral em Portugal em 2014/2015, financiado pelo Programa de Pós-doutorado no Exterior da Coordenação de Aperfeiçoamento de Pessoal de Nível Superior (CAPES).

*Investigadora do Centro Interdisciplinar de Ciências Sociais (CICS.NOVA/ CICS-UMinho). E-mail: amarques@ics.uminho.pt

** Pesquisadora do Grupo de Estudos e Documentação sobre o Empresariamento da Saúde (GPDES IESC/UFRJ).E-mail: ialefalleiros@gmail.com 


\begin{abstract}
Metamorphoses in politics, entrepreneurial values and health governance in Portugal The article evaluates the impact of current business strategies on health governance from two main policy reports, namely "The Future of Health in Portugal" (APAH / APDH, 2007) and "A Future for Health - We all have a role to play" (Crisp, 2014), confronting them with institutional visions gathered through in-depth interviews with privileged informants. Based on the globalisation of health's strategy anchored in the neoliberal perspective of the Third Way, it is intended to analyse the scheduled changes in social relations of work and health care of the Portuguese population. Our main findings show that the reforms planned for the future of health in Portugal have been underway for at least a decade, forming a process of privatisation and entrepreneurship in the health sector.
\end{abstract}

Keywords: Portugal; Health policies; Neoliberalism; Privatisation; Health professionals.

\title{
Résumé
}

Métamorphoses dans la politique, les valeurs d'entreprise et la gouvernance de la santé au Portugal

Cet article évalue l'impact des stratégies d'entreprise actuelles en matière de gouvernance de la santé à partir de deux des principaux rapports d'encadrement des politiques publiques, notamment "L'avenir de la santé au Portugal » (APAH / APDH, 2007) et " Un avenir pour la santé - nous avons tous un rôle à jouer »(Crisp, 2014), les confrontant à des idées institutionnelles acquises grâce à des entretiens approfondis avec des informateurs clés. Sur la base de la stratégie de mondialisation de la santé, ancrée dans une perspective néo-libérale de la troisième voie, notre but est d'analyser les changements prévus dans les rapports sociaux du travail et des soins de santé de la population portugaise. Les résultats montrent que les réformes prévues pour l'avenir des soins de santé au Portugal sont déjà en cours depuis au moins une décennie, en conformant un processus de privatisation et de corporatisation du secteur de la santé.

Mots-clés : Portugal ; Politiques de santé ; Néo-libéralisme ; Privatisation ; Professionnels de la santé.

\section{Introdução}

A literatura académica recente indica que, em Portugal, o Serviço Nacional de Saúde (SNS), criado em 1979, sofreu mudanças ao longo das diferentes conjunturas político-económicas, mantendo-se, no fim da primeira década do século XXI, como "um sistema público, financiado por impostos, que funciona como seguro público, universal e obrigatório”, ainda que o Estado permaneça como "prestador de serviços de saúde e proprietário de uma parcela significativa do sistema” (Silva, 2012: 123).

Esse cenário é corroborado por outro estudo que aprofunda a compreensão sobre as metamorfoses na sociedade portuguesa e suas relações com 
a saúde (Correia, 2012). Neste estudo, afirma-se que as estratégias de difusão da cultura empresarial na área da saúde incidiram fortemente sobre as novas técnicas de administração, imprimindo nova racionalidade à gestão dos serviços públicos de saúde, mormente sobre os gastos com o consumo e os recursos humanos, por via da individualização das relações laborais. A capacidade de este setor ser "eficiente e apto a jogar com as regras do mercado" intensifica-se no quadro da política mais recente do Estado Português, que coincide com a intervenção financeira da Troika ${ }^{2}$, a partir de 2011. Fica "em aberto e na completa indefinição como os cuidados se prestam, por quem e sob que condições”, ao mesmo tempo que se promove "um contexto de concorrência entre o setor público e o setor privado" (Correia, 2012: 87).

A privatização dos serviços de saúde faz parte de um processo mais vasto de ressimbolização do espaço social de trabalho (Marques, 2009). Este apresenta-se indissociável das transformações dos modelos empresariais e de governação que corporizam a "cultura do novo capitalismo" (Sennett, 2007) na mesma linha dos argumentos que sustentam o "novo espírito do capitalismo" (Boltanski e Chiapello, 1999). São vários os argumentos nesse sentido, designadamente, o domínio da lógica do "curto prazo" no retorno do investimento financeiro por parte das empresas constituídas por acionistas (Sennett, 2007); a progressiva destruição de trabalho vivo (postos de trabalho e/ou profissões diversas) pela parametrização e imaterialização do mesmo em sistemas integrados de informação e gestão (Castells, 2003); e a crise da eficácia e eficiência dos modelos de governação de índole burocrático-racionalizadora, potenciando o “emagrecimento" das estruturas organizacionais com externalização de parte da produção de bens/serviços (Boyer, 1986).

Ora, as transformações nos contextos e práticas do exercício profissional da maior parte dos grupos profissionais (desde médicos a enfermeiros, incluindo profissionais associados à área da saúde) parecem estar relacionadas com a generalização de princípios de mercado e de um discurso gestionário e controlador explícito na lógica de resultados, qualidade e avaliação (Marques, 2014; Bezes e Dumazière, 2011; Macedo, 2002). Igualmente, as recomposições dos mercados (trans)nacionais, que caracterizam estes profissionais da área da saúde, podem ser compreendidas como resultantes de estratégias de fechamento social/ desprofissionalização e dos paradoxos emergentes das "novas direções” do profissionalismo (Evetts, 2012, 2010; Kulmann, 2012).

Neste artigo, pretende-se contribuir para o aprofundamento do conhecimento sobre a agenda política empresarial para o setor da saúde. A reflexão é apresentada em três secções, além da introdução e das notas finais. Na primeira

2 A 6 de abril de 2011, Portugal fez um pedido de assistência financeira à Comissão Europeia para garantir condições de financiamento ao país e ao seu sistema financeiro. Resultou daqui um memorando de entendimento entre o Banco Central Europeu (BCE), a Comissão Europeia e o Fundo Monetário Internacional (FMI). 
secção, situamos teoricamente o conceito de mundialização da saúde ancorado nos pilares do projeto designado como neoliberal de Terceira Via. Na segunda secção, apresenta-se uma discussão sobre as transformações nos referenciais das profissões na atualidade. $\mathrm{Na}$ terceira secção, apresenta-se a agenda empresarial para a saúde em Portugal a partir da análise de documentos selecionados e entrevistas em profundidade produzidas para este estudo.

\section{0 neoliberalismo de Terceira Via e a mundialização da saúde}

Desde o Consenso de Washington (1989) que o neoliberalismo vem sofrendo modificações. A partir do tratamento a ele conferido pelo programa da Terceira Via, o neoliberalismo passou a incidir sobre as relações sociais de trabalho, para além da lista de recomendações económicas voltadas para o aumento de produtividade, lucratividade das empresas e negócios privados. A atualização promovida pela autoproclamada social-democracia reformada logrou a coesão social necessária em favor do projeto capitalista para o século XXI, com recurso à desregulamentação laboral e ao enfraquecimento dos direitos profissionais conquistados/ concedidos pelo Estado de Bem-Estar (Neves, 2010).

$\mathrm{Na}$ arena de disputa de projetos societários, na segunda metade da década de noventa do século XX, o capitalismo "de face humana" deu vantagem aos projetos antagónicos, por meio de um programa definido a partir de quatro pilares: 1) o despontar de uma ordem social pós-tradicional com o fim da polarização ideológica e geopolítica característica da Guerra Fria e o desenvolvimento de uma globalização intensificadora; 2) o fortalecimento de um novo Estado democrático; 3) o florescimento de uma sociedade civil ativa; 4) e o ressurgimento do individualismo como valor moral radical (Giddens, 2001). Em linhas gerais, de acordo com esta perspetiva, estaríamos a viver um novo momento histórico em que as tradições são postas em cheque por uma cultura cosmopolita que, por sua vez, forja um novo individualismo e um estilo de vida cujas escolhas políticas passam a ser motivadas não por visões do mundo constituídas a partir de experiências de classe social, mas por critérios de eficiência, pragmatismo e inovação. Esta autonomia individual seria constituinte do aumento da reflexividade social, orientadora de escolhas baseadas na informação e no conhecimento disponíveis, em detrimento de ideologias. Graças à reflexividade social, as solidariedades desgastadas pela velha ordem seriam recuperadas, fundando uma cidadania ativa, na qual os indivíduos assumiriam novas responsabilidades a partir dos seus interesses e valores pessoais. O novo Estado democrático, nesse projeto, teria como premissa a abertura dos canais de participação de cidadãos ativos nas decisões políticas e nas ações antes restritas ao próprio Estado (Neves, 2010).

A Terceira Via supõe, tal como a doutrina (neo)liberal, que a superação da crise geral está na reforma do Estado e na sua desresponsabilização pela 
execução direta das políticas sociais. Entretanto, não defende somente a privatização e a passagem dessa responsabilidade para o mercado, mas, sobretudo, a sua transferência para as organizações da sociedade civil, por meio da criação do conceito de "público não-estatal" ou "terceiro setor" (Falleiros, Pronko e Oliveira, 2010).

O ideário neoliberal de Terceira Via tem-se difundindo nas diferentes áreas do conhecimento por meio de autores de feições teóricas diversas, que atuam na formulação de documentos produzidos por organismos financeiros internacionais, tais como, por exemplo, o Relatório sobre o Desenvolvimento Mundial de 1997, intitulado O Estado num Mundo em Transformação (Banco Mundial, 1997). O amplo programa de reformas políticas daí resultante visa reordenar a estrutura e o funcionamento dos sistemas de saúde, designado "mundialização da saúde". Esta corresponde ao avanço das forças de mercado sobre as atividades e os serviços públicos, à proliferação de valores e ideais empresariais sobre as atividades/serviços, ao exercício profissional orientado para a eficiência e ao comportamento dos clientes ou população-alvo. A base material fornecida pelas novas tecnologias de informação e comunicação, somadas à automação e à robótica, conflui para o desenvolvimento de uma cultura organizacional nos serviços de saúde baseada no modelo empresarial de gestão e de controlo do trabalho. Em Portugal, este movimento de "mundialização da saúde" assume relevância a partir dos primeiros anos do século XXI pela difusão da racionalidade empresarial sobre as atividades e os serviços públicos, sofrendo um avanço significativo a partir de 2011 por meio da ampliação da privatização desses serviços. Neste contexto, o ideário neoliberal de Terceira Via também tem expressão no pensamento político da saúde e é coincidente com as reformas no SNS, as mudanças nas relações laborais e nos contextos profissionais de saúde.

\section{Gestão, individualização e "erosão" da autonomia dos profissionais de saúde}

Assumir a confiança, a discricionariedade e a competência historicamente reivindicadas para se ser um profissional implica reposicionar o debate sobre as "margens de autonomia" que o mesmo possui nos diversos contextos organizacionais ${ }^{3}$. Ser "profissional" significava deter autoridade da ciência, apoio do Estado e confiança pública. Atualmente, importa analisar as reconfigurações

\footnotetext{
3 Neste domínio específico, são relevantes as transformações ao nível da formação académica superior que se confronta com uma multiplicidade de titulações em áreas afins. Estas conduzem quer a uma oferta diversificada de profissões certificadas ligadas aos serviços de saúde, quer à maior pressão de "monopolização" do mercado de trabalho perante o excesso de oferta de títulos em determinadas áreas (por exemplo, farmácia, nutrição, radiologia, fisioterapia, análises clínicas).
} 
dos grupos profissionais em relação aos diversos aspetos da sociedade contemporânea e aos debates teóricos de fundo sobre a mundialização da saúde.

São várias as controvérsias e tensões que indiciam discussões relevantes na relação entre Estado, trabalho e profissões. Estas tendem a situar-se numa linha de pensamento orientada ou para uma perspetiva anglo-saxónica ou francófona (Svensson e Evetts, 2010; Dubar e Tripier, 1998) ${ }^{4}$. Recentemente, são, ainda, convocados contributos que visam integrar neste debate as transformações decorrentes dos modelos organizacionais e de gestão pela adoção de pressupostos de mercado e de cariz privado nas políticas de reconfiguração do setor público na saúde. Em concreto, estas transformações caracterizam-se, em grande medida, pelo SNS implicar a passagem de uma parte significativa dos hospitais públicos, primeiro transformados em Sociedades Anónimas (SA) e, logo depois, em Entidades Públicas Empresariais $(\mathrm{EPE})^{5}$, dando corpo à tendência de empresarialização da rede de cuidados de saúde hospitalares (incluindo a privatização, a pressão para a qualidade e a externalização de serviços) ${ }^{6}$. Mais recentemente, no ideário político-gestionário neoliberal, encontram-se também serviços e estabelecimentos de prestação de saúde (agrupamentos de centros de saúde e unidades locais de saúde) que integram as redes de cuidados de saúde primários e continuados.

É nesta conjuntura que se compreende mudanças no setor da saúde português como "a separação entre financiamento e prestação dos cuidados", "a criação de um mercado interno regulado pelo Estado, garantindo competição entre prestadores públicos e entre prestadores públicos e privados”, as "alterações do sistema remuneratório dos médicos, afastando-os do regime de funcionário público (salários) e aproximando-o de profissionais liberais (honorários, diversificação salários)" e “a valorização dos cuidados de saúde privados ou concessionados” como resposta às listas de espera (Silva, 2012: 123). Associadas às reestruturações organizacionais e aos modelos de governação, as restrições orçamentais, acompanhadas quer de políticas de subfinanciamento de serviços diversos até então sob tutela do Estado, quer de cortes nas transferências dos orçamentos públicos para o SNS, explicam a menor capacidade de endogeneização destes profissionais no mercado interno de trabalho. O desemprego afigura-se como inevitável para muitos deles, bem como a tendência para

\footnotetext{
4 Para efeitos de economia de texto, não iremos problematizar distinções analíticas em torno da profissão, da ocupação e dos grupos profissionais. Assumimos como ponto de partida que os profissionais que detêm um certificado formal de nível superior e que se encontram associados a atividades relacionadas com o conhecimento.

5 A aproximação entre o funcionamento dos serviços públicos de saúde e o direito privado materializou-se na Lei n, 27/2002, de 8 de novembro, que criou o estatuto jurídico de "hospital EPE" (Entidade Pública Empresarial) e definiu o funcionamento do setor público com base nas regras concorrenciais de mercado.

6 Macedo $(2006$, 2002) destaca a supramacia das análises que valorizam uma vertente de aplicação voltada para a gestão hospitalar. Importa realçar, a este propósito, que já existiam indícios da referida tendência na legislação que regulamenta os hospitais ( $\$ 6$ do Decreto-lei n. ${ }^{\circ} 48357$, de 27 de abril de 1968).
} 
a precarização das condições salariais e contratuais. Nestas circunstâncias, a "fuga" dos profissionais tem explicado a sua maior mobilidade internacional (Amaral e Marques, 2014), provocando dificuldades na gestão dos recursos humanos afetos ao SNS (em hospitais, e sobretudo, em centros de saúde) ${ }^{7}$. Por sua vez, são apontadas tendências de recomposição de determinados grupos profissionais à luz da incorporação do que se designa "tecnologias da reforma" (Santiago e Carvalho, 2012), que se reportam à submissão destes profissionais aos princípios de gestão e produtividade, tal como aconteceu noutros países, em especial, no Reino Unido. A este nível, o setor da saúde, porque constituído maioritariamente por uma força de trabalho altamente formalizada e detentora de conhecimento, constitui uma "arena" interessante para explorar as consequências ao nível das (novas) formas de regulação estatal e suas práticas de governação na mobilização do discurso do profissionalismo na atualidade.

\section{A agenda empresarial para a saúde em Portugal e as novas prerrogativas profissionais}

Nesta secção, pretende-se compreender melhor o ideário empresarial incorporado na saúde portuguesa, por meio da análise dos principais relatórios de enquadramento das políticas públicas. Estes são: O Futuro da Saúde em Portugal (APAH/ APDH, 2007) e Um Futuro para a Saúde: Todos temos um papel a desempenhar (Crisp, 2014). De forma complementar, cruzaremos esta informação com a análise de conteúdo das entrevistas em profundidade realizadas a informantes privilegiados, nomeadamente, à presidente da Associação Portuguesa para o Desenvolvimento Hospitalar e Professora da Escola Nacional de Saúde Pública da Universidade de Lisboa, o diretor do Programa Inovar em Saúde, da Fundação Calouste Gulbenkian, e a vogal da Comissão Diretiva do mestrado em Gestão de Unidades de Saúde da Escola de Economia e Gestão da Universidade do Minho. A análise privilegiará o confronto entre os pilares do projeto de "mundialização da saúde" e as posições e perceções assumidas por um conjunto de intelectuais orgânicos individuais e coletivos (instituições).

\subsection{Do ideário empresarial na saúde portuguesa}

O livro O Futuro da Saúde em Portugal (APAH/ APDH, 2007) é um compêndio de 24 depoimentos produzidos por intelectuais reconhecidos no campo da saúde portuguesa, entre os quais se incluem dois ex-ministros da saúde e dois ex-diretores nacionais de saúde. Mais de metade ocupou funções de Estado no âmbito da saúde, da educação ou da ciência e tecnologia, um terço desempenhou

7 A este propósito, José Manuel Silva, Bastonário da Ordem dos Médicos, declarou em entrevista ao Expresso (24.02.2016) que, em Portugal, não há falta de médicos, mas "um problema de contratação para o Serviço Nacional de Saúde, ou de não contratação ou de dificuldade na contratação". 
funções públicas junto da Organização Mundial de Saúde, três exerceram cargos no grupo farmacêutico multinacional Merck Sharp \& Dohme e um era representante das Misericórdias.

A intenção da coletânea foi a de juntar depoimentos de várias figuras públicas sobre o futuro da saúde em Portugal, tendo em vista a "responsabilização de todos e de cada um nas escolhas que forem feitas e na definição do futuro" (APAH/ APDH, 2007: 10). Em princípio, pode imaginar-se um mosaico que se vai formando ao longo da leitura de cada um dos textos, sua abordagem, metodologia e narrativas próprias, revelando, pouco a pouco, o desenho do futuro da saúde em Portugal. Contudo, pretende-se, aqui, observá-lo como uma peça política, articuladora de um projeto coeso para orientar a reforma do sistema de saúde no país.

A totalidade dos textos afirma que, apesar do sucesso do SNS e das melhorias significativas nos índices de saúde da população portuguesa ao longo de sua existência, é necessário ajustá-lo aos novos tempos. O novo momento é caracterizado por alterações demográficas, envelhecimento da população, aumento exponencial dos problemas de saúde mental, aumento das doenças relacionadas com os estilos de vida e em que os doentes passam a atuar como consumidores (idem: 135). A principal estratégia do sistema de saúde do futuro deverá ser, nesse sentido, a prevenção de patologias crónicas, com o duplo objetivo de aumentar a qualidade de vida e reduzir gastos em saúde, de acordo com o encontro anual de Davos de 2005, Governors of the World Economic Forum for Health Care, e o relatório da OCDE de junho de 2006, a partir dos quais se afirma que os "gastos com a Saúde continuam a aumentar e, se as tendências perdurarem, os governos terão de aumentar os impostos, cortar as despesas em outras áreas ou aumentar as contribuições dos cidadãos” (idem: 123).

Reitera-se que se trata de uma mudança de paradigma, ou uma nova ordem pós-tradicional, cuja transição "se desloca de modelos assentes na prestação de cuidados em situações agudas para outros voltados para uma visão mais global do sistema" (idem: 221). Pode ler-se, ainda que uma única vez, que o neoliberalismo corresponde a uma regressão civilizacional. Não obstante, o discurso tende para definições mais restritas ao âmbito da saúde. Uma globalização intensificadora, primeiro pilar do neoliberalismo de Terceira Via, é identificada em afirmações como a de que "a globalização não é uma moda nem, muito menos, um álibi para contermos as fronteiras da nossa intervenção”, cujas expressões aparecem representadas por meio do "acesso quase ilimitado à informação", bem como do "livre-trânsito de profissionais no espaço europeu” e das "exigências sanitárias de uma crescente população de imigrantes" (idem: 101).

É possível ler-se em vários trechos a definição de SNS como uma articulação entre o mesmo e as restantes entidades privadas e sociais que com ele se articulam (idem: 176). Adverte-se, a este propósito, que, por um lado, 
se "a estruturação dos sistemas de Saúde e os cuidados ou as prestações que propiciam são reconhecidos como bens de interesse público", por outro, "a discussão sobre os objetivos e a natureza e dimensão da intervenção do Estado no sector, quer no domínio da prestação, quer no domínio do financiamento" é menos consensual (idem: 221). Neste sentido, o SNS é caracterizado como a "joia da coroa da nossa democracia”, enquanto o princípio da gratuidade geral é considerado "funesto", já que "apenas favorece os mais ricos”. Nesta linha de pensamento, defende-se a "modificação da forma de orçamentação, com a criação (...) de um imposto consignado à Saúde de acordo com a capacidade económica de cada um. (idem: 189-192).

A construção do segundo pilar do neoliberalismo de Terceira Via, um novo Estado democrático, expressa-se no pressuposto de que os recursos são escassos e que "o País gasta demasiado em Saúde”, ainda que esteja “abaixo da média europeia”. Assim, a solução passaria pela abertura do Estado às parcerias nacionais e internacionais na área, procurando "dar as melhores soluções a um custo otimizado, quer para o doente, quer para os parceiros". Ainda, nas "parcerias em Saúde, o Estado deve assumir-se como frágil, como pedinte, como devedor" (idem: 91-92).

Todos parecem concordar que o cenário estaria marcado pelo fim das polarizações entre Estado e mercado e pela aceitação de que é necessário ampliar o investimento público no mercado da saúde, dado que este gera empregos e movimenta a economia do país. O papel desse novo Estado seria o de promover os novos mercados da saúde, o empreendedorismo público e a indústria de bem-estar; ou, noutros termos, fortalecer a cadeia de valor na saúde para produzir melhores resultados (idem: 39-44). O documento governamental Pacto de Cooperação para a Solidariedade Social: 1997-2000, é apresentado por mais de um autor como um documento-chave ao articular a iniciativa pública e privada e ao contribuir para "[e]voluir no estatuto dos serviços de Saúde, de forma a permitir uma gestão mais flexível dos recursos humanos, materiais, tecnológicos e financeiros" (idem: 56).

A mudança organizacional proposta para as instituições estatais de saúde passa, por conseguinte, pela redefinição dos papéis de financiador, pagador e prestador - do Estado, dos utentes e do setor privado. Procurando qualificar esta discussão, afirma-se a necessidade de definição da fronteira entre os setores público e privado, promovendo a individualização e a profissionalização de cada um deles, cabendo ao Estado o incentivo ao setor privado para que recupere as infraestruturas de saúde e a concessão às entidades privadas da gestão de unidades hospitalares e outras (idem: 146-149). Pressupõe-se um Estado neutro, capaz de "dar um fio condutor à gestão equilibrada de todas as forças e tensões que a importância de um sistema de Saúde permite desenvolver”, auxiliado, por sua vez, por um sistema de informação e gestão intermédia no combate ao desperdício (idem: 173). 
A exaltação de uma sociedade civil ativa, terceiro pilar do neoliberalismo de Terceira Via, apresenta-se fortemente no conceito de "governação da saúde", definido como uma administração pública de qualidade, animada por empreendedores públicos qualificados, capaz de promover a excelência nas contribuições do setor privado na saúde (idem: 47). Afirma-se que o futuro pressupõe "promover esta postura dialogante com o Governo, o Parlamento, os partidos políticos, as associações de doentes, as organizações dos outros profissionais de Saúde", bem como "com todas as instituições com responsabilidade no domínio do medicamento e da política de Saúde" (idem: 85). A nova dinâmica social implica reforçar a esfera pública não estatal ou a interface público-privada na área da saúde, em que o risco é assumido pelo Estado e a lucratividade é garantida às empresas, reforçando o caráter da mundialização da saúde.

A dinamização de investimentos rentáveis na saúde é a tónica da discussão, a par com a noção de que a produtividade do país deverá sustentar-se numa força de trabalho ativa e, certamente, saudável. O chamado "setor saúde" é considerado sinónimo de riqueza ao criar empregos e gerar oportunidades também no domínio dos consumos de equipamentos e material clínico, pelo que deve passar de importador a exportador, e, finalmente, atuar em projetos turísticos junto de "pessoas com elevados recursos económicos e cuja idade pressupõe necessidades em saúde cuja satisfação deve ser assegurada" (idem: 175). Reforçando a ótica da mundialização da saúde, os centros de excelência ganham centralidade na agregação de valor às empresas.

A implementação da reforma da saúde na ótica apresentada depende, em grande medida, das estratégias de convencimento implementadas e do grau de coesão social alcançado em torno do projeto empresarial para a saúde. De facto, graças ao individualismo como valor moral radical, quarto pilar do neoliberalismo de Terceira Via, a perspetiva da proteção social é transmutada em atuação estatal sobre os "estilos de vida". A promoção de estilos de vida saudáveis e a atuação sobre doenças associáveis a causas do tipo socio-comportamental tornam-se, nesse sentido, elementos de adesão ao projeto em curso, por meio da mobilização da "sociedade portuguesa para a participação em ações de desenvolvimento da qualidade de vida e de assistência na doença a todos os cidadãos", com o "desenvolvimento do voluntariado, como expressão da mais demonstrativa qualidade da condição humana face ao sofrimento" (idem: 185).

Este projeto tem vindo a apresentar reconfigurações significativas na organização do trabalho e relações laborais na área da saúde. A reforma na administração pública assume como características: “adesão voluntária de profissionais e utilizadores, trabalho em equipa multiprofissional, obrigatoriedade de sistema de informação, regime remuneratório sensível ao desempenho, regime de incentivos, contratualização e avaliação" (idem: 139). Tal proposta abarca uma redução do número de profissionais da saúde, em especial 
de médicos, como funcionários do Estado (idem: 150). Nos termos de um dos autores, "há que pôr os médicos (únicos que conhecem os problemas em concreto e os concretos doentes que sofrem) perante as suas responsabilidades económicas” (idem: 205).

\subsection{Atualizações do ideário empresarial quanto ao futuro da saúde em Portugal}

O relatório do Programa Inovar em Saúde, da Fundação Calouste Gulbenkian, intitulado Um Futuro para a Saúde: Todos temos um papel a desempenhar (Crisp, 2014), elaborado sete anos após O Futuro da Saúde em Portugal, apresenta propostas ainda mais concretas na direção apontada no documento anterior. Entre os membros da Comissão Gulbenkian, dos grupos de trabalho e do conselho consultivo, seis são comuns em relação à publicação de 2007.

O documento de 2014 apresenta como tema central a noção de que o futuro da saúde depende do desempenho de todos na construção do novo pacto na área - "os cidadãos, os profissionais da saúde, os professores, os empresários, as autarquias, os governos” (Crisp, 2014: 3). O apelo à noção de um novo pacto na saúde remete para a crise económica e para as consequências que teve junto dos trabalhadores portugueses, com destaque para os profissionais de saúde: "A maioria da população tem sofrido uma redução no seu nível de vida e os funcionários públicos, incluindo os profissionais de saúde do SNS, tiveram uma redução no seu vencimento e viram baixar o valor das reformas que terão no futuro" (idem: 4). Tomando como ponto de partida a definição de que o corte de gastos em saúde é incontornável, apresenta uma proposta de reorientação do modelo de cuidados de saúde no país de modo a reduzir a incidência e a duração das doenças crónicas e, concomitantemente, os custos do sistema. Cabe a "todos" zelar pela meta de redução de $25 \%$ dos custos dos organismos públicos associados à saúde.

Traduzida em recomendações, a proposta traz elementos que podem ser associados à ideia de um novo Estado democrático. A palavra "Estado", contudo, não aparece no documento. As palavras "governo", "governamental" e mesmo "público" aparecem como correlatos do termo ausente, indicando uma reorientação das funções do Estado, que se torna parceiro de "todos" no gestão do novo modelo de cuidados e promoção da saúde, que se apresenta como centrado já não no hospital e na doença, mas nos cuidados domiciliários e na saúde. Nesta parceria, cabem à esfera pública a manutenção de um fundo com recursos para essa transição; o fomento da melhoria contínua da qualidade desses cuidados por meio da acreditação, do registo e da divulgação de boas práticas; e a colaboração com a investigação e a indústria através da criação de centros nacionais para o desenvolvimento de novas práticas, tecnologias e serviços.

Afirma-se que Portugal deve tirar vantagem dos progressos da ciência e tecnologia através da colaboração eficaz entre o SNS, a comunidade científica 
e a indústria da saúde. Na mesma linha, propõe-se o acordo público-privado como enquadramento para contratação de serviços privados pelo SNS, salvaguardando o interesse público e trazendo novos recursos e potenciais inovações ao sistema de saúde. A mudança da infraestrutura em saúde, desenvolvendo processos de contratualização e contratação, abrindo os serviços de saúde a novos métodos e formas de prestação seria uma das três estratégias centrais para a sustentabilidade do sistema (as outras duas são a prevenção e a redução do tempo de enfermidade e a aplicação eficaz da evidência científica). Tais afirmações exprimem uma visão do que seja o "País" em relação à distribuição das vantagens para toda a sociedade. Supõe, nesse sentido, uma neutralidade do Estado e uma imparcialidade das opções políticas que engendra, que lhe garantiria capacidade de salvaguarda do interesse público a despeito da participação dos interesses privados na produção dos serviços e ações de saúde.

A noção de sociedade civil ativa também dá suporte à proposta, segundo a qual um Conselho Nacional de Saúde deve ser constituído como uma instância "politicamente independente". Com a participação dos cidadãos e de todos os setores da sociedade, teria a missão de tutelar o pacto para a saúde e funcionar como consultor para as políticas que se associam a essa visão. "Todos” deviam estar representados nos órgãos de gestão das instituições em saúde e as autarquias deveriam incluir a saúde e as organizações de saúde nas suas parcerias locais de assistência social e de apoio ao trabalho e ao planeamento intersetoriais. Mais, “todos” (autarquias, organizações de saúde, organizações do mercado, Ministérios adequados) deveriam encontrar maneira de envolver as organizações de voluntários e as redes informais de cuidadores no novo sistema de saúde e prestação de cuidados.

$\mathrm{Na}$ verdade, o novo pacto da saúde projeta uma nova relação entre Estado e sociedade civil para a produção de um modelo de promoção e prestação de cuidados de saúde em que o Estado se desincumbe da prestação direta e se torna mais permeável aos interesses da indústria, na perspetiva da mundialização da saúde, enquanto os organismos da sociedade civil assumem os cuidados de uma população cada vez mais envelhecida e sujeita a doenças crónicas. No plano individual, a proposta reforça o individualismo como valor moral radical, na medida em que põe, por um lado, nas mãos dos sujeitos individuais e suas famílias a informação e, por outro, a responsabilidade da escolha de estilos de vida mais ou menos saudáveis, repartindo os custos dos cuidados de longa duração com as famílias e comunidades.

A proposta inclui a reorientação das relações de trabalho na área da saúde, considerando-se que "os recursos humanos [são] o maior valor dos cuidados de saúde, mas, em contrapartida, são responsáveis por 60\% das despesas do SNS" (Crisp, 2014: 14). Afirma-se que "práticas há muito realizadas terão de mudar" a partir da "redefinição de funções, com maior flexibilidade das mesmas e ênfase na informação partilhada e no trabalho em equipa" face às 
novas possibilidades criadas tanto pelas parcerias com doentes, como a partir de tecnologias inovadoras (idem: ibidem).

\subsection{Perspetivas sobre o atual processo de empresarialização da Saúde em Portugal}

As entrevistas em profundidade realizadas para esta investigação contribuem para a compreensão das atualizações no pensamento empresarial na área da saúde em Portugal após a publicação das duas obras apresentadas anteriormente. Apesar da riqueza de informações captadas nas entrevistas, e tendo presente o propósito deste artigo, optou-se por destacar as que permitem reforçar os posicionamentos assumidos acerca da empresarialização na área da saúde em Portugal. A esse respeito, atente-se à seguinte passagem:

A forma como se articulam e como são as regras de mercado em Portugal não estão, exatamente, num verdadeiro equilíbrio de mercado, como noutros locais. (...) para já, é difícil aceitar e assumir que a saúde é um verdadeiro mercado, porque nós não temos um produto a funcionar aqui, como no mercado normal. No mercado normal, a oferta induz a procura. Na saúde, em princípio, isso também pode acontecer, mas é o menos desejável, porque o mais desejável era que a oferta fosse condicionada pelas necessidades em saúde e não que condicionasse a procura, como num mercado normal. Isso desvirtua o princípio de mercado, logo à partida. (...) Depois, temos também alguma dificuldade de ajustamento das regras puras de mercado, sobretudo em países como o nosso, em que a criação do Serviço Nacional de Saúde tem quarenta anos (Presidente APDH/ Professora da Escola Nacional de Saúde Pública).

Já o diretor do Programa Inovar em Saúde explicita uma outra abordagem sobre o panorama atual na governação em saúde. Refere que há "uma corrente, em Portugal, que defende que nós deveríamos ter uma coisa que é a produção dos atos de saúde e outra, que é a contratualização dos atos de saúde". Para ele, o Estado não deveria ser, ao mesmo tempo, prestador e pagador: "Deve ficar para o papel de pagador e regulador e deixar a prestação livre - é um conceito liberal do mercado". Ainda na mesma linha, importa diferenciar o SNS e o Sistema Nacional de Saúde, definindo este último pela incorporação de prestadores públicos e privados. O papel dos prestadores privados asseguraria a diversificação da oferta, garantindo melhores e mais confortáveis instalações dos hospitais públicos. Uma diferença apontada é que as estruturas privadas "podem fazer tudo desde o princípio, enquanto nos hospitais [públicos] já existe uma estrutura feita e posso ter funcionários que não são bons, mas tenho que convencê-los a ser melhores, ou ficar com eles como estão". Afirma, ainda, que, nos hospitais privados, "entre a necessidade e a decisão, não há patamares", enquanto, nos hospitais públicos, "os administrados hospitalares inundaram os hospitais” (Diretor do Programa Inovar em Saúde). 
Sobre o papel do setor privado na saúde, a presidente da APDH afirma que "a prestação privada é um caminho que eles estão a tentar impor e eu acho que o mercado deve ser composto de tudo: público, privado e social”. Apresenta uma reflexão sobre as mudanças recentes no quadro epidemiológico e de restrição orçamental estabelecida pelo Estado português e suas implicações para a saúde coletiva, interrogando-se: "Dado que não temos mais dinheiro, tiramos onde? Damos a quem pode comprar adicionalmente, retiramos de outras margens? A que margens é que vamos? Essa é a discussão que fazemos neste momento e não é fácil fazê-la”.

A entrevistada seguinte, vogal da Comissão Diretiva do mestrado em Gestão de Unidades de Saúde da Escola de Economia e Gestão da Universidade do Minho, elabora as suas reflexões a partir do estudo de doutoramento que realizou sobre os modelos de gestão hospitalar em Portugal em 2007, período anterior ao que define como de abertura de portas "para novos modelos, nomeadamente para as parcerias público-privadas”. Segundo a entrevistada:

Em 2007, o modelo que mais avançou foi o modelo EPE, gerido segundo o modelo empresarial. Em termos práticos, o que é que isto significa? (...) Um hospital EPE é uma empresa e, portanto, tem que ser regido segundo as regras comerciais normais de uma empresa. Não é $100 \%$ livre, como uma empresa privada, apenas porque tem capitais públicos, faz parte do Ministério da Saúde e, ao fazer parte, tem que cumprir uma série de requisitos, mas só nesses termos. Se eles quiserem comprar uma máquina qualquer ou um medicamento na farmácia da esquina, alguém que tenha isso nas suas funções vai à farmácia da esquina e compra.

Em relação à contratação dos trabalhadores, no modelo EPE, o concurso público não é obrigatório. A chegada do modelo de gestão empresarial também modificou o perfil dos quadros administrativos, incorporando profissionais formados na área de gestão em detrimento dos médicos, ainda que com especialização em administração. A contratação desses profissionais continua a dar-se por nomeação do Ministério da Saúde. Ainda que, em Portugal, os serviços de saúde sejam maioritariamente prestados por entidades públicas, ou ligadas de alguma maneira ao setor público, são significativas as mudanças em curso:

o que o Estado quer é que seja substituído e que seja comprador de serviços, não fornecedor. Os grupos econômicos aperceberam-se disso e entraram em força na oferta dos cuidados de saúde. Há já bastantes hospitais privados. Aqui, em Braga, neste momento, o mesmo grupo tem dois hospitais privados, só na zona de Braga. Portanto, temos o grupo da Trofa, que tem um hospital privado e que, em maio, abriu no centro da cidade uma outra unidade com toda a oferta que tem no 
outro, a três quilômetros de distância (Vogal da Comissão Diretiva do mestrado em Gestão de Unidades de Saúde).

A tendência apresentada de alteração do papel do Estado de fornecedor para pagador dos serviços de saúde expressa-se fortemente nos termos como se estabeleceram as parcerias público-privadas:

No fundo, o Estado trocou a propriedade dos edifícios, dos equipamentos, por alguém exterior, privado, e, em troca, dá a exploração por quinze a vinte e cinco anos. O privado entra, constrói o hospital, compra os equipamentos, compra tudo que é infraestrutura e, em troca, recebe uma mensalidade do Estado e, ainda, todos os gastos inerentes à atividade que é contratada anualmente através do contrato-programa. E quem gere é o privado. Têm um valor que é concertado todos os anos e, em troca, têm a garantia de fornecer um conjunto de atividades hospitalares a uma zona que foi previamente estabelecida ao nível do Serviço Nacional de Saúde (Vogal da Comissão Diretiva do mestrado em Gestão de Unidades de Saúde).

\section{Notas finais}

Os depoimentos recolhidos no contexto das entrevistas aprofundadas revelam que o que se projetava para o futuro da saúde em Portugal nos documentos analisados vem sendo implementado há, pelo menos, uma década por meio da reconfiguração do papel do Estado. Este tende a "desligar-se” progressivamente da prestação direta e passa a fomentar o avanço da empresarialização da saúde.

A mundialização da saúde tem orientado as políticas de saúde em Portugal para além da contenção de custos e da privatização dos serviços. O Estado tem fomentado a criação de sistemas cuja fronteira entre público e privado vem sendo rompida. O incentivo à corresponsabilidade social estende-se a "todos", desde administradores (sejam eles pessoa física ou jurídica), a trabalhadores e utentes, estes últimos renomeados clientes dos serviços de saúde. A reflexividade social constitui uma premissa para o estímulo do Estado reformado na tentativa de encontrar o conhecimento e a informação que orienta a participação - entendida como colaboração para melhoria dos serviços e do atendimento, em si - e a escolha de estilos de vida saudáveis para prevenção das doenças.

Os problemas de saúde associados ao envelhecimento e à predisposição genética para a doença e a classe social são preocupações centrais quando se discute a sustentabilidade financeira do Estado. Projeta-se que os mesmos poderão ser superáveis através de investimento esclarecido, planeamento de longo prazo e gestão preventiva de risco. Porém, considerando os pilares da mundialização da saúde, fica patente que a governação da mesma tende a reforçar os cidadãos 
com mais recursos financeiros face aos que detêm menores rendimentos económicos. Aqueles são assumidos como "investidores na saúde”, sendo levados a tomar medidas preventivas contra a doença futura, enquanto os desapossados sociais são levados a assumir o papel de autogestão e a realizar melhorias incrementais e de curto prazo nas suas condições de saúde e de vida.

\section{Referências bibliográficas}

AMARAL, Susana, MARQUES, Ana Paula (2014), "Emigração Portuguesa de Profissionais de Saúde: (Di)Visões em torno de um fenómeno emergente", in M. I. Martins, A. P. Marques, N. R. Costa e A. Matos (Orgs.), Trabalbo em Saúde, Desigualdades e Políticas Públicas (E-book), Edição CICS-UMinho/ ENSP/FIOCRUZ, pp. 141-158.

APAH (Associação Portuguesa dos Administradores Hospitalares)/ APDH (Associação Portuguesa para o Desenvolvimento Hospitalar) (2007), O Futuro da Saúde em Portugal, Lisboa, Companhia de Ideias.

BANCO MUNDIAL (1997), O Estado num Mundo em Transformação: Informe obre o desenvolvimento mundial, Washington, D.C., Banco Mundial.

BEZES, Philippe, DUMAZIÈRE, Didier (2011), "Introduction (dossier-débat): New Public Management et Professions dans l'Etat: Au-delà des oppositions, quelles recompositions", Sociologie du Travail, 53, pp. 294-305.

BOLTANSKI, Luc, CHIAPELLO, Eve (1999), Le Nouvel Esprit du Capitalisme, Paris, Gallimard. BOYER, Richard (coord.) (1986), La Flexibilité du Travail en Europe, Paris, La Découverte.

CASTELLS, Manuel (2003), A Era da Informação: Economia, sociedade e cultura, vols. I, II e III, Lisboa, Fundação Calouste Gulbenkian.

CORREIA, Tiago (2012), Medicina: O agir numa saúde em mudança, Lisboa, Mundos Sociais.

CRISP, Lord Nigel (2014), Um Futuro para a Saúde: Todos temos um papel a desempenhar, Lisboa, Fundação Calouste Gulbenkian.

DUBAR, Claude, TRIPIER, Pierre (1998), Sociologie des Professions, Paris, Armand Colin.

EVETTS, Julia (2012), "Sociological Analysis of the New Professionalism: Knowledge and expertise in organizations”, in T. Carvalho, R. Santiago e T. H. Caria (orgs.), Grupos Profissionais, Profissionalismo e Sociedade do Conhecimento, Porto, Afrontamento, pp.13-27.

EVETTS, Julia (2010), “Reconnecting Professional Occupations with Professional Organizations: Risks and opportunities”, in L. Svensson e J. Evetts (ed.), Sociology of Professions: Continental and anglo-saxon traditions, Goteborg, Bokforlaget Daidalos.

FALLEIROS, Ialê, PRONKO, Marcela Alejandra, OLIVEIRA, Maria Teresa Cavalcanti (2010), "Fundamentos Históricos da Formação/ Atuação dos Intelectuais da Nova Pedagogia da Hegemonia", in L. M. W. Neves (Org.), Direita para o Social e Esquerda para o Capital: Intelectuais da nova pedagogia da hegemonia no Brasil, São Paulo, Xamã, pp.39-95.

GIDDENS, Anthony (2001), Terceira Via: Reflexões sobre o impasse político atual e o futuro da social-democracia, Rio de Janeiro, Record.

KULMANN, Ellen (2012), "Professionalism Matters: Unpacking the knowledge-power nexus in healthcare governance”, in T. Carvalho, R. Santiaga e T.H. Caria (orgs.), Grupos Profissionais, Profissionalismo e Sociedade do Conhecimento, Porto, Afrontamento, pp.151-162.

MACEDO, Ana (2006), "A Qualidade na Formação em Contexto Hospitalar: Uma reflexão crítica", in M. Silva e Costa e M. E. Leandro (orgs.), Participação, Saúde e Solidariedade: Riscos e Desafios, Associação Ibero-Americana de Sociologia das Organizações (AISO), Braga, Universidade do Minho, pp.335-346. 
MACEDO, Ana (2002), “O Hospital como Empresa: Representações e opiniões de uma Amostra de Enfermeiros”, Enfermagem, 27/ 28, pp.16-25.

MARQUES, Ana Paula (2014), "Mercados de trabalho no sector da saúde: profissionalismo, paradoxos e dilemas de regulação”, in M. I. Martins, A. P. Marques, N. R. Costa, A. Matos (Orgs.), Trabalho em Saúde, Desigualdades e Políticas Públicas, (Ebook), Edição CICSUMinho/ ENSP/FIOCRUZ, pp.127- 139.

MARQUES, Ana Paula (2009), “'Novas' Legitimidades de Segmentação do Mercado de Trabalho de Jovens Diplomados”, Revista Portuguesa de Educação, 22 (2), pp.85-115.

NEVES, Lúcia M. W. (Org.) (2010), Direita para o Social e Esquerda para o Capital: Intelectuais da nova pedagogia da hegemonia no Brasil, São Paulo, Xamã.

SANTIAGO, Rui, CARVAlHO, Teresa (2012), Grupos Profissionais, Profissionalismo $e$ Sociedade do Conbecimento, Porto, Afrontamento.

SENNETT, Richard (2007), A Cultura do Novo Capitalismo, Viseu, Relógio D’Água.

SILVA, Mariana Vieira (2012), "Políticas Públicas de Saúde: Tendências recentes", Sociologia, Problemas e Práticas, 69, pp. 21-128.

SVENSSON, Lars, EVETTS, Julia (2010), Sociology of Professions: Continental and anglo-saxon traditions, Goteborg, Bokforlaget Daidalos.

Agradecimento especial aos entrevistados pelo tempo disponibilizado no quadro da realização desta pesquisa, nomeadamente, à Presidente da APDH e Professora da Escola Nacional de Saúde Pública, ao Diretor do Programa Inovar em Saúde e à vogal da Comissão Diretiva do mestrado em Gestão de Unidades de Saúde. 
Wieser, Doris; Moreira, Luciana - 0 passado por dentro do presente: Guerra Colonial portuguesa e as remeescritas da memória cultural . Configurações, vol. 19, 2017, pp. 89-103

\title{
0 passado por dentro do presente: Guerra Colonial portuguesa e as reescritas da memória cultural
}

\author{
DORIS WIESER*
}

Universidade de Lisboa

LUCIANA MOREIRA**

Universidade de Coimbra

\section{Resumo}

Este artigo apresenta um estudo sobre a memória cultural (Aleida e Jan Assmann) e pós-memória (Hirsch, Suleiman) da Guerra Colonial Portuguesa na poesia e nas artes visuais. O corpus compreende uma série de poemas escritos pela geração que viveu a guerra em idade adulta de forma direta ou indireta (Manuel Alegre, Fiama Hasse Pais Brandão e José Niza) e obras elaboradas pelas gerações uma e meia e segunda: instalações de Ana Vidigal e uma curta-metragem de António Ferreira. O objetivo da análise prende-se com as estratégias dos artistas de destruir os pilares constitutivos da identidade nacional portuguesa, sepultando mitos nacionais, denunciando estragos emocionais e reivindicando a reescrita da memória cultural do país.

Palavras-chave: guerra colonial, identidade nacional, memória, pós-memória.

\footnotetext{
Abstract

The past inside the present: the Portuguese Colonial War and the rewriting of the cultural memoryl

This article focuses on the cultural memory (Aleida and Jan Assmann) and post-memory (Hirsch, Suleiman) of the Portuguese Colonial War in poetry and visual arts. The empirical support comprises both poems written by the generation that lived the war, directly or indirectly, in its adulthood (Manuel Alegre, Fiama Hasse Pais Brandão and José Niza), as well as artworks elaborated by the one-and-a-half and second "Investigadora FCT do Centro de Estudos Comparatistas da Universidade de Lisboa (CEC). E-mail: dwieser@letras.ulisboa.pt.

** Investigadora no Centro de Estudos Sociais da Universidade de Coimbra (CES). E-mail: lucianamoreira@ces.uc.pt.
} 
generations: installations by Ana Vidigal and a short film by António Ferreira. The goal is to analyse the strategies applied by the artists to destroy the pillars of the Portuguese national identity, burying national myths, denouncing emotional damage and claiming the rewriting of the country's cultural memory.

Keywords: Portuguese Colonial War, national identity, memory, post-memory.

\section{Résumé}

Le passé dans le présent : la guerre coloniale portugaise et les réécritures de la mémoire culturelle

Cet article présente une étude sur la mémoire culturelle (Aleida et Jan Assmann) et la post-mémoire (Hirsch, Suleiman) de la guerre coloniale portugaise dans la poésie et les arts visuels. Le corpus comprend un ensemble de poèmes écrits par la génération qui a vécu la guerre à l'âge adulte de façon directe ou indirecte (Manuel Alegre, Fiama Hasse Pais Brandão et José Niza), ainsi que des ouvrages conçus par les générations un et demi et deuxième : des installations d'Ana Vidigal et un court-métrage d'António Ferreira. L'analyse porte sur les stratégies des artistes pour déconstruire les éléments constitutifs de l'identité nationale portugaise, en enterrant les mythes nationaux, en dénonçant les dommages émotionnels et en réclamant une réécriture de la mémoire culturelle du pays.

Mots-clés : guerre coloniale portugaise, identité nationale, mémoire, post-mémoire.

Quantos desastres dentro de um desastre. Alcácer Quibir foi sempre o passado por dentro do presente ó meu país que nunca te encontraste.

Manuel Alegre, "Explicação de Alcácer Quibir”, 1967

\section{Introdução: Memória cultural e identidade nacional}

A literatura Desde ainda antes do 25 de abril de 1974, centenas de obras literárias têm sido publicadas sobre a Guerra Colonial. Neste panorama, a Antologia da Memória Poética da Guerra Colonial (2011) ${ }^{1}$, organizada por Margarida Calafate Ribeiro e Roberto Vecchi, é um importante compêndio que visa a inscrição de uma seleção significativa de poemas na memória cultural portuguesa. Entretanto, surgiram novas gerações que se debruçam sobre o tema de outra maneira. Autores e autoras que nasceram durante os treze anos de Guerra Colonial e absorveram as tensões psicológicas da época enquanto crianças 
formam o que Susan Suleiman (2002) denominou 1.5 generation e aqueles que nasceram nos anos posteriores à Revolução dos Cravos pertencem à chamada "segunda geração" (Hirsch, 2008). Neste ensaio, analisaremos o modo como autores de diferentes gerações denunciam a Guerra Colonial, atacando e subvertendo elementos da identidade e do imaginário nacional portugueses. Para este efeito, escolhemos poemas de testemunhas da guerra (Manuel Alegre, Fiama Hasse Pais Brandão e José Niza) contidos na mencionada antologia. A pós-memória das gerações seguintes será analisada com base em instalações de Ana Vidigal e numa curta-metragem de António Ferreira.

Jan Assmann distingue dois tipos de memória coletiva: por um lado, a "memória comunicativa" (kommunikatives Gedächtnis), que abarca as vivências das três a quatro gerações vivas (abarcando 80 a 100 anos), e, por outro, a "memória cultural" (kulturelles Gedächtnis), que compreende elementos históricos mais afastados e armazenados exteriormente (ou seja, fora do corpo humano). A memória comunicativa constitui-se na interação informal do quotidiano: pelas histórias, imagens e emoções que se transmitem nas famílias e entre pessoas com contacto direto. Contrariamente a isso, a memória cultural apresenta um maior grau de formalidade (institucional e ritual), depende de entidades e especialistas responsáveis pela sua conservação e é formada na tensão entre poder e resistência. A sua função consiste em unir os indivíduos de uma comunidade através da constante presentificação de uma escolha de elementos de um passado comum. Ela é, portanto, “o passado por dentro do presente" do verso de Manuel Alegre citado na epígrafe. Por isso, a memória cultural armazena elementos constitutivos da identidade tanto individual, como coletiva ou nacional (Assmann, 2007: 48-56). É preciso destacar que a memória cultural visa tanto os modos de lembrança, como os modos de esquecimento. Para capturar esta dinâmica, Aleida Assmann introduziu a distinção entre "memória em função" (Funktionsgedächtnis) e "memória em depósito" (Speichergedächtnis). O primeiro termo designa aqueles elementos do passado que são lembrados numa sociedade através de tradições, ritos, livros escolares, obras canónicas de arte, monumentos, museus, etc.. O segundo termo designa os elementos que, num momento dado, estão fora de uso (dados armazenados em arquivos, bibliotecas, porões de museus, etc.), mas que podem ser resgatados e, assim, aproveitados para reescrever ou completar a memória em função (Assmann, 2006: 54-58).

O modo como uma comunidade recorda o seu passado está intimamente ligado à sua identidade. Portanto, alterações na memória cultural levam inevitavelmente a reajustes na autoimagem da comunidade. Partindo desta premissa, veremos, num primeiro passo, quais eram os elementos constitutivos da identidade nacional portuguesa durante o Estado Novo - os elementos da memória em função - para depois analisar como os poetas da Guerra Colonial os desmistificam e subvertem. 


\section{Elementos constitutivos da identidade nacional portuguesa}

Em Portugal, apesar de as fronteiras geográficas serem das primeiras a definir-se na Europa, a consciência de uma identidade nacional não foi de modo nenhum imediata. De acordo com José Mattoso (1998: 17), há alguns momentos decisivos, na maioria das vezes ligados a episódios bélicos, que foram ajudando à construção de uma noção de identidade nacional entre os portugueses, de entre os quais se podem destacar o movimento de "Reconquista", logo após a independência, ou as lutas fronteiriças entre Portugal e os reinos limítrofes de Leão e Castela. Mais tarde, as lutas pela independência, no período entre D. Fernando e D. João I, mestre de Aviz, terão também um papel fundamental, pressupondo-se até que seja dessa época a criação da lenda do Milagre de Ourique. Posteriormente, a expansão marítima portuguesa e as vitórias que daí advieram acabaram por intensificar uma espécie de orgulho nacional. Os descobrimentos reforçam essa identidade na medida em que o povo português se sente em confronto com a diversidade do outro, o que leva a que, por um lado, sinta uma maior noção de pertença a um grupo ou a uma pátria e, por outro, permite-lhe também elevar-se acima dos povos que está a colonizar, ter a importância que não lhe era atribuída pela Europa, uma vez que, por ela, sempre fora visto com "a distância de quem não é plenamente contemporâneo do espaço-tempo que ocupa” (Santos, 2006: 237).

A expansão portuguesa pelos continentes de África, Ásia e América Latina teve um papel fundamental no cimentar de uma consciência de identidade nacional entre os portugueses, mas os teóricos salvaguardam também o alcance quase elitista dessa consciencialização. José Mattoso (1998: 93), por exemplo, refere haver uma reduzida influência social nas camadas populares como indicador de que estas dificilmente teriam consciência de identidade nacional. Mas os descobrimentos vão levar a que Portugal escape à Europa que o atemoriza e construa um império além-mar, mobilizando, para essa imagem imperial de si próprio, todo o orgulho nacional que se vinha enraizando com bases, por vezes, mais míticas do que históricas. O poder político tenta, portanto, relegar a pequenez do país à memória em depósito e manter os descobrimentos na memória em função.

Um exemplo desse "excesso mítico" em detrimento da análise histórica, ou "défice de realidade" (Santos, 1999: 49), é o da batalha de Alcácer Quibir e da figura do rei D. Sebastião, paradigma de derrota efetiva e de um choque que levou à perda da independência. Ora, esse desastre vai gerar, afinal, uma utopia nacionalista que projeta Portugal como país eleito e sonha o regresso do rei desaparecido para cumprir a missão messiânica de construção de um Quinto Império tão bem delineada pela pena de Padre António Vieira. Com Jan Assmann (2007: 52), podemos chamar a estes elementos míticos "histórias fundacionais" através das quais a comunidade se certifica da sua identidade. 
Para Boaventura de Sousa Santos (2006: 211), foi a incapacidade das classes dirigentes portuguesas que levou a que Portugal adquirisse a posição de um "país semi-periférico no sistema mundial capitalista moderno, desde o século XVII”, mantendo, também devido a essa posição, um papel de intermediação entre o centro e a periferia da economia-mundo, ou seja, entre a Europa e si mesmo e entre si e as colónias que mantinha.

Para piorar o contexto português, em 1890, dá-se o Ultimatum Inglês, que vem trazer outra experiência traumática ao país na medida em que o envergonha face à Europa, retirando-lhe a almejada faixa do Oceano Atlântico até ao Índico através da pretendida união de Angola a Moçambique, demarcada por Portugal no Mapa Cor-de-Rosa. Ao ceder ao Ultimatum, a monarquia portuguesa oferece as condições para um aproveitamento político que levará à revolução republicana. Devido a esse episódio, "poucos períodos da nossa história foram tão 'patrióticos' como aquele que a República inaugurou" (Lourenço, 2009: 31), permanecendo, deste modo, o excesso mítico na noção de identidade nacional de um país que continua consciente da sua grandiosidade (memória em função) e cada vez mais inconsciente da sua condição periférica (memória em depósito). Boaventura de Sousa Santos avança a hipótese de que esta subalternidade económica e política de longa duração faz com que Portugal tenha a experiência de colonizado face a Inglaterra ou à Europa e, por isso mesmo, a "identidade imperial não lhe é outorgada por ninguém para além dele" (Santos, 2006: 229). Assim o colonizador português "é um sujeito tão desprovido de soberania quanto o (seu) colonizado" (idem, ibidem).

O Estado Novo, sob uma máscara de modéstia, vem, através da educação e também da sua máquina de propaganda nacional, criar uma "fabricação sistemática e cara de uma lusitanidade exemplar, cobrindo o presente e o passado escolhido em função da sua mitologia arcaica e reacionária" (Lourenço, 2009: 33). Assim, o Estado Novo resolveu o problema da sua diminuta imagem no presente, dando aos cidadãos a imagem de um país imperial, maior do que a própria Europa se se juntassem os mapas de todas as colónias, como aparecia num livro escolar da época, ensinando que Portugal se prolonga do Minho a Timor. Tal era a grandiosidade do Império projetada e imaginada pelo regime que Margarida Calafate Ribeiro (2004: 15) reconfigura a conceptualização de Boaventura de Sousa Santos sobre o centro e a periferia, redefinindo "o império como imaginação do centro". Assim, a história magnífica da fundação do país até à exemplaridade dos descobrimentos portugueses, uma vez mais, não passava de um império imaginado.

\section{Guerra Colonial e identidade nacional}


A Guerra Colonial portuguesa começa em Angola em 1961, impulsionada por um assalto às prisões e pelos ataques brutais da União dos Povos de Angola (U.P.A.) às fazendas de colonos portugueses no norte do país. Perante aqueles ataques, Oliveira Salazar pronuncia a já mítica frase "Para Angola, rapidamente e em força", demonstrando a "inevitabilidade do conflito armado" (Ribeiro, 2004: 174), uma vez que ao mítico império era impensável assumir o pedido de libertação que se lia nos ataques referidos. Mas aquilo que começa não é e não será nunca uma guerra assumida ${ }^{2}$. Em 1963, processo semelhante inicia-se na Guiné, onde o Partido Africano da Independência da Guiné e Cabo Verde (P.A.I.G.C.) se mostra determinado na libertação, e em 1964 também Moçambique será palco das mesmas tentativas dos guerrilheiros da Frente de Libertação de Moçambique (FRELIMO) que traziam consigo, à luz da ideologia nacionalista de Salazar, o perigo comunista.

Deste modo, tem início um longo conflito bélico que durará de 1961 a 1974, a que apenas a revolução do 25 de abril porá fim, cansados que estavam os militares de ver partir barcos cheios de soldados para lutar numa "guerra sem sentido que o discurso oficial definia como uma missão pacificadora e civilizacional” (Ribeiro, 1998: 130). Assim, Portugal, o primeiro país europeu a lançar-se na aventura marítima, é também o último, depois de um difícil processo que vitimou milhares de soldados portugueses e ainda mais africanos, a deixar cair o seu imperialismo. Foi ao fim de treze anos de Guerra Colonial que se deu "a derrocada abrupta" do império português, após a queda de um regime com quase 50 anos de poder. Nas palavras de Eduardo Lourenço (2009: 46), essa queda deveria ter criado "na nossa consciência um traumatismo profundo" e um "repensamento em profundidade da totalidade da nossa imagem perante nós mesmos e no espelho do mundo", o que, aos olhos do pensador, não terá acontecido.

Se bem que isso seja verdade no que diz respeito à memória política stricto sensu, não podemos afirmar o mesmo em relação à memória cultural em sentido lato. Os processos de transformação da memória cultural - a flutuação de elementos da memória em função à memória em depósito, e vice-versa, e a construção de sentido - são lentos e graduais. Mas sem dúvida que a reescrita da memória cultural no campo da literatura, por oposição a discursos baseados na imperialidade do país e no esquecimento da sua própria subalternidade, bem como a denúncia da Guerra Colonial começaram há muito tempo. Prova disto são os poemas que analisaremos a seguir.

2 Para dar uma pequena prova disso, citamos um discurso de Marcello Caetano proferido na Assembleia Nacional em 27 de novembro de 1968: “Não declarámos guerra a ninguém. Não estamos em guerra com ninguém. A subversão não tem nome e os seus atentados partem não se sabe de quem. Defendemo-nos. Defendemos vidas e haveres. Defendemos, não uma civilização, mas a própria civilização" (Caetano, 1973: 11). 


\section{Memória das testemunhas da Guerra Colonial}

A literatura da Guerra Colonial escrita por quem a viveu, pertencendo, portanto, à geração que fechou o ciclo imperial português, narra a "anti-epopeia pessoal e colectiva que foi a guerra colonial” (Ribeiro, 1998: 139) e, ao mesmo tempo, põe em causa aqueles elementos (míticos) da memória em função que foram aproveitados pelo Estado Novo como justificação e legitimação da guerra. Neste sentido, surge aqui a noção de identidade fragmentada ou perdida e de questionamento da identidade portuguesa na medida em que se regressa perdedor de uma guerra que põe fim ao império português. Muitos dos que combateram, mas também os que foram recebendo apenas os ecos da guerra e que fizeram dela o tema da sua produção poética evocam a consciencialização nacional enraizada em mitos (D. Sebastião, Alcácer Quibir, o mar, os barcos, a bandeira nacional, etc.) de modo a desconstruir esse imaginário fantástico da grandiosidade portuguesa e a marcar a necessidade de Portugal regressar definitivamente das viagens que tinha empreendido. Tais são os casos de Manuel Alegre, Fiama Hasse Pais Brandão e José Niza, analisados de seguida.

Manuel Alegre foi um poeta da guerra no sentido em que tornou seu objeto poético a guerra que experienciou na pele. Quando, em 1962, foi mobilizado para Angola e aí participou numa revolta militar, deu provas do que pensava daquele conflito. Na época, a única coisa que conseguiu foi ser preso pela Polícia Internacional e de Defesa do Estado (P.I.D.E.). Mas a guerra "passou-lhe para os ossos", nas palavras de Fernando Assis Pacheco, outro poeta da guerra, e foi através da escrita que denunciou "a falsa epopeia que era a Guerra Colonial” (Ribeiro, 2004: 225). O poema "Explicação de Alcácer Quibir" (AMPGC, 2011: 343-344), publicado originalmente em O Canto e as Armas (1967), é disso exemplo. Alcácer Quibir é o desastre dos desastres e o poeta evoca a metáfora Alcácer Quibir/Guerra Colonial, para denunciar a previsibilidade da perda desta guerra. Assim, as sucessivas partidas, as sucessivas batalhas, as derrotas logo camufladas em novos sonhos de Quintos Impérios a haver, remetem para as identidades fragmentadas de um povo que pertence a um país que não se olha por dentro, construindo-se a partir de novos mitos regeneradores a cada derrota que vive e que relega, deste modo, à memória em depósito, negando-lhe importância.

Segundo o poeta, "Alcácer Quibir foi sempre/ o ires perder-te em cada Índia que ganhaste" e Índia remete aqui para todas as vitórias que levaram a que o país se dividisse a cada viagem e a cada nova conquista. Trata-se, então, da desconstrução do valor das viagens e da desconstrução da identidade de povo conquistador, pois esse partir constante levou a que se tornasse um povo de identidade fragmentada, incapaz de regressar a si. Alcácer Quibir já não é, para o sujeito poético, um mito regenerador, mas a derrota do próprio país: "as armas vencidas" (que se vão adivinhando na Guerra Colonial), "os ombros vergados”, “as horas perdidas” e, finalmente, "quinhentos anos dentro destes 
anos", ou seja, quinhentos anos de partidas e de batalhas jogados agora numa última guerra, como uma cartada final, desesperada e sem trunfos.

Manuel Alegre evoca "estes barcos que partem com homens e armas/ (...)/ para levar além do mar a guerra”, desconstruindo também esse objecto-símbolo das viagens e de uma grandiosidade imposta. Porque agora os barcos já não partem em busca de novas conquistas, antes partem levando já a morte dentro de si, na medida em que levam os soldados que vão perder a guerra, deixando para trás um Portugal também perdido de si ("E de novo perder/ além do mar o que se deixa em terra”). Alcácer Quibir é, para o poeta, "ir morrer além do mar por coisa nenhuma”, sepultando, de uma vez para sempre, a ideia de Alcácer Quibir enquanto desastre num ciclo de regeneração que colocará Portugal no centro novamente. Por fim, o poeta refere que "um fantasma é rei de Portugal”, remetendo para o fantasma de D. Sebastião, que necessita também de um jazigo definitivo e que não é, portanto, o desejado, mas sim um fantasma que faz "parar o tempo", um louco, precisamente porque não permite que Portugal avance sem o peso desse império que o verga. Mas o fantasma é também o real governador de Portugal, podendo, por isso, ver-se aí uma alusão à loucura de Salazar em manter a Guerra Colonial, forçando a viver um império moribundo.

Concluindo, o poeta faz um uso bem diferente das figuras do imaginário português contidas na memória em função e utilizadas para legitimar o império, quer sejam os barcos, quer seja D. Sebastião, quer seja a própria batalha de Alcácer Quibir, questionando “a instrumentalização da memória nacional feita pelo regime, usando-a, enquanto história e mito, num sentido profundamente diverso daquele que o Estado novo fazia” (Ribeiro, 2004: 226).

No que diz respeito a Fiama Hasse Pais Brandão, ela é das primeiras poetas a dar-se conta do que se passava além-mar. Ela e os colegas dos cadernos Poesia 61 (Gastão Cruz, Luísa Neto Jorge, Maria Teresa Horta, Casimiro de Brito) vão, de um modo muito velado, referir-se às partidas de naus e aos novos significados que o mar assume quando começam a ser enviados navios de soldados no mesmo ano em que saem os cadernos acima referidos.

Em “Barcas Novas” (1967) (AMPGC, 2011: 37-38), escrito a partir de uma barcarola de João Zorro, Brandão parte da imagem das "barcas”, antes usadas por Portugal na expansão e nas rotas comerciais. No poema, as barcas transformam-se em sinal de morte anunciada, pois partem "lavradas de armas", "lavradas de homens" e "levam guerra". A poeta desconstrói, assim, esse símbolo imperial que não é mais, ou não terá sido nunca, sinal de grandeza. Brandão, através de um esquema em paralelismo, acaba por criar trocadilhos velados, mas, na verdade, quer denunciar que o que se colocava no mar não eram mais as barcas - supostamente comerciais, mas, na verdade, desde sempre bélicas -, mas sim as armas em que se haviam transformado aquelas ("Lisboa tem barcas novas/ (...)/ Em Lisboa sobre o mar/ armas novas são 
mandadas”). O “mar” e “as barcas” são aqui reescritos por Brandão de modo a desconstruir a sua simbologia em função de um imaginário nacional. Vistos sempre como fonte de riqueza e engrandecimento do país, passam agora a ser apresentados como modos de chegar a uma guerra não assumida - que, na verdade, não começou apenas em 1961, mas quinhentos anos antes -, como transportes de homens e armas para chegar ao império além-mar e fazer guerra contra o colonizado que pedia libertação.

Em Brandão, esses símbolos de imperialidade e de riquezas são agora apresentados como veículos de chegada a uma guerra imperial mantida em África por um império imaginado quando muitas eram as vozes que se levantavam contra esse conflito e as suas atrocidades e contra o império caduco. O poema de Brandão faz lembrar as palavras de Roberto Vecchi (2010: 33) ao relacionar os conceitos de melancolia e de identidade no caso da poesia da guerra colonial portuguesa: "A escrita da Guerra Colonial é uma escrita melancólica”, já que a autora lhe imprime um tom dolente e saudoso, remetendo para os sentimentos quer de quem fica, quer de quem parte.

José Niza também cumpriu comissão militar em Angola entre 1969 e 1971, durante a qual foi escrevendo alguns poemas que publicou só em 2008 em Poemas de Guerra. O poema “Caro Luiz Vaz" (1970) (AMPGC, 2011: 359) é um misto de piada de caserna, ao gosto sexista e militar, e de denúncia de uma guerra infame. O poema é, como indica o título, uma reescrita de Camões, mais concretamente de alguns versos da Preposição de Os Lusíadas, um texto praticamente indestrutível da memória em função. Mas trata-se de uma apropriação paródica desse texto em que o poeta começa por referir que "canta um ilustre peito lusitano" e rapidamente fica claro que tipo de peito é pela comparação ao da "Mangano", ou seja, ao peito de Silvana Mangano, atriz e modelo italiana com grande projeção na época. Não se trata, portanto, de cantar os ilustres heróis lusitanos, mas a mulher amada que ficou em Portugal. Segue-se um pedido de "engenho e arte" não para louvar as glórias dos portugueses, mas para mandar "esta vil guerra àquela parte". O poeta conclui, sempre fazendo um bem combinado uso do burlesco, dizendo que não tem vocação para "esta guerra injusta/ e sem respeito".

Ora, o que José Niza aqui faz é o enviesamento total do texto de Camões, parodiando a epopeia gloriosa dos portugueses na medida em que desconstrói não só a mensagem de grandiosidade veiculada pela obra, como a própria figura do autor. Com este poema, a grandiloquência de Os Lusíadas é rebaixada ao nível de piada da caserna, retirando ao texto cânone por excelência da literatura portuguesa o seu valor de instrumento de imperialização do espaço português. Mas é também desconstruída a imagem de homem de letras e de armas sempre associada a Camões, pois, neste caso, o sujeito poético não defende esse ideal guerreiro, antes o desconstrói totalmente ao recusar-se veementemente a fazer parte daquela guerra que considera "vil, "injusta" 
e "sem respeito". Pode aqui ler-se, até, que esse desrespeito é tanto para com os portugueses que lutam e morrem numa guerra insana, como para com os colonizados que desde 1961 se batem pela sua libertação (de notar que, quando Niza inicia a sua comissão em Angola, a Guerra já começara há oito anos).

José Niza, ao apoderar-se do cânone português retalhando-lhe o sentido através da paródia, pretende denunciar que "Camões nos tinha cantado como cabeça (da Europa)", mas há muito que não éramos mais do que "o finisterra”. Por isso mesmo, a guerra inútil denunciada no poema era uma tentativa vã de manter uma "realidade de nebulosas heranças imperiais e, ao mesmo tempo, uma abstração que toda a realidade quotidiana negava” (Ribeiro, 2004: 169), principalmente quando se passava dois anos de comissão obrigatória numa guerra movida por ideais em que não se acreditava.

Observamos, nos três poetas, uma forte inclinação para pôr em causa elementos emblemáticos da memória em função, destruindo-os ou exigindo a sua desmitificação. Ao mesmo tempo, eles recordam-nos o não-dito (a memória em depósito), o esquecimento das múltiplas derrotas ao longo da história e o seu significado.

\section{Pós-memória dos filhos da geração da Guerra Colonial}

Para compreender melhor o funcionamento da memória comunicativa de que fala Jan Assmann, é preciso subdividi-la. As três ou quatro gerações vivas não partilham lembranças de uma forma homogênea, havendo uns experienciado na própria pele os acontecimentos traumáticos (primeira geração), outros tendo sido suas testemunhas durante a infância (geração uma e meia) e outros, ainda, tendo nascido após o conflito bélico, sendo herdeiros indiretos das histórias contadas pelos mais velhos (segunda geração e seguintes).

Tendo analisado, no capítulo anterior, poemas da primeira geração, debruçar-nos-emos agora sobre obras artísticas da geração uma e meia (Ana Vidigal) e segunda (António Ferreira). Suleiman (2002) propõe o termo 1.5 generation para falar especificamente de crianças judias sobreviventes do holocausto que sofreram um trauma antes da formação de uma identidade estável associada à idade adulta. O termo é útil para falar também de crianças sobreviventes de outros conflitos bélicos, tendo, contudo, em conta que o impacto psicológico depende muito do local em que se vive. A diferença entre as crianças judias e as crianças portuguesas é que aquelas foram testemunhas diretas de violências múltiplas e estas viveram a Guerra Colonial apenas de forma indireta, visto que acontecia noutro continente e se fazia notar apenas por ausências. Suleiman sublinha que é necessário descrever cada caso na sua particularidade. Isto também inclui uma distinção de três faixas etárias diferentes: (1) crianças de mais ou menos 0-3 anos, demasiado jovens para lembrar; (2) crianças de aproximadamente 4-10 anos, capazes de lembrar, mas demasiado jovens 
para compreender; e (3) crianças de 11-14 anos, capazes já de compreender, mas ainda demasiado jovens para tomar decisões ou serem responsabilizadas pelas decisões que se viram obrigadas a tomar durante o conflito (Suleiman, 2002: 283).

Para Marianne Hirsch (2008) o termo “pós-memória” visa especificamente a relação que a segunda geração estabelece com as experiências traumáticas da primeira, mas acreditamos que também se aplica à primeira faixa etária da geração 1.5 que não tem lembranças próprias da guerra e que, além disso, não partilhou o palco traumático. Estas crianças crescem rodeadas de estórias, imagens e certos comportamentos difíceis de compreender visto que o trauma inscrito no corpo dos pais faz-se notar neles também de maneira não-verbal através de pesadelos, sinais de doença, dores físicas, depressões ou outros transtornos psicológicos. Por essa razão, as obras artísticas desta geração, muitas vezes, procuram representar o efeito de longa duração produzido pela convivência íntima com pessoas traumatizadas, ao mesmo tempo que evidenciam que a memória transmitida no seio da família é sempre mediada por imagens e narrativas que circulam no ambiente público (Hirsch, 2008: 112). Portanto, a pós-memória partilha com a memória direta das testemunhas não só a capacidade de questionar a guerra, mas também de subverter elementos mais antigos da memória cultural. Contudo, expressões de pós-memória acrescentam, muitas vezes, uma componente afetiva diferente: a da difícil convivência com os veteranos da guerra no seio da família, que é também uma preocupação central em Ana Vidigal.

Nascida em 1960, no Porto, Ana Vidigal pertence à segunda faixa etária da geração 1.5. O pai, arquiteto de profissão, foi combatente na Guerra Colonial durante dois anos e meio, de 1967 a 1969, na Guiné. Quando embarcou, Ana ainda não tinha feito sete anos, mas retém memória própria desta época. Para ela, a ausência dos homens nas famílias é uma memória partilhada por praticamente toda a sua geração, como afirma numa entrevista (Ribeiro, 2010). A sua instalação "Penélope" (2000), elaborada para a exposição Um Oceano Inteiro para Nadar, consiste numa cama cujo cobertor é um patchwork dos aerogramas e cartas que os seus pais trocaram entre si durante o serviço militar do pai. Todas as cartas estão dentro dos envelopes envoltos em sacos plásticos e agrafados uns aos outros (Rosengarten e Soares, 2003). Desta maneira, os nomes e endereços dos pais da artista são visíveis, no entanto, o conteúdo das cartas é invisível e fica relegado à intimidade do casal, também representada pela cama, lugar simbólico do amor e do sexo. No entanto, a intimidade encontra-se agora invadida violentamente pela política que defende uma guerra em terras longínquas que continua reclamando para si. A instalação coloca o/a espectador/a na perspetiva da criança que vê a mãe sempre sozinha e angustiada, sentada ou deitada na cama, lendo e relendo as cartas do marido ausente, tal como Penélope esperava Ulisses, denunciando, assim, a 
brutalidade do Estado que separa as famílias e as expõe ao medo da iminência da perda.

Já a instalação "Void" (2007), elaborada para o Project Room da ArteLisboa, desloca o olhar do espectador para o quarto da filha desse homem mobilizado na Guiné (Brito e Dinis, 2009). Encontram-se no quarto uma cama com uma colcha semelhante à de "Penélope", com fotografias agrafadas em patchwork, e uma almofada com uma imagem da artista com uma boina militar, várias fotografias ${ }^{3}$ do pai emolduradas e penduradas na parede, um televisor que mostra um vídeo que o pai da artista filmou na Guiné e uma janela que dá para a imagem do quarto do pai em Nova Lamego. Numa outra parede, ainda há uma série de babetes do irmão mais novo da artista, decoradas com cartas do pai que a mãe lia para os filhos enquanto jantavam (Ribeiro, 2011).

O espaço íntimo da criança está, assim, totalmente invadido por imagens e histórias do pai ausente e da guerra que o tinha levado, não deixando quase lugar para outras histórias próprias e brinquedos adequados à sua idade, salvo poucos livros infantis numa estante. O medo da morte do pai acompanha todos os elementos íntimos da vida familiar, como o jantar e os sonhos noturnos. A artista, ao tornar públicas estas memórias, os aerogramas, as cartas, as fotografias, rompe com a ideia de que estes são assuntos domésticos a permanecer dentro das quatro paredes e denuncia como a guerra também foi das mulheres e das crianças que ficaram. Deste modo, Ana Vidigal desloca a sua denúncia em relação aos/às poetas da primeira geração. Se o alvo da denúncia destes era, sobretudo, a falsidade com que o Estado Novo legitimava a Guerra Colonial, apoiando-se na alegada grandeza imperial de Portugal a despeito de todas as evidências que a contrariavam, o alvo de Vidigal é o estrago emocional desta política ditatorial na vida íntima das pessoas. Neste sentido, as instalações de Vidigal apresentam caraterísticas típicas da sua geração.

Ao contrário de Vidigal, o realizador António Ferreira, nascido em Coimbra em 1970, não tinha idade suficiente durante a guerra para reter lembranças próprias ${ }^{4}$. De facto, a ideia para o seu filme de curta-metragem Deus não quis (2007) não nasceu de vivências próprias, mas da iniciativa do roteirista Miguel Triantafillo (Vieira, 2015). A curta retoma a canção popular "Laurindinha", cantada durante décadas de salazarismo, confrontando-a com imagens fílmicas contrárias.

\footnotetext{
3 Para Hirsch (2008: 107), o uso de fotografias é típico de obras de pós-memória. Não possuindo memória própria, os/as autores/as confrontam-se com a falsa promessa das fotografias de oferecer acesso aos eventos.

$4 \mathrm{O}$ realizador não parece ter feito referências a familiares diretos que tenham vivido a guerra. Invoca, antes, o conflito bélico no Iraque e o apoio de Portugal através da decisão do então primeiro-ministro Durão Barroso como o motivo direto para a criação da curta. Usou o exemplo português da Guerra Colonial para denunciar as injustiças da guerra e as decisões políticas de enviar gente para o perigo constante que é o palco de guerra (Vieira, 2015).
} 
O filme é organizado em dois eixos temporais. O primeiro, muito mais extenso, é composto por vários momentos do ano de 1970 em que um jovem rapaz é chamado à tropa e volta numa cadeira de rodas, portador de deficiência motora. O segundo, composto apenas por breves instantes, mostra o ex-militar no presente, já com cabelo grisalho, ainda sentado na sua cadeira de rodas e vendo fotografias da época (também significativas na obra de Vidigal) no ecrã do seu computador. O filme indica, desta forma, que a história que se desenrola no primeiro eixo temporal é a memória direta de quem a viveu, ao mesmo tempo que coloca os/as espectadores/as na posição de terceiros que recebem a história e as imagens por via de outra pessoa, perspetiva típica da segunda geração e da primeira faixa etária da geração 1.5 .

Uma festa de despedida de soldados, numa taberna do Coentral em 1970, é o momento de convergência de vários elementos significativos do filme. $\mathrm{O}$ jovem soldado dança com a sua namorada e toca-se e canta-se de modo leviano a canção popular "Laurindinha", como se de uma homenagem aos rapazes se tratasse: "Oh Laurindinha, vem à janela./ Ver o teu amor, (ai ai ai) que ele vai p'ra guerra./ Se ele vai p'ra guerra, deixá-lo ir./ Ele é rapaz novo, (ai ai ai) ele torna a vir./ Ele torna a vir, se Deus quiser./ Ainda vem a tempo, (ai ai ai) de arranjar mulher". Na sequência, há vários elementos de grande carga semântica que retomam a letra para depois subvertê-la. A janela é um deles: os namorados tocam o vidro da janela da taberna em jeito de despedida, ele do lado de dentro, ela do lado de fora, depois da festa que anuncia já a rutura e o incontornável afastamento que os vai separar simbolizado pelo vidro. Retoma-se este elemento na despedida dos dois na janela aberta do carro que leva o jovem: a rapariga entrega-lhe uma carta de amor, outro elemento de grande carga semântica que já aparecia nas obras de Vidigal e que simboliza, ao mesmo tempo, proximidade emocional e distância física. Seguem-se cenas em que os namorados, separados geograficamente, escrevem e recebem cartas, enviam-se fotos que se intercalam no filme (originais da época e recriações em que aparece o rapaz).

O ponto de transição da história constitui o momento em que vemos o jovem soldado numa cama de hospital, ferido. Do outro lado do mar, a rapariga lê no seu quarto, sentada na cama, a carta que notifica a lesão de guerra do namorado e esconde-a, finalmente, debaixo da almofada. À semelhança das instalações de Vidigal, o quarto de dormir transforma-se no palco de dramas emocionais originados pela política do Estado Novo; a cama e a almofada tornam-se objetos chave em que se refletem as lesões emocionais. Na cena do regresso do soldado à aldeia, a rapariga corre ao lado do carro em que chega o jovem, contudo, desta vez, o jovem não a olha, nem abre a janela. A rapariga ainda tenta visitá-lo em casa, batendo várias vezes na janela da sala, mas ele recusa vê-la. A janela já não une, separa. A música continua jogando cinicamente com a deficiência motora do jovem que deus não quis que voltasse 
como partiu. Nunca se volta de uma guerra como se parte, trazem-se inscritas nos corpos mazelas emocionais e/ou físicas irreparáveis. Assim, a letra desta canção popular portuguesa, que ocupa um lugar na memória cultural do país até aos dias de hoje, é desconstruída, revelando que a promessa em que tantas Laurindinhas acreditavam ingenuamente não era, na época, mais do que um pérfido instrumento de propaganda política e, paralelamente, um símbolo da alienação social em relação à Guerra Colonial.

\section{Conclusão}

Retomando os conceitos de Jan Assmann e Aleida Assmann, podemos concluir que os poetas da primeira geração, além de condenar a violência da guerra, recorrem a uma estratégia que visa desconstruir os mitos nacionais com que o Estado Novo continuava a justificar a sua presença em África e a Guerra Colonial e que não passavam, afinal, de uma ficção da propaganda nacional. Desta maneira, propõem uma reescrita da memória cultural do país. A sua estratégia visa, em primeiro lugar, a sepultação de alguns significados atribuídos a elementos contidos na memória em função. No entanto, em segundo lugar, também visa, implicitamente, a exumação de elementos silenciados, relegados à memória em depósito, particularmente a memória das derrotas. Esta ação de limpeza da memória cultural proposta pelos poetas, se repetida muitas vezes por muitas vozes, pode acabar por transformar a autoimagem da Nação, sobretudo se for retomada e aceite pela classe política e pelos meios de comunicação social. Se isto já aconteceu ou não, é difícil determinar. Diríamos que é um processo iniciado a ser continuado pelas gerações seguintes.

A geração 1.5 e a segunda geração, pelo menos nos exemplos que escolhemos, parecem ter-se desprendido da mitologia nacional portuguesa. Pelo menos a falsidade da grandiloquência deixa de ser tema das suas obras, optando por subverter outros aspetos que acabaram também por fazer parte de um imaginário coletivo, como a canção popular ou o espaço doméstico como espaço privado e da mulher, por excelência. Assim, a preocupação, agora, são os elementos contidos na memória comunicativa: os estragos emocionais das várias gerações vivas e os traumas com que vivem e que não são reconhecidos pelas novas elites políticas pós 25 de abril que optaram por silenciar o final inglório do imperialismo português. Segundo Eduardo Lourenço (2014: 67), o novo governo expurgou-se da culpa histórica, visto que "[f]oi tudo posto na conta de Salazar. E Salazar na conta de ninguém”. Para o pensador, o desastre da Guerra Colonial "lido às avessas, se converteu no ato fundador da nova democracia portuguesa" (Lourenço, 2014: 68). Portanto, atualmente, a identidade política portuguesa - entendemos "identidade política" como um conceito mais estreito que "identidade nacional" - é fundada sob o silenciamento de um 
“desastre" cujo reconhecimento oficial só aos poucos é reivindicado. Neste sentido, tanto a literatura, como outras artes têm feito um extraordinário trabalho de reescrita da história portuguesa, contribuindo para uma memória cultural mais ampla, como aqui ficou demostrado.

\section{Referências bibliográficas}

ASSMANN, Aleida (2006), Der lange Schatten der Vergangenheit. Erinnerungskultur und Geschichtspolitik, München, C. H. Beck.

ASSMANN, Jan (2007 [1997]), Das kulturelle Gedächtnis. Schrift, Erinnerung und politische Identität in frühen Hochkulturen, München, C. H. Beck.

BRITO, Rui, DINIS, Hugo (coords.) (2009), Ana Vidigal, Lisboa, Galeria 111.

CAETANO, Marcello José das Neves Alves (1973), Razões da presença de Portugal no Ultramar, Lisboa, Oficinas Gráficas da S.E.I.T..

FERREIRA, António (2007), Deus não quis, Argumento de Miguel Triantafillo, Persona Non Grata Pictures, Portugal, 15 min..

HIRSCH, Marianne (2008), “The Generation of Postmemory”, Poetics Today, 29 (1), pp. 103-128.

LOURENÇO, Eduardo (2009 [1978]), O Labirinto da Saudade, Lisboa, Gradiva.

LOURENÇO, Eduardo (2014), Do Colonialismo como Nosso Impensado, Lisboa, Gradiva.

MATTOSO, José (1998), A Identidade Nacional, Lisboa, Gradiva.

RIBEIRO, Anabela Mota (2010), “Ana Vidigal é pintora e nunca lhe passou pela cabeça ter filhos”, Público (12/07/2010), disponível em: https://www.publico.pt/culturaipsilon/noticia/ ana-vidigal-e-pintora-e-nunca-lhe-passou-pela-cabeca-ter-filhos-1446411 [consultado em: 22/02/2016].

RIBEIRO, Margarida Calafate (1998), "Percursos Africanos: A Guerra Colonial na Literatura Pós-25 de Abril”, Portuguese Literary \& Cultural Studies, 1, pp. 125-152.

RIBEIRO, Margarida Calafate (2004), Uma História de Regressos: Império, Guerra Colonial e Pós-Colonialismo, Porto, Afrontamento.

RIBEIRO, Margarida Calafate, VECCHI, Roberto (org.) (2011), Antologia da Memória Poética da Guerra Colonial, Porto, Afrontamento.

SANTOS, Boaventura de Sousa (71999), Pela Mão de Alice: O social e o político na pós-modernidade, Porto, Afrontamento.

SANTOS, Boaventura de Sousa (2006), "Entre Próspero e Caliban: colonialismo, pós-colonialismo e inter-identidade", in Boaventura de Sousa Santos (org.), A Gramática do Tempo: Para uma nova cultura política, Porto, Afrontamento, pp. 211-255.

SULEIMAN, Susan Rubin (2002), "The 1.5 Generation: Thinking About Child Survivors and the Holocaust”, American Imago, 59 (3), pp. 277-295.

VECCHI, Roberto (2010), Excepção Atlântica: Pensar a literatura da Guerra Colonial, Porto, Afrontamento.

ROSENGARTEN, Ruth, OLIVEIRA, Luísa Soares (2003), Ana Vidigal, Lisboa, Assírio \& Alvim.

VIEIRA, João (2015), “Como António Ferreira Aprendeu A 'Respirar (Debaixo D'água)"”, Shifter (29/09/2015), disponível em: http://shifter.pt/2015/09/como-antonio-ferreira-aprendeu-a-respirar-debaixo-dagua/ [consultado em: 22/02/2016]. 
RECENSÕES 
Ribeiro, Fernando Bessa - Fernando Matos Rodrigues, António J. Cerejeira Fontes, Manuel Carlos Silva e André Cerejeira Fontes (coord.) (2016). A Cidade da Participação: Projeto de arquitetura básica participada na Ilha da Bela Vista. Configurações, vol. 19, 2017, pp. 105-108

\section{Fernando Matos Rodrigues, António J. Cerejeira Fontes, Manuel Carlos Silva e André Cerejeira Fontes (coord.) (2016), A Cidade da Participação: Projeto de arquitetura básica participada na Ilha da Bela Vista Porto: Edições Afrontamento}

FERNANDO BESSA RIBEIRO*

Universidade do Minho

O título suscitará, certamente, ao leitor interessado nos problemas urbanos e na democracia, a curiosidade em percorrer o livro para conhecer o modo como uma das questões maiores do nosso tempo é tratada pelos organizadores e autores: o direito à habitação na cidade do Porto. Da responsabilidade de dois colegas de ofício - Fernando Matos Rodrigues e Manuel Carlos Silva - e de dois arquitetos - António e André Cerejeira Fontes -, a construção deste livro contou também com o trabalho de muitas outras pessoas, a saber: Susana Varela, António Fontelas Lopes, Mário Pinto e Ana Ribeiro, da associação de moradores da Bela Vista, Álvaro Siza Vieira, Isabel Raposo, Elena Tarsi, David Leite Viana e Isabel Cristina Carvalho. O prefácio é composto por três textos, cujos autores são Manuel Correia Fernandes e Manuel Pizarro, vereadores da Câmara Municipal do Porto, respetivamente responsáveis pelos pelouros do urbanismo e da habitação e coesão social, e Cláudia da Costa Santos, presidente da Secção Regional Norte da Ordem dos Arquitetos. Os textos que compõem o livro são guiados pela preocupação em discutir a cidade a partir da participação democrática dos que nela habitam, seguidos de um catálogo da autoria do arquiteto António Cerejeira Fontes e de um layout fotográfico de Susana Varela. A edição tem a chancela da Afrontamento que nos oferece,

* Professor Associado do Departamento de Sociologia do Instituto de Ciências Sociais da Universidade do Minho e Investigador Integrado do Centro Interdisciplinar de Ciências Sociais - Polo da Universidade do Minho.E-mail: fbessa@ics.uminho.pt 
uma vez mais, um trabalho irrepreensível, com uma apresentação gráfica que contribui para o deleite do leitor com os textos, desenhos e fotografias.

É um livro sobre um lugar concreto, a ilha da Bela Vista, esteado na participação democrática dos cidadãos que, em negociação com a autarquia e os técnicos, se envolvem numa intervenção arquitetónica nas suas habitações muito degradadas. Construída na segunda metade do século XIX, este aglomerado de habitação popular localiza-se na freguesia do Bonfim, em pleno coração da cidade. Com mais de $90 \%$ das casas que a constituíam em ruína, como assinalam Fernando Matos Rodrigues e António J. Cerejeira Fontes num dos textos do livro ("As ilhas do Porto"), foi elaborado um projeto de arquitetura básica participada pelo Gabinete de Arquitetura Cerejeira Fontes-Imago em parceria com o Laboratório de Habitação Básica para a renovação da ilha. Para os moradores, tratou-se da concretização de um sonho há muito acalentado. António Fontelas Lopes, Mário Pinto e Ana Ribeiro, no texto "Celebrar a habitação na palavra da associação de moradores da Bela Vista”, descrevem em poucas, mas relevantes palavras, o fundado ceticismo de quem foi recorrentemente defraudado pelo poder político, enaltecendo o papel desempenhado pelo "motor" da iniciativa de que este livro é, ao mesmo tempo, testemunho e produto: Fernando Matos Rodrigues.

A democracia é feita também destas iniciativas, envolvendo intelectuais militantes e cidadãos que, em diálogo e cooperação, procuram escrutinar os seus problemas para agir no sentido de os solucionar. É no terreno - neste caso, num bairro degradado da cidade do Porto - que se colocam em prática as perspetivas políticas e as respostas engendradas pelas teorias sociais críticas, decisivas para a construção de uma cidade mais inclusiva, objetivo que trespassa os textos do livro. Exercendo-se deste modo o ofício académico e de cientista social, expõe-se a relevância das ciências sociais. Podemos mesmo dizer que é neste tipo de intervenções que elas encontram boa parte da sua força e sentido, ao contribuírem para interpelar, conhecer e compreender os problemas sociais, lado a lado com os cidadãos - neste caso, os habitantes de um bairro há demasiado tempo ostensivamente esquecido pelo poder político autárquico e pelo próprio governo da República.

Sendo, simultaneamente, um livro de sociologia e antropologia urbana e de arquitetura, ele não deixa de estar vinculado quer a uma antropologia advocacional, quer a uma sociologia pública praticada de forma sistemática e com enorme resiliência por Fernando Matos Rodrigues. Ao longo de mais de dez anos de trabalho de campo com os habitantes da ilha da Bela Vista, empenhou as suas melhores energias e mobilizou os seus alunos na defesa dos interesses legítimos de uma comunidade de cidadãos literalmente abandonados à sua sorte, ao mesmo tempo que discutia com ela os seus problemas e imaginava as melhores soluções para uma intervenção arquitetónica capaz de dar satisfação a muitos dos seus anseios. Ou seja, estamos perante um livro 
implicado, no sentido em que o académico saiu da imaginada "torre de marfim”, tão apreciada pelos que têm, a bem dizer, um entendimento sobranceiro da instituição universitária, recusando "sujar as mãos" com os problemas sociais, mexer neles, agir para os combater. A Cidade da Participação é uma expressão concreta da ciência social engajada (mas também de uma arquitetura comprometida), intervindo no social com os cidadãos, na identificação das injustiças que contribuem para desfigurar a sociedade em que vivemos, incluindo aquelas que se prendem com as questões urbanas, e a procura de respostas habitacionais esteadas na participação e deliberação democráticas, fundamentais para uma vida mais feliz. É isto o direito à cidade! Apesar de negado a uma parte significativa dos cidadãos e famílias do nosso tempo, o seu cumprimento exige o acesso a uma habitação digna. Obrigação constitucional, no artigo $65 .^{\circ}$ da Constituição da República Portuguesa fixa-se que "todos têm direito, para si e para a sua família, a uma habitação de dimensão adequada, em condições de higiene e conforto e que preserve a intimidade pessoal e a privacidade familiar.”

A partir de um caso concreto na cidade do Porto, este livro mostra-nos, pois, que a questão urbana é central nas nossas vidas, dando conteúdo concreto a um conhecido argumento de João Teixeira Lopes, quando nos lembra que a cidade é inseparável dos modos e lógicas de produção e reprodução das sociedades modernas. Longe de ser uma questão nova, ela mereceu uma atenção especial no século XIX por parte de teóricos críticos, com destaque para Friedrich Engels e o seu clássico O Problema da Habitação (1975 [1887]), cujos textos constituintes foram, pela primeira vez, publicados em 1871. Quer isto dizer que a questão urbana era já uma questão social central mesmo quando a larga maioria das pessoas habitava no campo. David Harvey, no seu desafiante livro O Enigma do Capital e as Crises do Capitalismo (2011), alega que a luta de classes no século XIX se fazia também nas cidades, tendo como questão o direito à habitação. Por isso, um dos dois primeiros decretos da Comuna de Paris de 1871 foi, precisamente, sobre uma moratória do pagamento das rendas.

As cidades são espaços privilegiados de ação do capital, nos quais esta procura maximizar por todos os meios a produção de mais-valias que conduzem recorrentemente a situações de colapso súbito dos esquemas creditícios. As consequências estão bem expostas pela última grande crise do capitalismo, em que os créditos especulativos com a habitação das famílias pobres nos Estados Unidos da América jogaram um papel decisivo. Apesar dos enormes avanços na ciência e na técnica, os problemas urbanos continuam a fazer-se sentir, mais graves do que nunca, mostrando que eles são sobretudo políticos e é, pois, com escolhas políticas que os podemos resolver.

Num tempo marcado pelo aumento da população a viver em bairros de lata e outras construções precárias, a cidade permanece um espaço de lutas 
sociais e políticas que nos interessa, sobretudo se estamos comprometidos com um sentido de justiça social e de democracia que não se rende às desigualdades que caracterizam o nosso tempo, nem a formas ambientalmente danosas e até insustentáveis de organização do espaço urbano. Daí que importe encontrar novas respostas para os problemas urbanos a partir do terreno, das condições concretas de habitação dos cidadãos e suas famílias, em diálogo com estes, como muito bem nos revela $A$ Cidade da Participação.

Ilha esquecida, como são ainda muitas outras e muitos bairros da cidade tão bem conhecidos das investigações que muitos sociólogos, antropólogos, arquitetos e até psicólogos sociais têm levado a cabo no Porto, há que destacar o envolvimento do atual governo da cidade. Exprimindo uma rutura com os anos sombrios de Rui Rio, a bem dizer caracterizados por uma guerra contra os pobres, negando-lhes o direito à cidade por via da sua expulsão em benefício de projetos de gentrificação, o atual executivo parece procurar uma outra política, ainda que com alguma tibieza e muitas contradições, em boa medida expressão dos compromissos partidários que o sustentam. Assim, e porque o escrutínio dos seus representantes é direito inalienável dos cidadãos numa democracia, é oportuno realçar o que escrevem neste livro dois vereadores da cidade, Manuel Correia Fernandes e Manuel Pizarro. Se Correia Fernandes assinala a relevância da intervenção na ilha da Bela Vista, nomeadamente por constituir a primeira reabilitação completa deste tipo de aglomerado urbano no Porto, já Manuel Pizarro convoca a atenção do leitor para as carências que ainda se fazem sentir no domínio da habitação na cidade.

Em jeito de memória futura, este livro não deixa de se constituir como referência e controlo da ação política presente e projetada dos responsáveis do governo da cidade no campo da habitação e do urbanismo. E os problemas são muitos: aos velhos, aos de sempre, relacionados com a pobreza e os escassos rendimentos de muitos dos cidadãos do Porto e, por outro lado, com a sempre presente especulação mercantil em torno de terrenos e habitações, junta-se hoje a massificação do turismo. Apesar de estimular muitas oportunidades para a cidade e para quem nela trabalha, é uma ameaça séria às populações carenciadas do centro urbano. Se deixada ao livre-arbítrio do mercado, já sabemos como a história irá, mais uma vez, acabar. Assim, um governo local progressista, comprometido com a construção de uma cidade para todos e não apenas para os privilegiados produzidos pelo dinheiro ou pela herança, terá de definir uma política de cidade e de habitação que, deixando o mercado funcionar, esteja determinada a condicioná-lo e, se necessário, a limitar a liberdade de alguns em prol da liberdade da maioria, a bem dizer dos que estão em baixo, parafraseando Manuel Carlos Silva na sua crítica às teses de Amartya Sen. 